\title{
Energy Use and Carbon Emissions: Non-OECD Countries
}

\section{December 1994}

Energy Information Administration

Office of Energy Markets and End Use

U.S. Department of Energy

Washington, DC 20585 


\section{Contacts}

Energy Use and Carbon Emissions: Non-OECD Countries was prepared by the Energy Information Administration (EIA), Office of Energy Markets and End Use (EMEU). General questions concerning the content of the report may be referred to W. Calvin Kilgore (202-586-1617), Director of EMEU; Mark Rodekohr (202-586-1130), Director of Energy Markets and Contingency Information Division; or Derriel Cato (202-586-6574), Chief of the Short-Term Forecasting and Contingency Branch. Detailed questions may be addressed to Erik Kreil (202-586-6573) or Lowell Feld (202-586-9502). 


\section{DISCLAIMER}

This report was prepared as an account of work sponsored by an agency of the United States Government. Neither the United States Government nor any agency thereof, nor any of their employees, make any warranty, express or implied, or assumes any legal liability or responsibility for the accuracy, completeness, or usefulness of any information, apparatus, product, or process disclosed, or represents that its use would not infringe privately owned rights. Reference herein to any specific commercial product, process, or service by trade name, trademark, manufacturer, or otherwise does not necessarily constitute or imply its endorsement, recommendation, or favoring by the United States Government or any agency thereof. The views and opinions of authors expressed herein do not necessarily state or reflect those of the United States Government or any agency thereof. 


\section{DISCLAIMER}

Portions of this document may be illegible in electronic image products. Images are produced from the best available original document. 


\section{Preface}

The original study, upon which this report is based, was undertaken in response to a request by U.S. Representative Philip R. Sharp, Chairman of the U.S House of Representatives Subcommittee on Energy and Power. Congressman Sharp's request sought a review of international energy and economic data, comparing energy use patterns across countries and in the context of major energy end-use sectors. The purpose of the review was to identify differences in energy use patterns which could be suggestive of opportunities both to economize on the use of fossil fuel energy (i.e., oil, natural gas, and coal) and to reduce greenhouse gas emissions. In April 1994, the first part of this review (Energy Use and Carbon Emissions: Some International Comparisons (DOE/EIA-0579)) was released by the Energy Information Administration (EIA). The report represented a broad review of international data with particular emphasis on the developed countries of the Organization for Economic Cooperation and Development (OECD). This current report, Energy Use and Carbon Emissions: Non-OECD Countries, embodies a similar review, with emphasis on the non-OECD countries (defined to include the developing countries as well as the current and former centrally planned economies).

\section{Abbreviations and Acronyms}

In order to avoid repetition, some of the terms in this report were abbreviated. A list was designed to assist the reader in defining the abbreviations and acronyms. For a quick reference while reading this report, simply open the fold-out sheet on page 61 . 


\section{Contents}

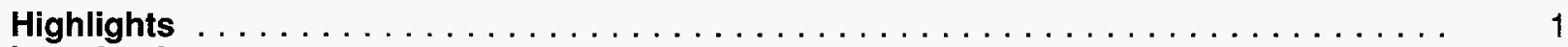

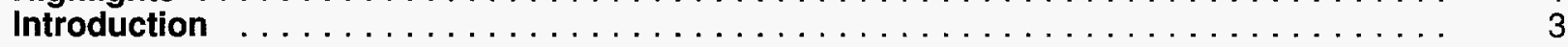

Non-OECD in a World Context $\ldots \ldots \ldots \ldots \ldots \ldots \ldots \ldots \ldots \ldots \ldots \ldots$

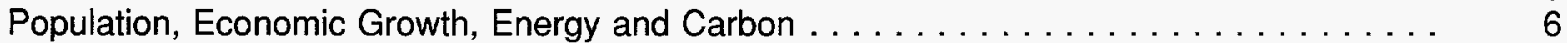

Electricity, GDP, Energy Consumption, Carbon Emissions: OECD vs. Non-OECD $\ldots \ldots \ldots 7$

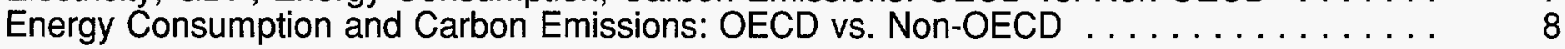

Non-OECD Regional Comparison $\ldots \ldots \ldots \ldots \ldots \ldots \ldots \ldots \ldots \ldots \ldots \ldots \ldots$

Population, Economic Growth, Energy and Carbon $\ldots \ldots \ldots \ldots \ldots \ldots \ldots \ldots \ldots \ldots \ldots$

Energy Consumption by Region $\ldots \ldots \ldots \ldots \ldots \ldots \ldots \ldots \ldots \ldots \ldots \ldots \ldots \ldots \ldots \ldots$

Energy Consumption by Fuel Type; Energy-Related Carbon Emissions $\ldots \ldots \ldots \ldots \ldots \ldots \ldots$. 12

GDP and Energy Consumption per Capita $\ldots \ldots \ldots \ldots \ldots \ldots \ldots \ldots \ldots \ldots \ldots \ldots \ldots \ldots \ldots$

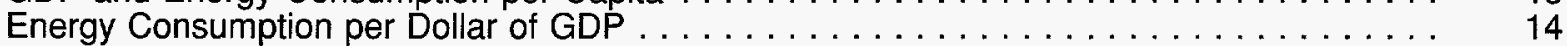

Energy Use and Carbon Emissions: Non-OECD Rankings, $1992 \ldots \ldots \ldots \ldots \ldots \ldots \ldots \ldots$

Regional Energy Consumption by Sector; Fossil Fuel and Total Energy Consumption . . . . 16

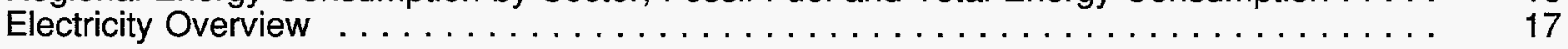

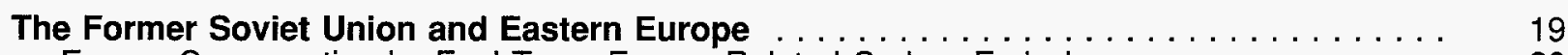

Energy Consumption by Fuel Type; Energy-Related Carbon Emissions $\ldots \ldots \ldots \ldots \ldots \ldots .20$

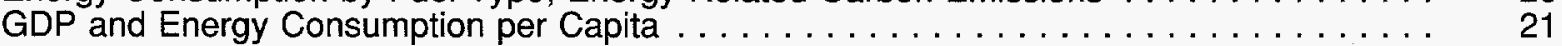

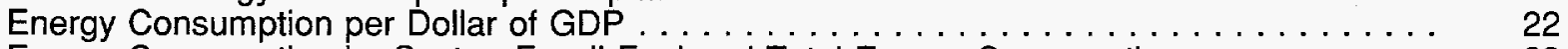

Energy Consumption by Sector; Fossil Fuel and Total Energy Consumption $\ldots \ldots \ldots \ldots .23$

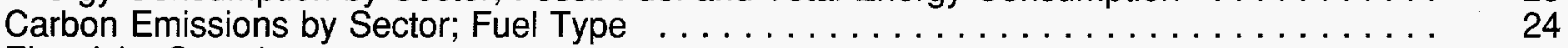

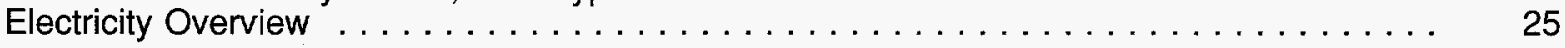

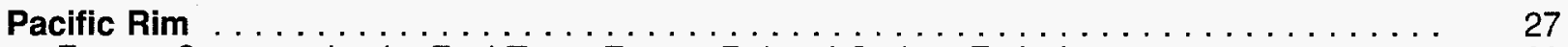

Energy Consumption by Fuel Type; Energy-Related Carbon Emissions $\ldots \ldots \ldots \ldots \ldots .28$

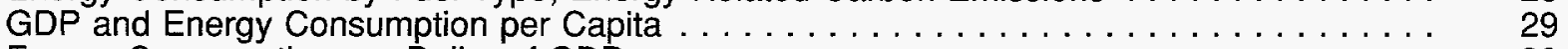

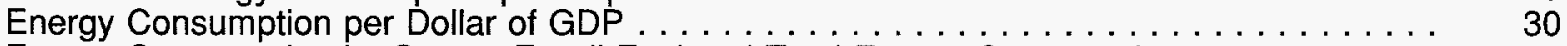

Energy Consumption by Sector; Fossil Fuel and Total Energy Consumption $\ldots \ldots \ldots \ldots . \quad 31$

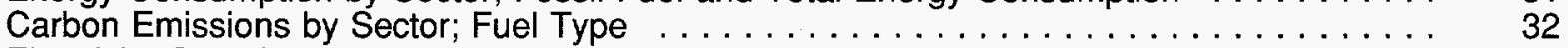

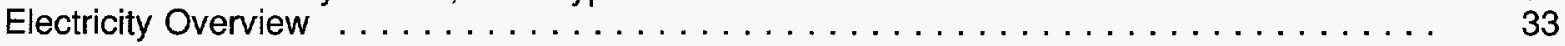

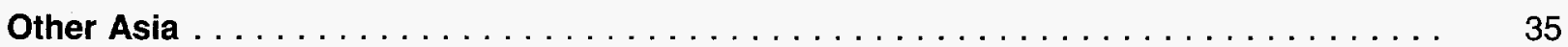

Energy Consumption by Fuel Type; Energy-Related Carbon Emissions $\ldots \ldots \ldots \ldots \ldots \ldots .36$

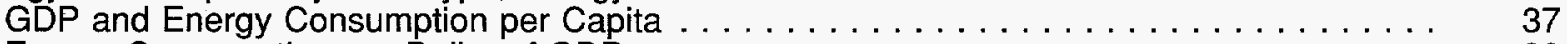

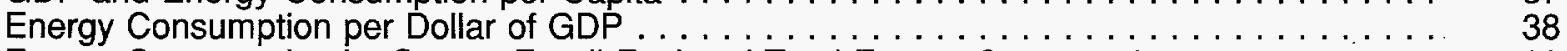

Energy Consumption by Sector; Fossil Fuel and Total Energy Consumption . . . . . . . 39

Carbon Emissions by Sector; Fuel Type $\ldots \ldots \ldots \ldots \ldots \ldots \ldots \ldots \ldots \ldots \ldots \ldots . \ldots \ldots$

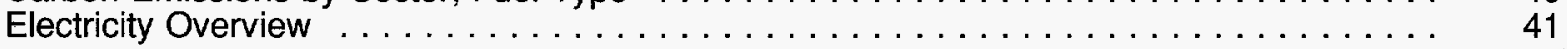

Latin America $\ldots \ldots \ldots \ldots \ldots \ldots \ldots \ldots \ldots \ldots \ldots \ldots \ldots \ldots \ldots \ldots$

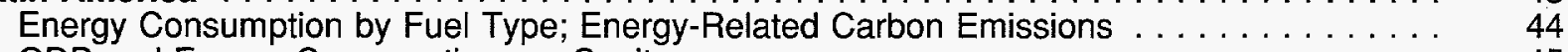

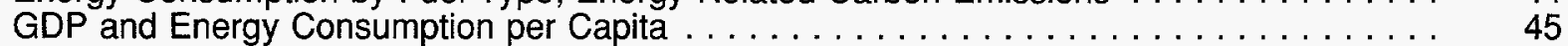

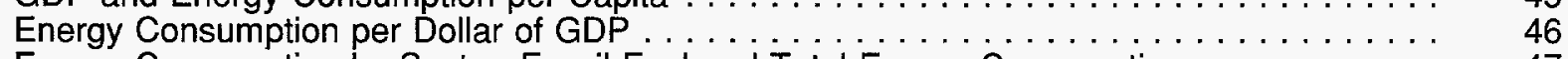

Energy Consumption by Sector; Fossil Fuel and Total Energy Consumption $\ldots \ldots \ldots \ldots .47$

Carbon Emissions by Sector; Fuel Type $\ldots \ldots \ldots \ldots \ldots \ldots \ldots \ldots \ldots \ldots \ldots \ldots \ldots$

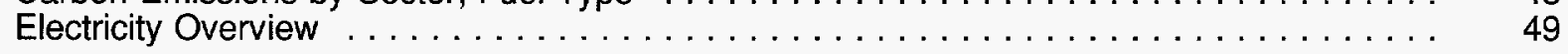

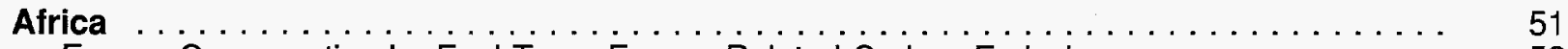

Energy Consumption by Fuel Type; Energy-Related Carbon Emissions $\ldots \ldots \ldots \ldots \ldots \ldots . \quad 52$

GDP and Energy Consumption per Capita $\ldots \ldots \ldots \ldots \ldots \ldots \ldots \ldots \ldots \ldots \ldots \ldots \ldots \ldots$

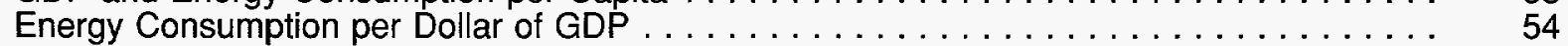

Energy Consumption by Sector; Fossil Fuel and Total Energy Consumption $\ldots \ldots \ldots \ldots \ldots$

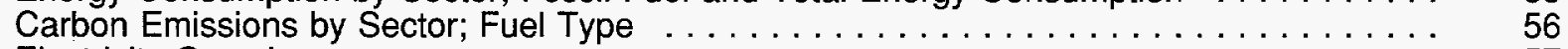

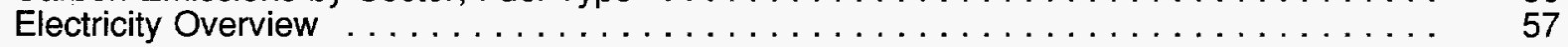

Appendix

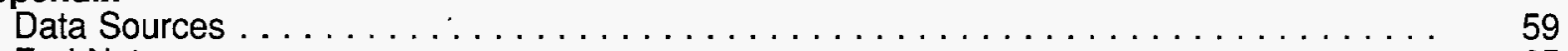

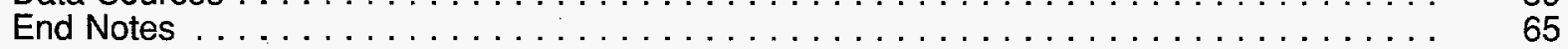

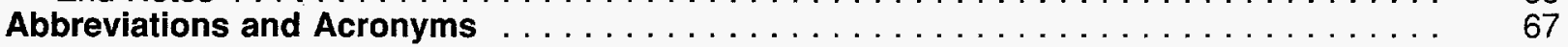




\section{Highlights}

This report surveys world energy use and carbon emissions patterns, with particular emphasis on the nonOECD countries (including the current and former centrally planned economies). The non-OECD is important not only because it currently makes up 84 percent of world population, but because its energy consumption, carbon emissions, population, and gross domestic product (GDP) have all been growing faster (for the past 20 years) than the OECD's. This presentation is divided into seven major sections: Section 1 provides an overview of key trends in non-OECD energy use and carbon emissions since 1970, placing the non-OECD in a world context; Section 2 compares and contrasts energy use and carbon emissions patterns for five major non-OECD regions: 1) former Soviet Union (FSU) and Eastern Europe; 2) Pacific Rim (including China); 3) Latin America; 4) Other Asia (including South Asia and the Middle East); 5) Africa (including South Africa); Sections 3-7 present aggregate and sectoral energy use and carbon emissions data for countries within each of these five regions.

Key conclusions of this study include:

As of 1992, the non-OECD accounted for about half of world energy consumption and carbon emissions. In that year, total world energy consumption was 344 quadrillion Btu, with the OECD consuming 181 quadrillion Btu and the non-OECD 163 quadrillion Btu. World carbon emissions in 1992 were about 6 billion metric tons---51 percent accounted for by the non-OECD and 49 percent, by the OECD.

$\checkmark$ Energy consumption and carbon emissions grew fastest in the non-OECD countries. Non-OECD energy consumption grew 121 percent between 1970 and 1992, while OECD energy consumption increased only 36 percent. During the same period, carbon emissions grew 99 percent in the nonOECD, compared to a 24 percent growth in the OECD countries.

$\checkmark$ Population and economic growth are greatest in non-OECD areas. Between 1970 and 1992, population grew 55 percent (from about 3 billion to nearly 4.6 billion) in the non-OECD, compared to a 21 percent growth in the OECD (from about 710 million in 1970 to more than 860 million in 1992). During the same period, economic output expanded 90 percent in the non-OECD (compared to an 83-percent expansion in the OECD).

$\checkmark$ Within the non-OECD, energy use patterns varied widely. Energy use per capita, for example, was more than ten times as high in the FSU and Eastern Europe than in Africa in 1992. Such differences within the non-OECD are due largely to varying levels of economic development, which affect industrial output, automobile ownership, and electricity penetration.

$\checkmark \quad$ Per capita energy use rose 36 percent in non-OECD areas between 1970 and 1992 with wide variations among countries. Energy consumption per capita in newly industrialized countries such as Taiwan and South Korea quadrupled during the period, nearing levels normally seen in European OECD countries. In contrast, India and China (two of the largest non-OECD countries), although doubling their energy consumption per capita between 1970 and 1992, continued to consume far less energy per capita than the OECD.

$\checkmark$ Regional energy intensity trends contrasted markedly between the non-OECD Pacific Rim and the rest of the non-OECD. In the Pacific Rim (as in the OECD), energy consumption per dollar of output declined sharply and steadily during the period. In all other non-OECD regions, energy intensity increased during the period. 
$\checkmark \quad$ The non-OECD increasingly used more energy and emitted more carbon per dollar of GDP than the OECD between 1970 and 1992. Between 1970 and 1992, OECD energy use per dollar of GDP declined significantly, while in the non-OECD, energy use overall increased as fast or faster, than economic growth. As a result, by 1992 the OECD produced a unit of economic output using little more than half the energy required by the non-OECD countries.

$\checkmark \quad$ In the non-OECD countries, noncarbon-emitting energy sources grew from 4 percent in 1970 to 9 percent of total energy supply in 1992. Noncarbon-emitting energy sources grew even more rapidly in the OECD countries, increasing their share from 7 percent in 1970 to 16 percent in 1992. Most of this increase (in both regions) was due to growth in nuclear power generation.

$\checkmark \quad$ Electricity consumption in the non-OECD countries more than tripled between 1971 and 1990, while overall energy consumption doubled. Most of the growth in non-OECD electric generating capacity involved increased use of fossil fuels, although nuclear and hydroelectric power expanded as well.

$\checkmark$ Several countries, notably China and the former Soviet Union (which was disbanded at the end of 1991), accounted for the vast majority of non-OECD energy consumption and carbon emissions. In 1992, for example, ten countries (including the former Soviet Union, China, India, South Africa, Poland, Mexico, South Korea, Brazil, Saudi Arabia, and Iran) accounted for three quarters of non-OECD energy consumption and carbon emissions. The FSU and China alone accounted for half of non-OECD energy consumption and carbon emissions.

$\checkmark \quad$ The non-OECD countries nearly doubled their carbon emissions between 1970 and 1992. The ten largest non-OECD carbon emitters emitted 2,294 million metric tons of carbon in 1992, a 98 percent increased versus 1970 . The remaining non-OECD countries also doubled their carbon emissions between 1970 and 1992 to 738 million metric tons. 


\title{
Introduction
}

\author{
Energy Use and Carbon Emissions: \\ Non-OECD Countries
}

This report examines international energy use patterns, trends, and energy-related carbon emissions since 1970. The main focus of this study is on the countries outside the Organization for Economic Cooperation and Development (OECD) and on commercial ${ }^{l}$ (oil, gas, coal, electricity) energy.

Background: Economic Growth, In recent years, there has been a growing level of concern Energy Consumption and the that anthropogenic (i.e., caused by human activities) Environment emissions of carbon dioxide and other "greenhouse gases" are contributing to global warming. (Greenhouse gases also include: methane; nitrous oxide; chlorofluorocarbons and related compounds; non-methane volatile organic compounds; and water vapor. ${ }^{2}$ ) As a result of this concern, interest has risen regarding possible costeffective options to help reduce greenhouse gas emissions. Interest has focused primarily on limiting the burning of fossil fuels, which releases carbon (mainly in the form of carbon dioxide) into the atmosphere. One of the most frequently mentioned options in this regard has been reducing the amount of energy needed to produce a given unit of economic output. This option is seen by many as offering the potential for stabilizing (or even reducing) carbon emissions without sacrificing economic growth. A similar consequence could be achieved by substituting low carbon fuels (such as natural gas) for high carbon fuels (coal, for example), or noncarbon-emitting fuels (such as hydroelectric, nuclear, or solar) for fossil fuels.

Energy use and economic welfare are closely intertwined. More developed economies use more energy per capita than those which are relatively less developed. The process of economic development entails increasing levels of consumption of commercially-produced energy. However, historical experience demonstrates that the relationship between economic growth and energy use is not fixed. Nations experiencing similar paths of economic expansion may exhibit significant differences in energy use growth rates. Moreover, nations with similar levels of economic output per capita vary widely in per capita energy consumption. Additionally, nations with similar levels of energy consumption may have significantly different rates of carbon emissions. Examining historical variations in energy use growth rates and differences in international energy use patterns indicates that there is long run flexibility in the relationship between energy consumption, economic activity, and carbon emissions.

Energy Use and Carbon Emissions The first part of this study, Energy Use and Carbon Emissions: Some International Comparisons (DOE/EIA0579), compared energy use patterns between $\mathrm{OECD}^{3}$ and non-OECD countries. The study found large differences between the two groups in growth rates for energy usage, carbon emissions, GDP and population. For example, non-OECD energy demand grew far faster than OECD demand between 1970 and 1992, more than doubling over the period. As a result, the non-OECD share of world energy demand grew rapidly, and would have surpassed the OECD share were it not for the disintegration of the Soviet Union and the resulting downturns in economic output and energy consumption in those countries during the late 1980's and early 1990's.

Similarly, Energy Use and Carbon Emissions: Some International Comparisons found that carbon emissions grew fastest in the non-OECD countries between 1970 and 1992. Non-OECD carbon emissions grew nearly 100 percent during the period---about four times as fast as in the OECD countries. As a result, non-OECD carbon emissions increased from 39 percent of world emissions in 1970 to 51 percent, in 1992. 
Economic expansion and population growth in the non-OECD countries were the two key factors fueling this rapid growth in energy consumption and carbon emissions. Between 1970 and 1992, non-OECD energy consumption grew slightly faster than GDP, and about twice as fast as population. This contrasts sharply with the experience of the OECD countries, where GDP grew much faster than energy consumption and population. In both groups, carbon emissions grew more slowly than either energy consumption or GDP, although growth rates varied by country.

These findings in Energy Use and Carbon Emissions: Some International Comparisons highlighted the critical importance of the non-OECD countries. This report, Energy Use and Carbon Emissions: Non$O E C D$ Countries, builds on the earlier study and more closely examines trends within individual nonOECD regions. This is not meant to diminish the continued importance of the OECD in the continuing effort to reach consensus on a path for sustainable development.

The study is organized, as follows: 1) the non-OECD is placed in a world context; 2) comparison is made between non-OECD regions; 3) aggregate and sectoral energy and carbon emissions data are broken out for individual countries within the major non-OECD regions.

\section{Data Sources}

Energy data used in this report were gathered primarily from three main sources: 1) the Energy Information Administration's International Energy Annual 1992; 2) the OECD's Energy Balances of Non-OECD Countries; and 3) the OECD's Energy Balances of OECD Countries. Economic and population information were taken mainly from: 1) The WEFA (formerly Wharton Econometric Forecasting Associates) Group's World Economic Service: Historical Data, July 1993; 2) The WEFA Group's Ranking of the World's Economies by Size March 1994; 3) the World Bank's World Tables 1992; 4) the International Monetary Fund's International Financial Statistics Yearbook 1992; and 5) the Central Intelligence Agency's The World Factbook 1993. More detailed sources for all graphs are included in the appendix of this report. ${ }^{5}$ All Gross Domestic Product ${ }^{6}$, or GDP, statistics are expressed in 1985 U.S. dollars, calculated on a standard exchange-rate basis. All electricity data are expressed on a primary (not net consumption) basis, taking into account the fuel used in generating the electricity, unless otherwise noted. All sectoral data are expressed on a primary basis as well, and include all inputs used to generate electricity consumed in each sector. Carbon emissions are not equivalent to carbon dioxide emissions ${ }^{7}$. 


\section{Non-OECD in a World Context}

The purpose of this section is to place the non-OECD in a world context with regard to such indicators as: economic output; energy consumption; and energy-related carbon emissions.

Key findings of this section include:

$\checkmark \quad$ The non-OECD consumed 163 quadrillion Btu of energy in 1992, including 59 quadrillion Btu of oil, 37 quadrillion Btu of natural gas, 51 quadrillion Btu of coal, and 17 quadrillion Btu of nuclear/hydro. In the same year, the OECD consumed 181 quadrillion Btu of energy, including 78 quadrillion Btu of oil, 37 quadrillion Btu of natural gas, 37 quadrillion Btu of coal, and 29 quadrillion Btu of nuclear/hydro.

$\checkmark \quad$ Energy consumption and carbon emissions grew faster in the non-OECD than in the OECD between 1970 and 1992. Non-OECD energy demand and carbon emissions grew 121 percent and 99 percent between 1970 and 1992, compared to 36 percent and 24 percent in the OECD.

$\checkmark \quad$ Faster growth in the non-OECD was fueled by rapidly expanding populations and economies. Non-OECD population grew 55 percent between 1970 and 1992, compared to 21 percent in the OECD. Similarly, non-OECD GDP grew 90 percent versus an 83 percent growth in the OECD.

$\checkmark \quad$ As a result of more rapid growth in non-OECD energy demand between 1970 and 1992, the non-OECD share of world energy demand grew rapidly. Were it not for the collapse of communism in the FSU and Eastern Europe region, which resulted in sharp downturns in economic output and energy consumption in that region, the non-OECD share of world energy demand likely would have surpassed the OECD share during the early 1990's.

$\checkmark \quad$ The non-OECD share of world carbon emissions also grew rapidly during the period. Whereas in 1970 the non-OECD accounted for 39 percent of world carbon emissions, by the mid-1980's it surpassed 50 percent. In 1992, the non-OECD emitted 51 percent of world carbon emissions.

$\checkmark \quad$ The ten non-OECD countries with the largest carbon emissions accounted for 38 percent of world carbon emissions and 35 percent of world energy consumption in 1992. These ten countries (the FSU, China, India, South Africa, Poland, Mexico, South Korea, Brazil, Saudi Arabia and Iran) emitted 2,294 million metric tons of carbon in 1992. This compares to U.S. emissions of 1,345 million metric tons, and Group of Seven (G-7) emissions of 2,470 million metric tons.

$\checkmark \quad$ The top ten non-OECD carbon emitters also accounted for most of the growth in non-OECD carbon emissions between 1970 and 1992. Carbon emissions from these ten countries increased 98 percent between 1970 and 1992, accounting for 75 percent of the growth in non-OECD carbon emissions during that period.

$\checkmark \quad$ Electricity consumption grew rapidly throughout the world between 1970 and 1992, particularly in the non-OECD. Although OECD electricity consumption grew rapidly, more than doubling between 1970 and 1992, in the non-OECD it grew even faster, more than tripling during the period. 


\section{Population, Economic Growth, Energy and Carbon}
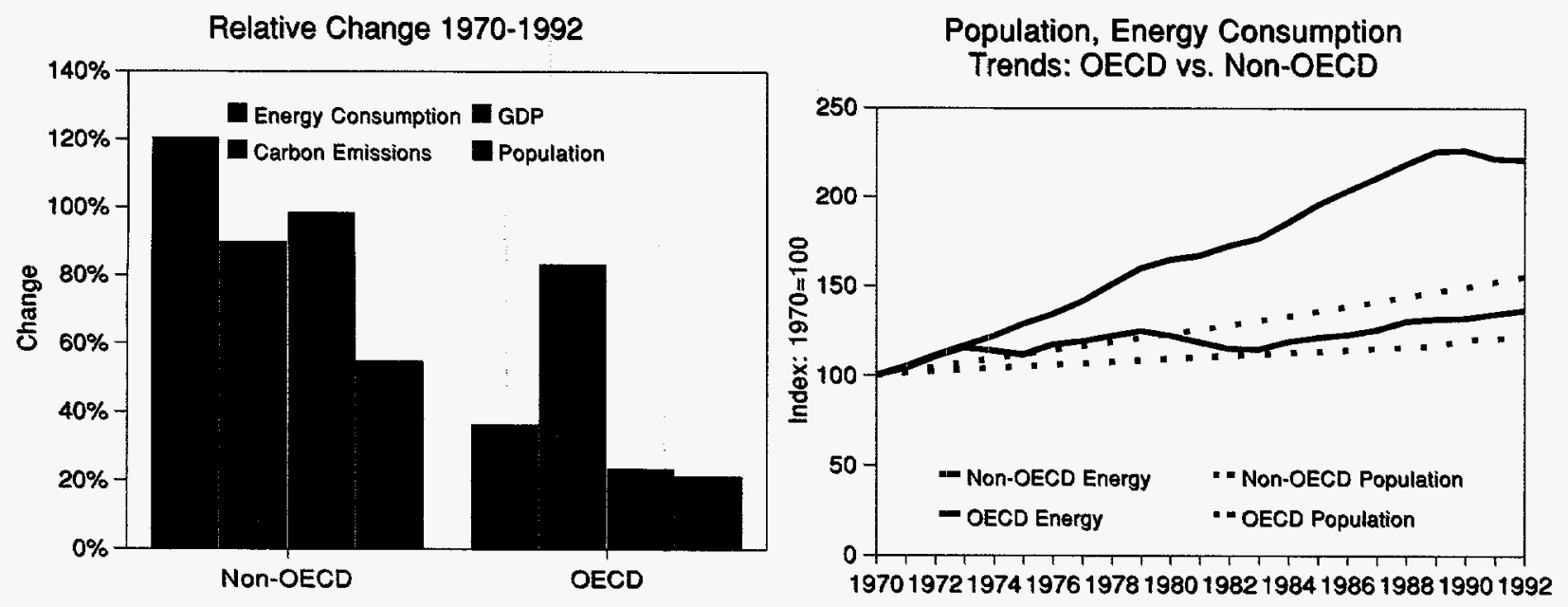

Source: See Appendix p. 53.

$\checkmark$ Growth in energy demand (and energy-related carbon emissions) is driven by two main forces--economic growth and population increases. Both of which, historically, have tended to increase demands on many resources, including energy.

$\checkmark$ Growth patterns in the non-OECD have differed markedly from those in the OECD. Rates of increase in energy use, carbon emissions and population have been 2 to 4 times greater than in the OECD.

$\checkmark$ Carbon emissions grew nearly twice as fast as the population in the non-OECD between 1970 and 1992, but only slightly faster than population in the OECD during that period.

As a result of a more rapid growth in world energy demand relative to population between 1970 and 1992, the amount of energy consumed per capita, worldwide, increased by 13 percent, from 56 to 62 million Btu per person per year. The largest increases were in non-OECD areas. Nonetheless, as of 1992, the OECD consumed approximately seven times more energy per person than the nonOECD (209 million Btu vs. 30 million Btu per person).

As of 1992, the world population stood at about 5.5 billion, with the OECD accounting for 860 million and the non-OECD for 4.6 billion. 


\section{Electricity, GDP, Energy Consumption, Carbon Emissions: OECD vs. Non-OECD}

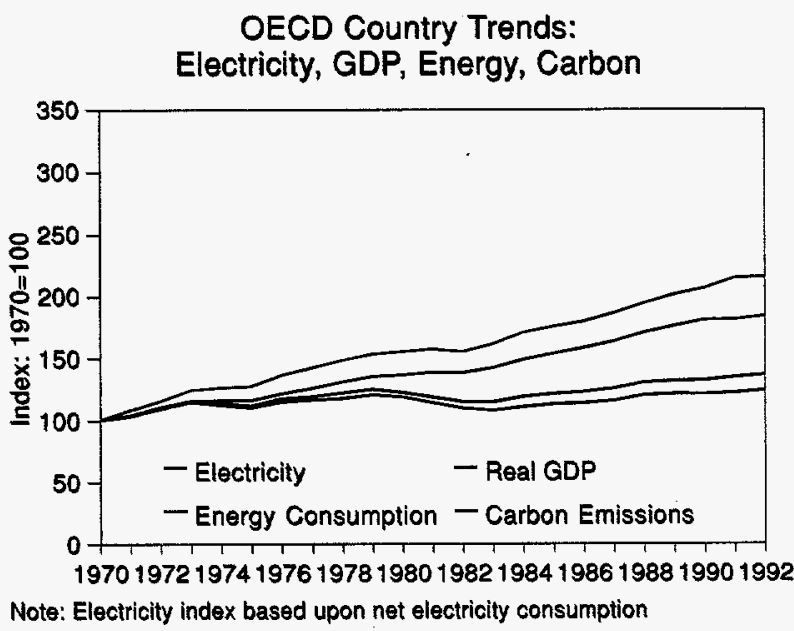

OECD Country Trends: Electricity, GDP, Energy, Carbon

Source: See Appendix p. 53.

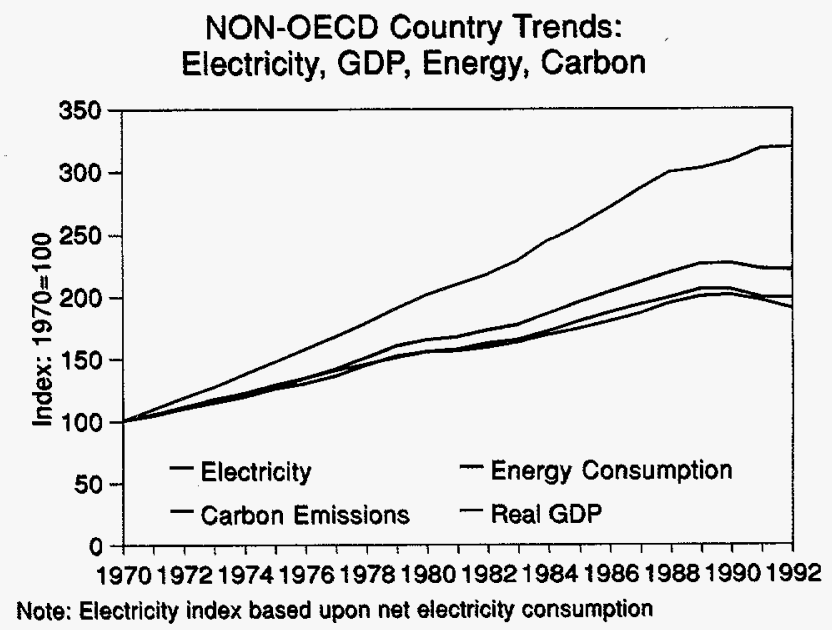

NON-OECD Country Trends: Electricity, GDP, Energy, Carbon

$\checkmark$ The figures, above, compare changes between 1970 and 1992 in: 1) electricity consumption; 2) real GDP (in constant 1985 U.S. dollars, measured on an exchange-rate basis); 3) energy consumption; and 4) energy-related carbon emissions for the OECD and non-OECD countries using an index based on 1970 levels for each indicator.

$\checkmark \quad$ For the OECD countries, GDP grew significantly faster than energy consumption between 1970 and 1992. This took place as a result of shifts away from the industrial sector and towards the service sector, reductions in energy intensity within sectors, and improvements in energy efficiency throughout the economy.

$\checkmark \quad$ For the non-OECD countries, energy consumption grew slightly faster than GDP between 1970 and 1992 partly as a result of electrification, industrial development, and growth in private vehicle ownership.

$\checkmark$ Electricity consumption grew significantly faster than overall energy consumption, GDP, and carbon emissions between 1970 and 1992, particularly in the non-OECD.

$\checkmark \quad$ In both non-OECD and OECD countries, carbon emissions grew slower than energy consumption and GDP, largely as a result of increased output of hydroelectric and nuclear power, both of which emit no carbon.

$\checkmark$ The decline in energy consumption and carbon emissions after 1990 in non-OECD countries is due to the economic collapse of the FSU and Eastern European countries. 


\section{Energy Consumption and Carbon Emissions: OECD vs. Non-OECD}
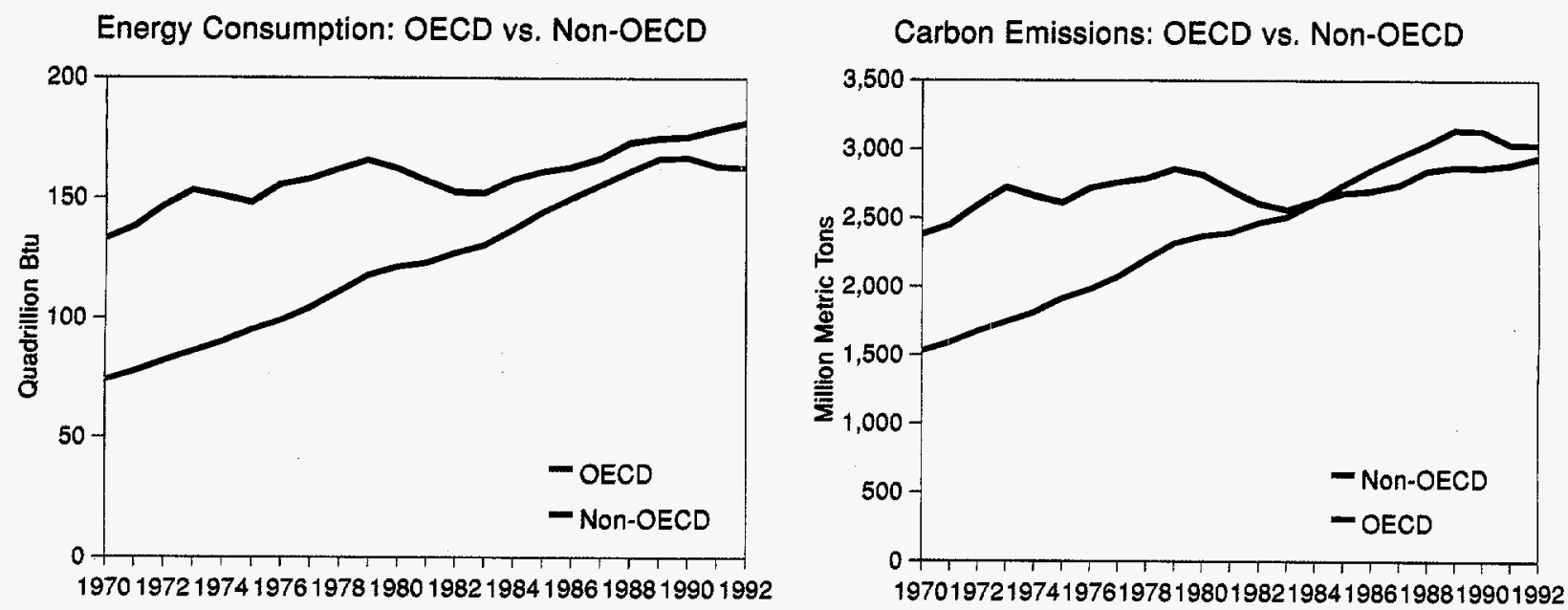

Source: See Appendix p. 53.

$\checkmark$ In absolute terms, total world energy demand grew 66 percent from 1970 to 1992, from 208 quadrillion Btu to 344 quadrillion Btu. Non-OECD energy demand grew 121 percent during the period, while OECD energy demand grew only 36 percent.

$\checkmark \quad$ During the same period, world carbon emissions increased 53 percent, from 3.9 billion tons in 1970 to nearly 6 billion tons in 1992. Most of this growth was accounted for by the non-OECD countries, where carbon emissions grew 99 percent during the period. In contrast, OECD carbon emissions grew 24 percent between 1970 and 1992.

$\checkmark$ The non-OECD share of world energy use and carbon emissions grew rapidly between 1970 and 1992, although this trend slowed beginning in the late 1980's due to the disintegration of the Soviet bloc, which resulted in sharp downturns in energy consumption and carbon emissions in that region.

$\checkmark$ Energy demand and carbon emissions grew steadily in the non-OECD despite the oil price shocks of the 1970's, pushed by rapid growth in population and economic output, along with market distortions in much of the region (which shielded it from oil price fluctuations).

$\checkmark$ World carbon emissions have grown along with world energy consumption, although at a slower rate. In the non-OECD, for example, energy consumption more than doubled between 1970 and 1992 , while carbon emissions doubled. In the OECD, energy consumption increased 36 percent between 1970 and 1992, while carbon emissions grew 24 percent.

$\checkmark$ The slower growth of carbon emissions relative to energy consumption worldwide between 1970 and 1992 can be explained by increased nuclear and hydroelectric power generation during the period, along with shifts in fossil fuel mix. 


\section{Non-OECD Regional Comparison}

The purpose of this section is to compare and contrast energy use and carbon emissions patterns across major non-OECD regions. These regions include: 1) the former Soviet Union (FSU) and Eastern Europe; 2) the non-OECD Pacific Rim countries; 3) Latin America; 4) Other Asia; and 5) Africa.

Key findings of this section include:

$\checkmark \quad$ The dominant forces pushing up non-OECD energy consumption and energy-related carbon emissions between 1970 and 1992 were growth in economic output and population. Carbon emissions rose in all non-OECD regions along with GDP and energy consumption.

$\checkmark \quad$ Energy intensity increased between 1970 and 1992 in all non-OECD regions except the Pacific Rim, where it declined sharply. The Pacific Rim stood out as the only non-OECD region exhibiting an energy intensity trend similar to the OECD (i.e., declining).

$\checkmark$ Energy consumption in the non-OECD Pacific Rim grew the most (in absolute terms) of any non-OECD region, from 16 quadrillion Btu in 1970 to 46 quadrillion Btu in 1992. Much of this growth was led by China, which experienced a 150 percent increase in energy consumption.

$\checkmark \quad$ Despite this growth, the FSU and Eastern Europe region maintained its position as the leading non-OECD energy consumer (and carbon emitter) between 1970 and 1992. The Pacific Rim was second for the most energy consumed and carbon emitted, while Africa consumed the least amount of energy and emitted the least amount of carbon.

$\checkmark$ Oil was the dominant fuel in Latin America, Africa, and Other Asia, and the second most used fuel in the other regions. Natural gas was the most heavily used fuel in the FSU and Eastern Europe, while coal dominated in the Pacific Rim because of China. Only in Latin America did nonfossil fuels (primarily hydroelectricity) account for more than 10 percent of energy consumption.

$\checkmark \quad$ Per capita GDP and energy consumption were highest in the FSU and Eastern Europe region and, although generally rising, remain far below OECD levels. Per capita GDP and energy consumption in other non-OECD regions were generally far below the FSU and Eastern Europe.

$\checkmark \quad$ Industry accounted for the largest share of non-OECD energy consumption and carbon emissions between 1980 and 1990. Industry's share fell only slightly between 1980 and 1990, in contrast to the group of seven countries, where it declined sharply.

$\checkmark \quad$ The residential/commercial sector's share of non-OECD energy use and carbon emissions increased only slightly between 1980 and 1990. Despite increased electrification and urbanization during the 1970's and 1980's, this sector still lagged far behind the industrial sector.

$\checkmark \quad$ Electricity demand grew more rapidly than overall energy demand in all non-OECD regions between 1971 and 1990. As a result, electricity's share of total regional energy consumption increased significantly throughout the non-OECD. 


\section{Population, Economic Growth, Energy \\ and Carbon}

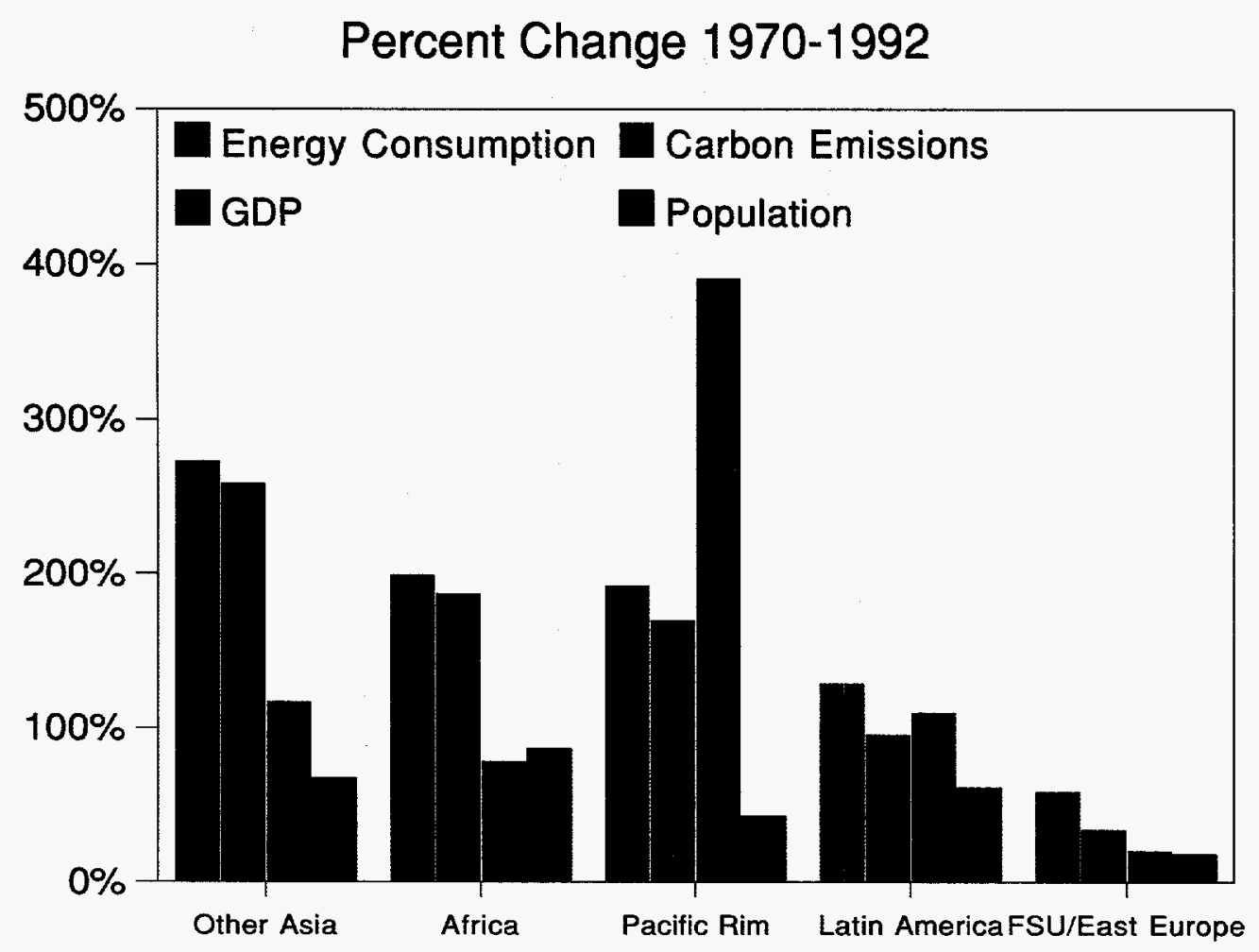

Source: See Appendix p. 53.

$\checkmark$ Energy consumption, carbon emissions, GDP, and population grew at widely varying rates among non-OECD regions between 1970 and 1992. The two largest regions (the FSU and Eastern Europe and the Pacific Rim), for example, displayed markedly different growth rates in these four variables.

$\checkmark \quad$ Energy consumption in the non-OECD grew fastest (on a percentage basis) between 1970 and 1992 in Other Asia, Africa, and the Pacific Rim. Energy consumption grew slowest in the FSU and Eastern Europe and Latin America.

$\checkmark$ Energy consumption increased faster than GDP in all non-OECD regions except for the Pacific Rim, where energy declined sharply relative to GDP. This decline in the Pacific Rim was due, overwhelmingly, to China.

GDP grew, by far, the fastest in the Pacific Rim between 1970 and 1992, and slowest in the FSU and Eastern Europe, Africa, and Other Asia regions.

$\checkmark$ Only in Africa did population grow faster than GDP between 1970 and 1992. 


\section{Energy Consumption by Region}

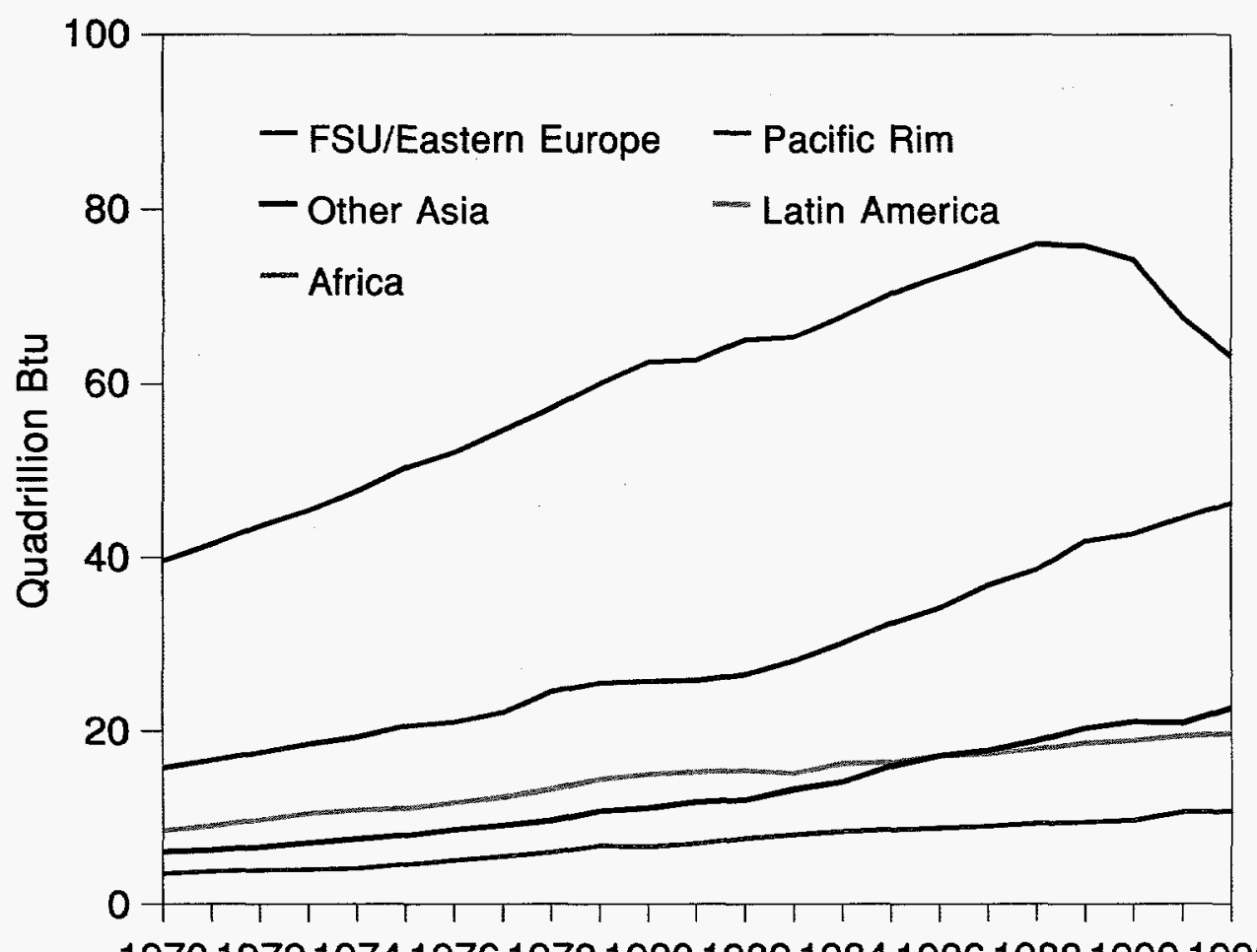

197019721974197619781980198219841986198819901992

Source: See Appendix p. 53.

$\checkmark \quad$ The countries of the FSU and Eastern Europe consumed the most energy among non-OECD regions between 1970 and 1992. FSU and Eastern European energy consumption fell sharply beginning in the late 1980 's, due to a severe economic downturn associated with the collapse of communism.

$\checkmark \quad$ Pacific Rim energy consumption, led by China, grew the most (in absolute terms) of any non-OECD region between 1970 and 1992, tripling from 15.8 quadrillion Btu to 46.3 quadrillion Btu. Much of this growth was led by China, which experienced a 150 percent increase in energy consumption, from 12 quadrillion Btu to about 30 quadrillion Btu.

$\checkmark \quad$ With the exception of Latin America, a single country in each region stands out as the largest energy consumer. In the Pacific Rim, China accounted in 1992 for 63 percent of regional energy consumption. In other regions: the FSU accounted for 81 percent of FSU and Eastern Europe energy consumption; India accounted for 38 percent of Other Asian consumption; and South Africa accounted for 41 percent of African energy consumption.

$\checkmark \quad$ Other Asian energy consumption nearly quadrupled between 1970 and 1992, from 6 to 23 quadrillion Btu. African energy consumption tripled from 3.6 to 10.8 quadrillion Btu. 


\section{Energy Consumption by Fuel Type and Energy-Related Carbon Emissions}
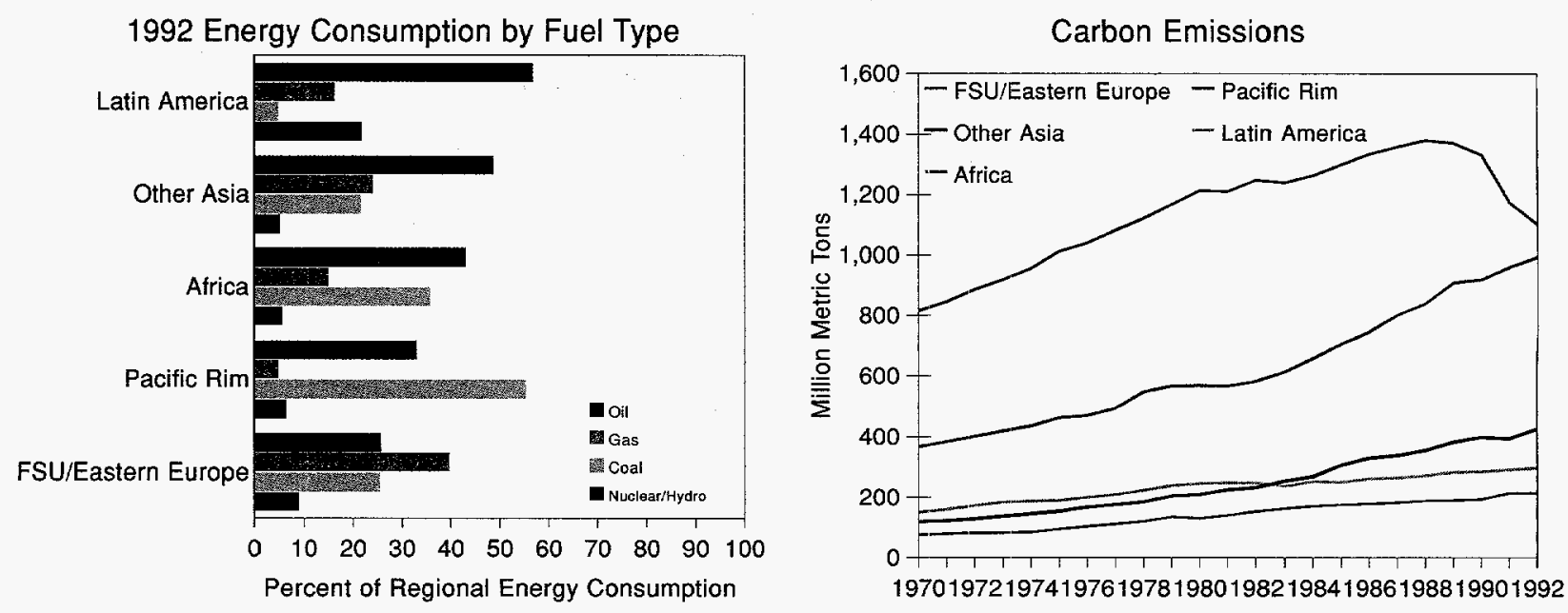

Source: See Appendix p. 53.

$\checkmark$ Oil was the predominant fuel in Latin America, Africa, and Other Asia, and the second most used fuel in the Pacific Rim and FSU and Eastern Europe regions.

$\checkmark$ The availability of plentiful supplies of natural gas in the FSU and Eastern Europe made it the most heavily used fuel in that region. Natural gas accounted for 15-25 percent of energy use in Other Asia, Latin America, and Africa, but less than 5 percent in the Pacific Rim.

$\checkmark$ Coal dominated in the Pacific Rim because of China's heavy use, and was the second-most used fuel in Africa (with a 35 percent share). In other regions, coal accounted for 20-30 percent of FSU and Eastern European and Other Asian energy consumption, but less than 5 percent of energy consumption in Latin America.

$\checkmark$ Only in Latin America, which used large amounts of hydroelectric power, did nuclear and renewables account for more than 10 percent of energy consumption.

$\checkmark$ Energy-related carbon emissions in the non-OECD countries were dominated by two regions---the FSU and Eastern Europe and the Pacific Rim---between 1970 and 1992. Each of these regions emitted more carbon than the other three non-OECD regions combined.

$\checkmark \quad$ Fuel mix is an important variable affecting carbon emissions. Increased use of nuclear power and natural gas in the FSU, for example, resulted in significantly lower growth in carbon emissions than energy consumption between 1970 and 1992. 


\section{GDP and Energy Consumption per Capita}
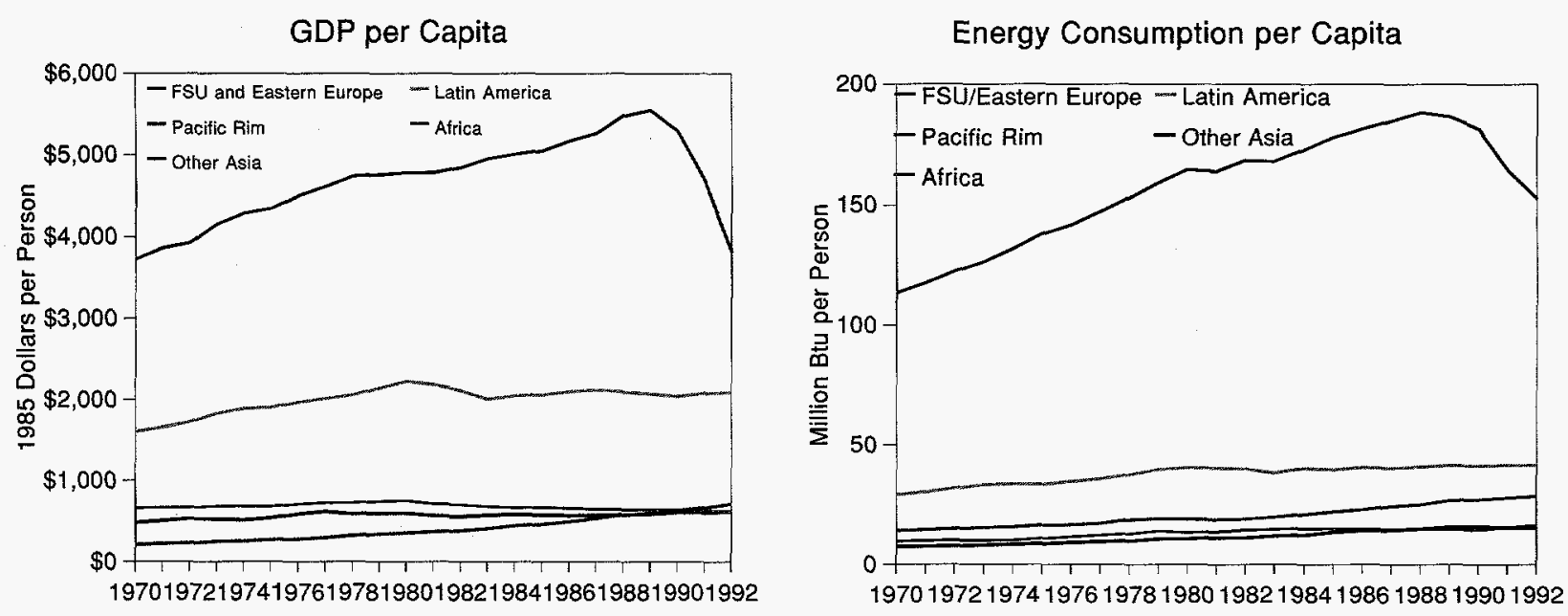

Source: See Appendix p. 54.

$\checkmark \quad$ Throughout the non-OECD, growth in per capita GDP was a driving force behind growth in per capita energy consumption between 1970 and 1992.

$\checkmark$ GDP per capita was highest in the FSU and Eastern Europe compared to any other non-OECD region. Even in the FSU and Eastern Europe, however, GDP per capita averaged less than half that of the OECD region. Latin America, which had the second highest non-OECD GDP per capita, averaged less than one quarter of the OECD.

$\checkmark$ Energy consumption per capita in the OECD is, on average, seven times greater than in the nonOECD. Only the FSU and Eastern Europe region consumes energy at per capita rates comparable to the OECD Europe and Japan (but still far less than the United States and Canada).

$\checkmark \quad$ Energy per capita consumption rates increased most rapidly (in percentage terms) between 1970 and 1992 in Other Asia, followed by the Pacific Rim. In absolute terms, the FSU and Eastern Europe grew the most, while Africa grew the least. 


\section{Energy Consumption per Dollar of GDP}

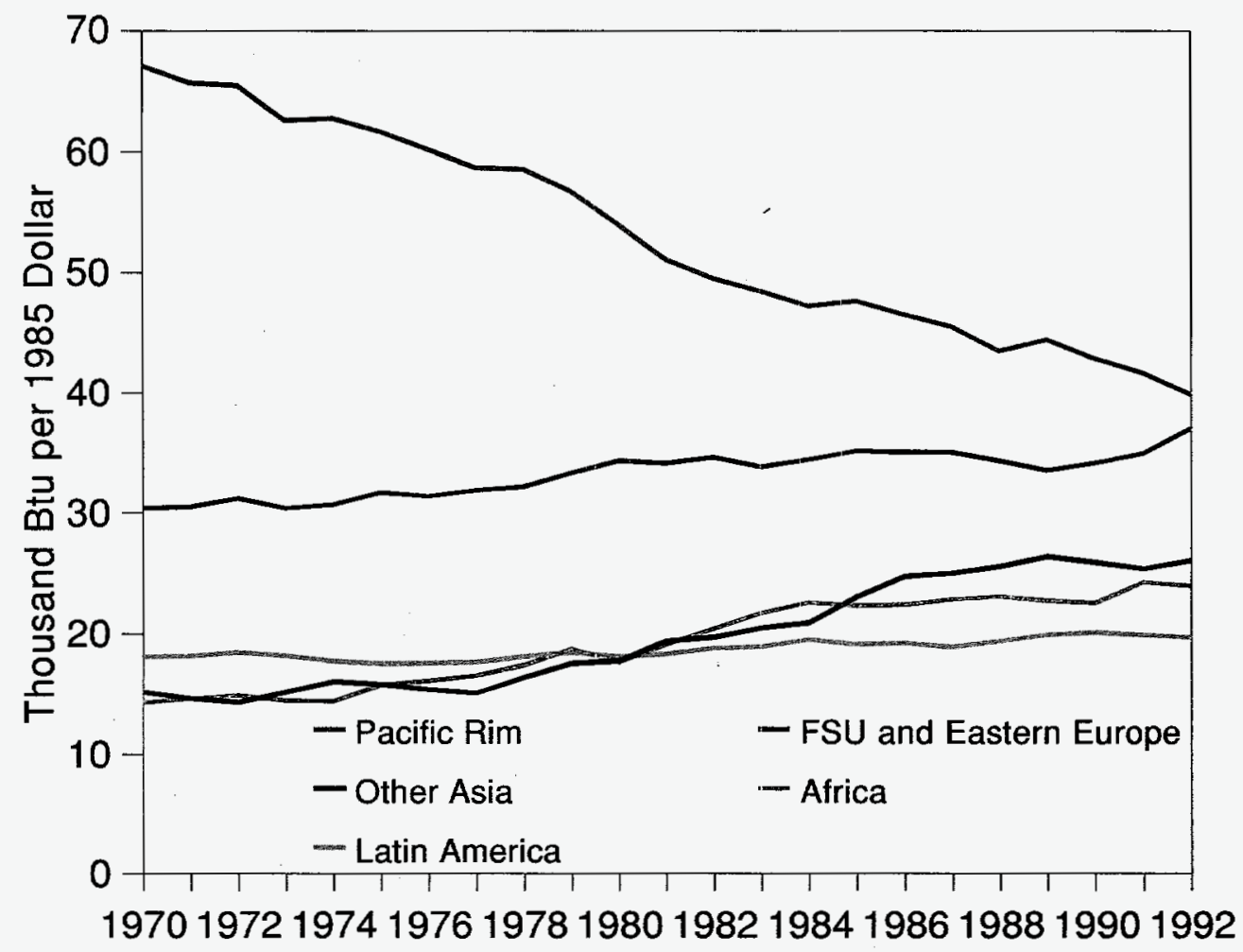

Source: See Appendix p. 54.

$\checkmark \quad$ Non-OECD energy intensity displayed two distinct trends between 1970 and 1992. In the Pacific Rim (as in the OECD), energy intensity declined sharply and steadily during the period. In all other non-OECD regions, energy intensity increased during the period.

$\checkmark$ As a result of these opposing trends, inter-regional differences tended to narrow over time with regards to energy intensity. Despite this convergence, Latin America still consumed less than half as much energy per dollar of output as the FSU and Eastern Europe and the Pacific Rim in 1992.

$\checkmark$ Energy consumption per GDP dollar rose sharply in the FSU and Eastern Europe after 1989 as a result of economic collapse in this region, as GDP fell more rapidly than energy consumption. 


\section{Energy Use and Carbon Emissions: \\ Non-OECD Rankings, 1992}

\begin{tabular}{|l|c|c|c|c|}
\hline \multicolumn{1}{|c|}{ Country } & $\begin{array}{c}\text { Carbon } \\
\text { Emissions } \\
\text { (million } \\
\text { metric tons) }\end{array}$ & $\begin{array}{c}\text { Cumulative } \\
\text { Non-OECD } \\
\text { Total } \\
\text { (percent) }\end{array}$ & $\begin{array}{c}\text { Energy Demand } \\
\text { (quadrillion } \\
\text { Btu) }\end{array}$ & $\begin{array}{c}\text { Cumulative } \\
\text { Non-OECD } \\
\text { Total } \\
\text { (percent) }\end{array}$ \\
\hline $\begin{array}{l}\text { Former Soviet } \\
\text { Union }\end{array}$ & 866.1 & 28.6 & 51.2 & 31.5 \\
\hline China & 673.1 & 50.8 & 29.2 & 49.4 \\
\hline India & 177.4 & 56.6 & 8.5 & 54.6 \\
\hline South Africa & 106.5 & 60.1 & 4.5 & 57.4 \\
\hline Poland & 92.1 & 63.2 & 4.0 & 59.8 \\
\hline Mexico & 91.9 & 66.2 & 5.1 & 63.0 \\
\hline South Korea & 91.3 & 69.2 & 4.9 & 66.0 \\
\hline Brazil & 70.5 & 71.5 & 6.1 & 69.7 \\
\hline Saudi Arabia & 63.5 & 73.6 & 3.5 & 71.9 \\
\hline Iran & 61.6 & 75.7 & 3.4 & 74.0 \\
\hline \hline
\end{tabular}

$\checkmark$ Several non-OECD countries (including the FSU, which collapsed at the end of 1991) made up a disproportionate share of non-OECD energy use and carbon emissions in 1992. The ten countries with the largest carbon emissions accounted for about three quarters of non-OECD energy consumption and carbon emissions.

$\checkmark$ Combined, these 10 countries emitted 2,294 million metric tons of carbon in 1992 and consumed 120 quadrillion Btu of energy. This represented 38 percent of world carbon emissions and 35 percent of world energy consumption.

$\checkmark \quad$ Of these countries, the FSU and China made up by far the largest single shares, together accounting for about half of non-OECD energy demand and carbon emissions in 1992.

$\checkmark \quad$ If the FSU were replaced in this table by its successor republics, the table would show that three of them would rank among the ten largest non-OECD carbon emitters: Russia (number 2 with 542.6 million metric tons of carbon), Ukraine (number 4 with 152.4 million metric tons of carbon), and Kazakhstan (number 10 with 63.7 million metric tons of carbon). 


\section{Regional Energy Consumption by Sector and Fossil Fuel and Total Energy Consumption}

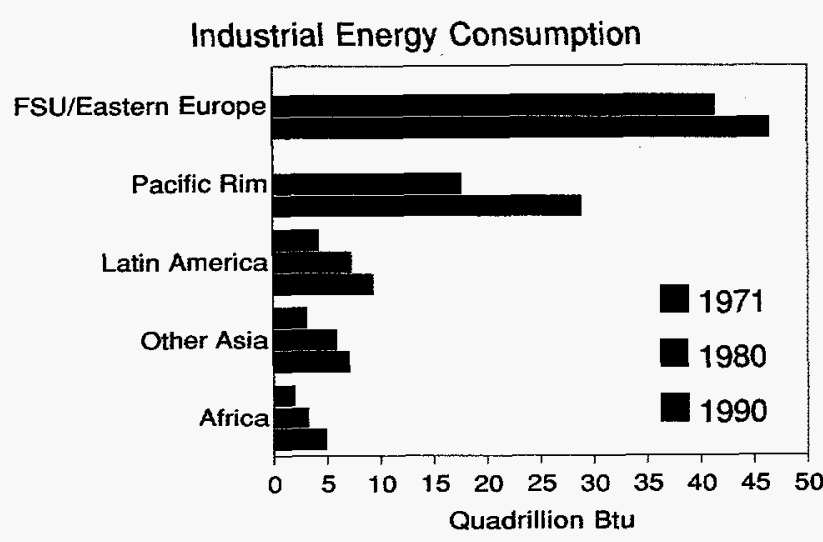

Note: Data available for over $90 \%$ of consumption in 1990 in all regions except Africa $(75 \%)$.

1971 data is unavalable for many countries; a few counities have no sectoral breakdown.

The latest data is used for Algeria(1988), Iran(1989), Iraq(1988), Poland(1988), Saudi Arabia(1986).

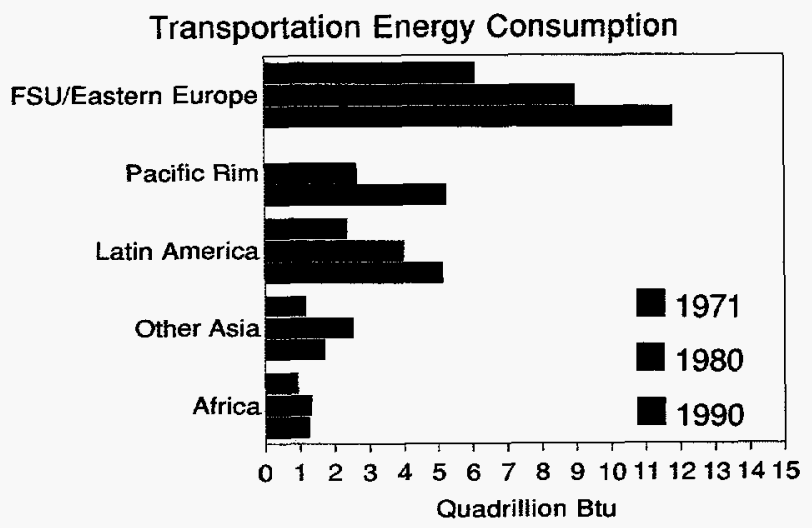

Note: Data available for over $90 \%$ of consumption in 1990 in all regions except Africa (75\%).

1971 data is unavailable for many countries; a tew countries have no sectoral breakdown.

The latest data is used for Algeria(1988), lran(1989), Iraq(1988), Poland(1988), Saudi Arabia(1986).

\section{Residential/Commercial Energy Consumption}

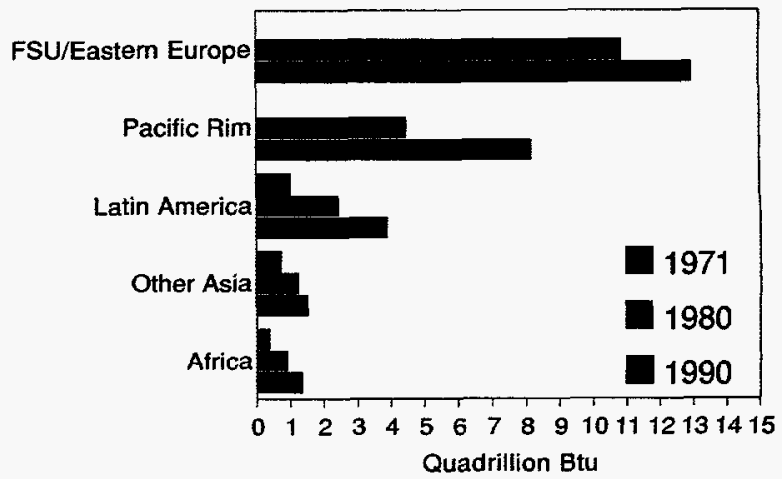

Note: Data available for over $90 \%$ of consumption in 1990 in all segions except Atrica (75\%). 1971 data is unavailable for many countries; a few countries have no sectoral breakdown. The latest data is used for Algeria(1988), Iran(1989), Iraq(1988), Poland(1988), Saudi Arabia(1986).

\section{Fossil Fuel and Total Energy Consumption}

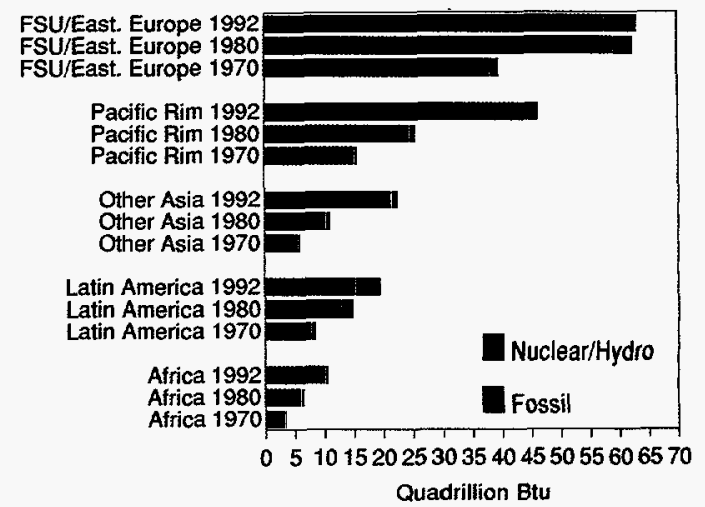

Note: The graphs cannot be directly compared because of differences in scale.

Source: See Appendix p. 54.

$\checkmark \quad$ Energy consumption in all non-OECD regions was dominated by industry between 1971 and 1990 . This dominance was most pronounced in the relatively industrialized FSU/Eastern and Pacific Rim regions.

$\checkmark \quad$ Industrial energy consumption increased the most between 1971 and 1990, although transportation and residential/commercial also increased rapidly in most regions.

$\checkmark$ Energy consumption in all non-OECD regions was dominated by fossil fuels, with nuclear and hydroelectric power lagging far behind. 


\section{Electricity Overview}
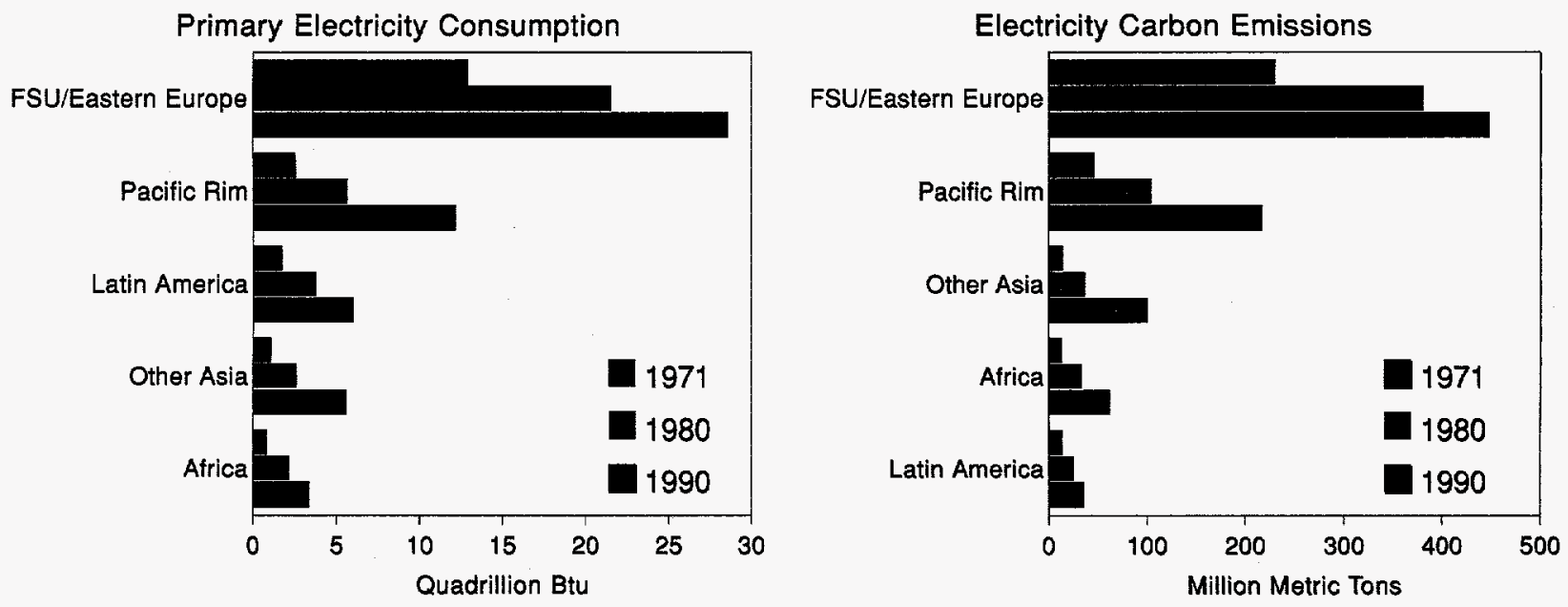

Note: The graphs cannot be directly compared because of differences in scale.

Source: See Appendix p. 54.

$\checkmark$ Electricity demand grew more rapidly than overall energy demand in all non-OECD regions between 1971 and 1990. As a result, electricity's share of total regional energy consumption increased significantly throughout the non-OECD.

$\checkmark$ In 1990, electricity consumption accounted for 33 percent of non-OECD energy demand, compared to 38 percent in the G-7.

$\checkmark \quad$ Electricity growth rates were highest in Latin America and the Pacific Rim between 1971 and 1990. Electric power growth was slowest in the FSU and Eastern Europe during this period.

$\checkmark \quad$ Carbon emissions from electricity generation also grew rapidly between 1971 and 1990, especially in the Pacific Rim, Other Asia, and Africa, all of which rely heavily on coal and oil. Growth was slowest in Latin America and the FSU and Eastern Europe regions, where hydroelectric, nuclear, and natural gas make up a larger share of the regional fuel mix. 


\section{The Former Soviet Union and Eastern Europe}

The purpose of this section is to provide information on differences in energy consumption patterns and carbon emissions within the former Soviet Union and Eastern Europe.

Key findings of this section include:

$\checkmark \quad$ The FSU dominated the region's energy consumption and carbon emissions between 1970 and 1992. The FSU alone made up 81 percent of the FSU and Eastern Europe region's energy consumption in 1992, and 79 percent of its carbon emissions.

$\checkmark \quad$ The FSU and Eastern Europe as a region consume energy and emit carbon at about twice the rate per dollar of GDP compared to the OECD countries of Western Europe. The high energy and carbon intensities displayed by the FSU and Eastern Europe resulted from: 1) heavy reliance on energy-intensive industries (e.g., steel in Poland; energy extraction industries in Romania and the FSU); 2) economic distortions caused by central planning and non-market pricing; and 3) relatively low penetration of energy-saving technology.

$\checkmark$ The shares of natural gas and nuclear/renewables (mainly nuclear) in the FSU and Eastern Europe's energy mix approximately doubled between 1970 and 1992, replacing coal. Oil's share also fell, although not as sharply as coal's, from 34 percent in 1970 to 26 percent in 1992.

$\checkmark$ Industrial consumption in the FSU was the largest in the world. The FSU's industrial sector consumed 37 quadrillion Btu of energy in 1990, surpassing the U.S. industrial sector's energy consumption by 7 quadrillion Btu.

$\checkmark \quad$ The FSU and Eastern Europe region consumed as much electricity as all other non-OECD regions combined. Electricity consumption in this region in 1990 totalled 29 quadrillion Btu, slightly less than the United States total.

$\checkmark \quad$ Electricity accounted for nearly 40 percent of the FSU and Eastern Europe's energy consumption in 1990. The FSU and Eastern Europe region was the most heavily electrified nonOECD region (as a share of total energy consumption) in 1990.

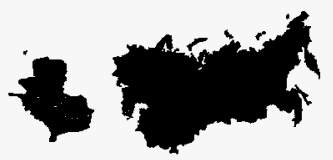




\section{Energy Consumption by Fuel Type and Energy-Related Carbon Emissions}

Fuel Use

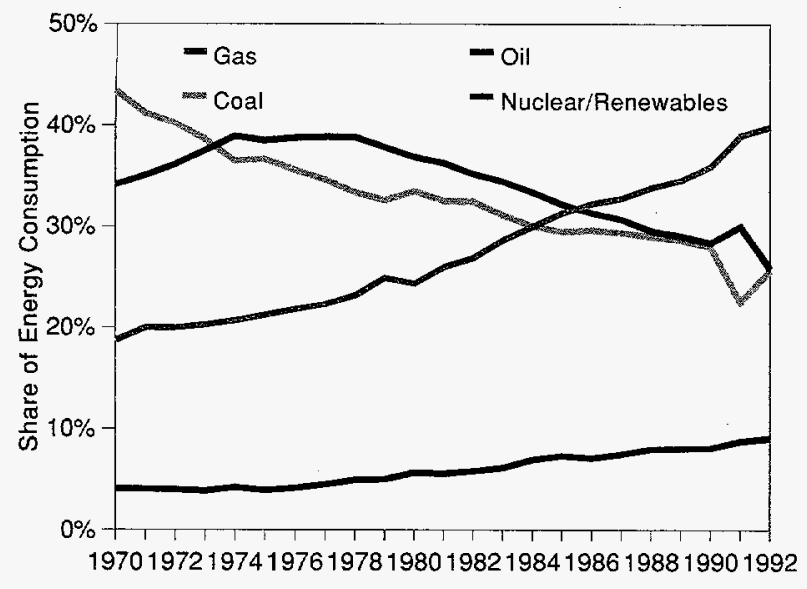

Carbon Emissions

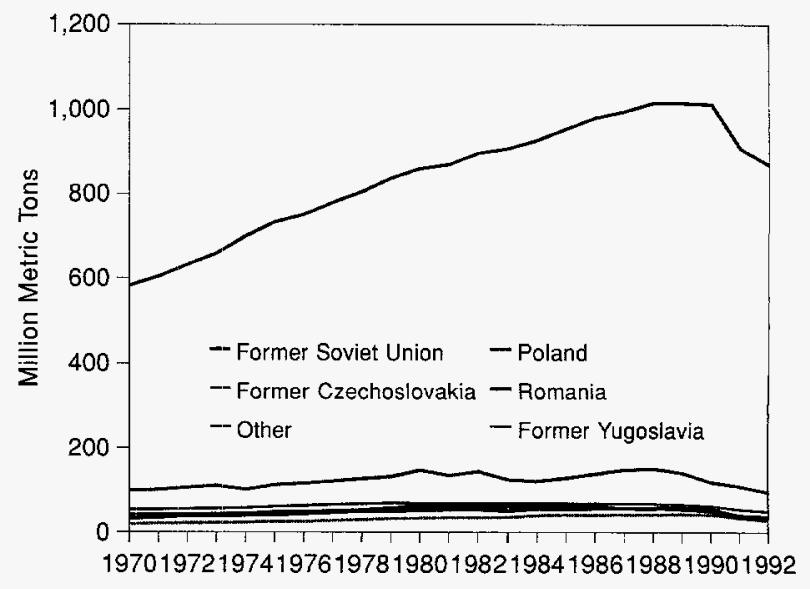

Source: See Appendix p. 54.

$\checkmark$ As of 1992, the FSU and Eastern Europe region consumed 63 quadrillion Btu of energy, of which natural gas accounted for 23 quadrillion Btu, oil for 16 quadrillion Btu, and coal for 16 quadrillion Btu. Nuclear and "renewables" accounted for 9 percent of the region's energy consumption.

$\checkmark$ The share of natural gas in the FSU and Eastern Europe's energy mix approximately doubled between 1970 and 1992 to about 40 percent, the highest such share in the non-OECD.

$\checkmark \quad$ Nuclear and renewables (mainly hydroelectric power) also approximately doubled between 1970 and 1992, mainly as a result of growth in FSU nuclear output.

$\checkmark \quad$ The FSU accounted for the largest share of regional carbon emissions between 1970 and 1992.

$\checkmark$ FSU carbon emissions rose from about 600 million metric tons in 1970 to about 1 billion metric tons (one sixth of the world total) in 1990. Since 1990, FSU energy use and carbon emissions have declined as a result of a severe economic downturn, but not as rapidly as gross domestic product has declined.

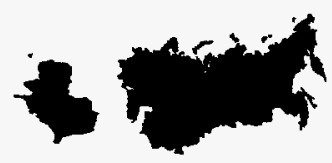




\section{GDP and Energy Consumption per Capita}
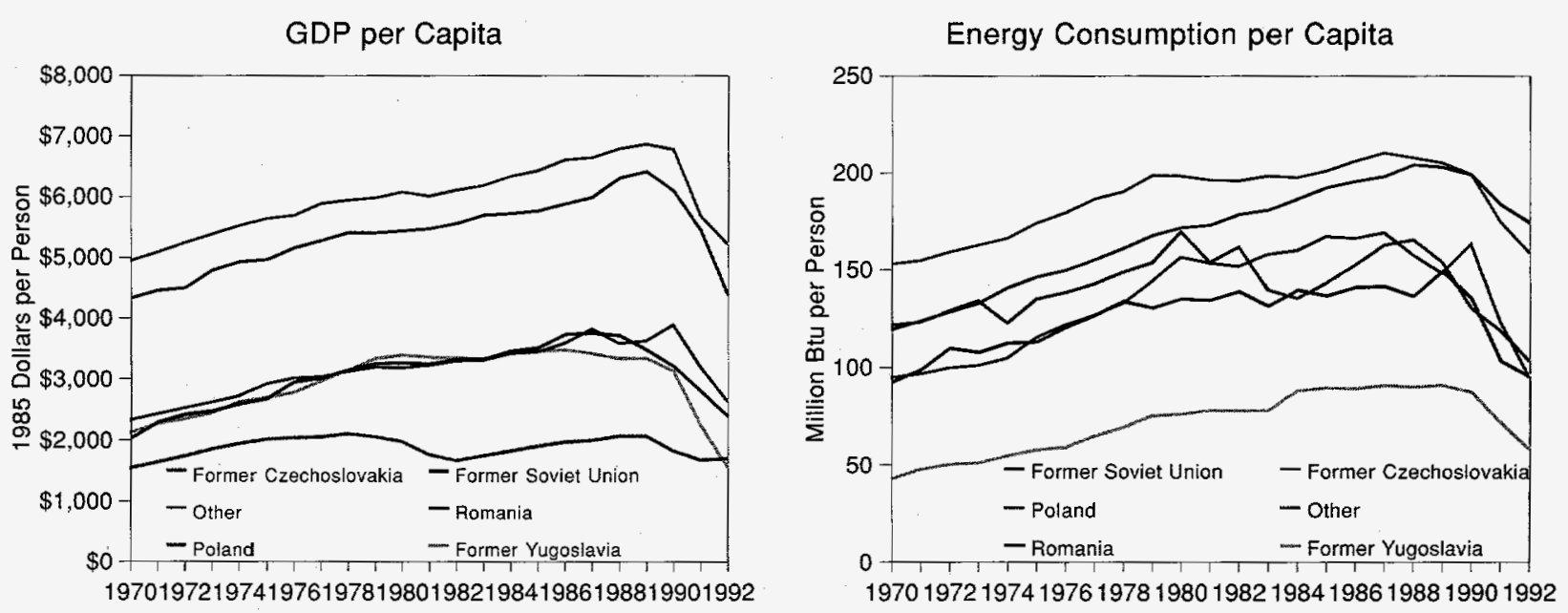

Source: See Appendix p. 54.

$\checkmark$ Per capita GDP varied widely in the FSU and Eastern Europe region, with the FSU and former Czechoslovakia generating three times as much GDP per person as Poland.

$\checkmark$ Per capita energy consumption in the FSU and Eastern Europe grew steadily along with per capita GDP between 1970 and the late 1980's. Economic turmoil after that period of time led to a sharp downturn in energy use per capita during the early 1990's.

$\checkmark$ Despite this recent downturn, per capita energy consumption ratios remain relatively high in the FSU and Eastern Europe region, comparable to those of Japan and OECD Europe.

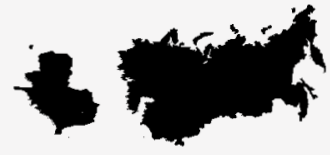




\section{Energy Consumption per Dollar of GDP}

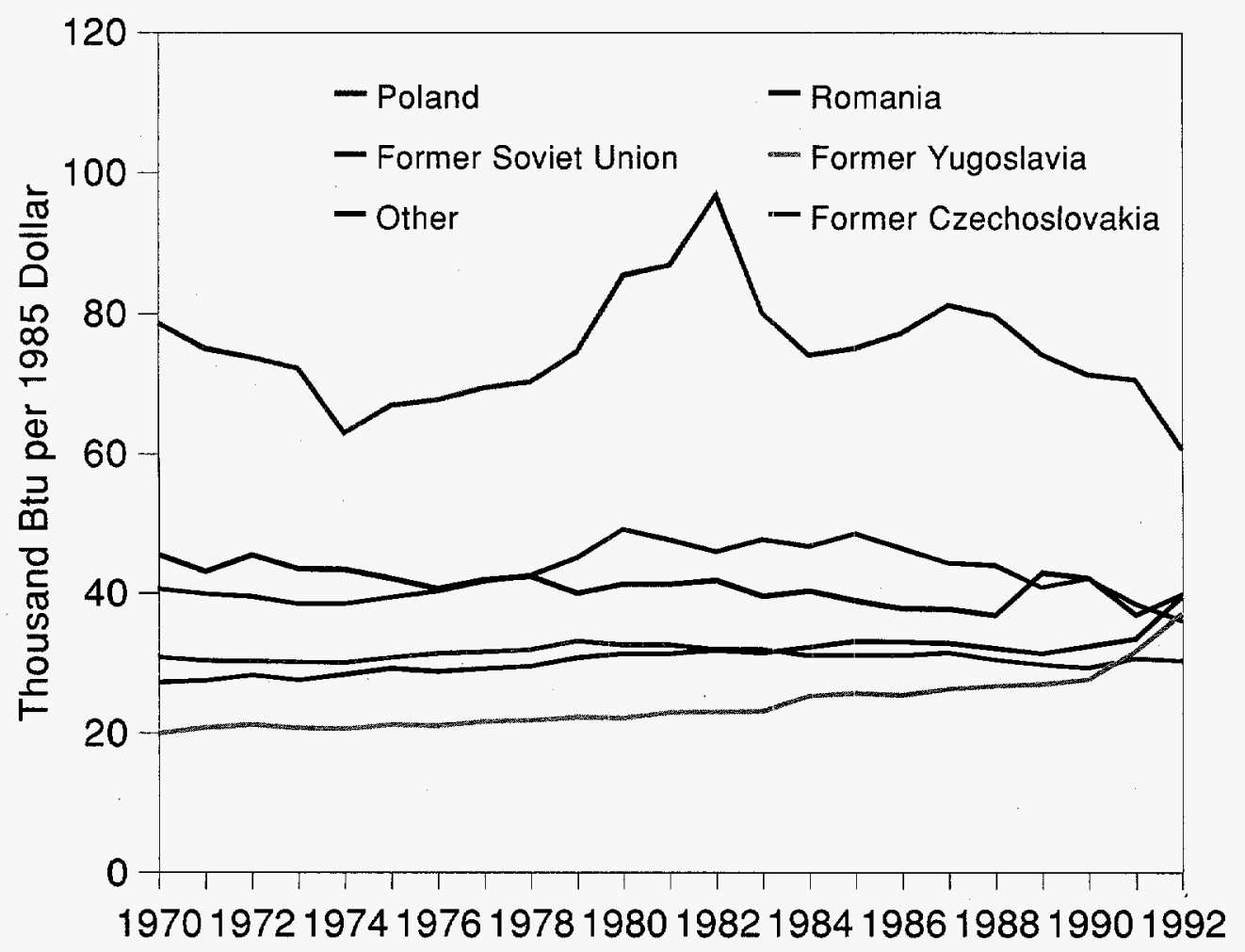

Source: See Appendix p. 55.

$\checkmark$ Energy consumption per dollar of GDP rose slightly in the FSU and Eastern Europe region between 1970 and 1992. Overall, the FSU and Eastern Europe consumed energy at nearly twice the rate per dollar of GDP as did the OECD countries of Western Europe during the period.

$\checkmark$ Poland maintained the highest energy consumption per constant dollar of GDP between 1970 and 1992.

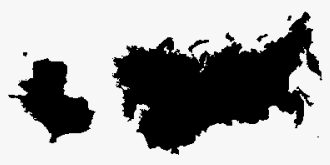




\section{Energy Consumption by Sector and Fossil Fuel and Total Energy Consumption}

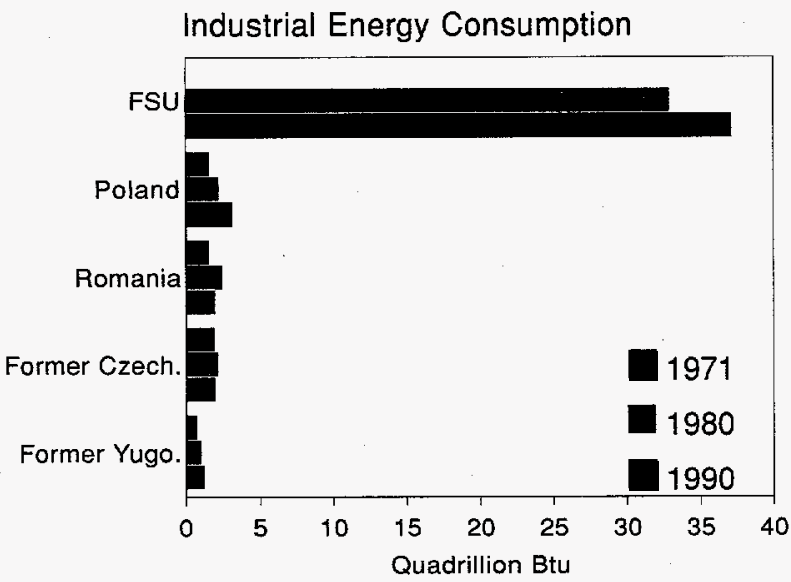

Note: 1971 sectoral data unavailable for Former Soviet Union; latest data (1988) used for Poland.

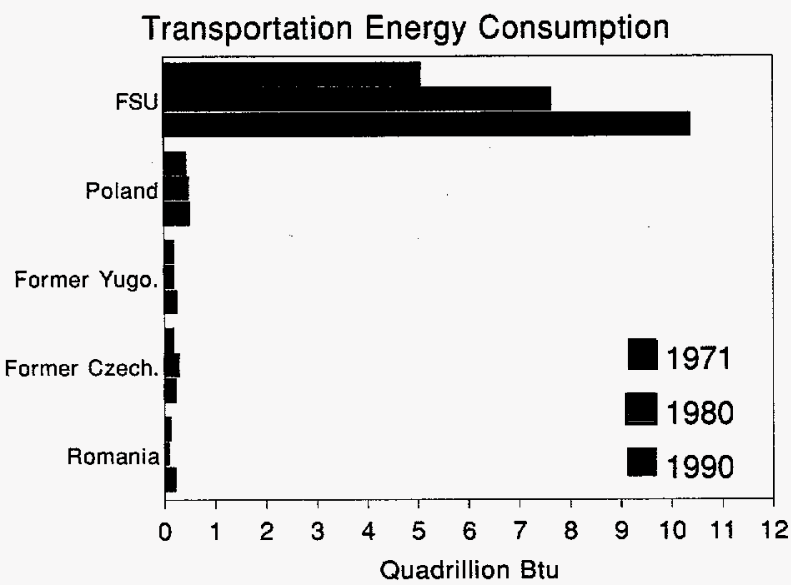

Note: Latest data (1988) used for Poland.
Residential/Commercial Energy Consumption

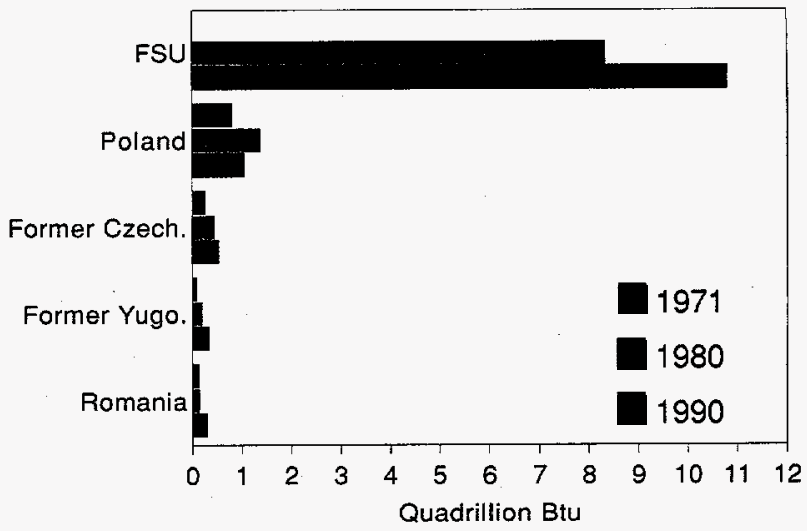

Note: 1971 sectoral data unavailable for Former Soviet Union; latest data (1988) used for Poland.

Fossil Fuel and Total Energy Consumption

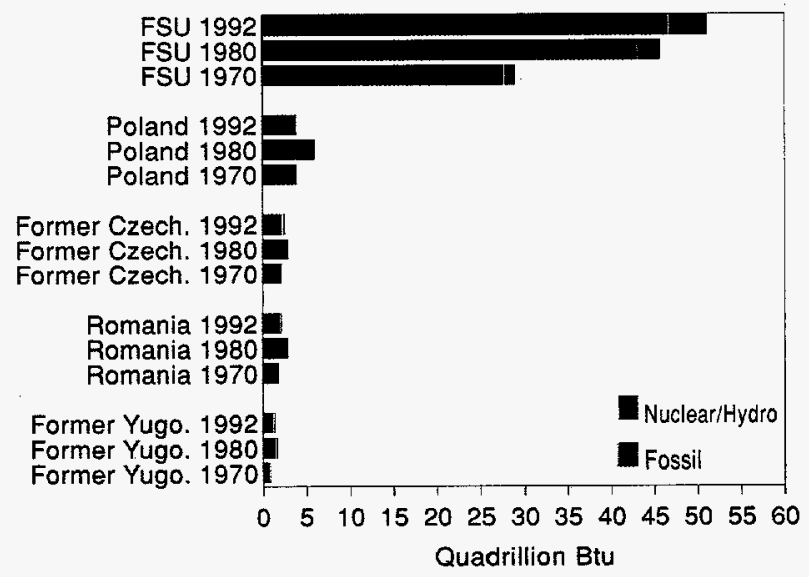

Note: The graphs cannot be directly compared because of differences in scale.

Source: See Appendix p. 55.

Energy consumption in the FSU and Eastern Europe region was dominated by the industrial sector between 1971 and 1990.

$\checkmark$ Industrial consumption in the FSU was the largest in the world, with its 37 quadrillion Btu in 1990 surpassing the U.S. industrial sector by 7 quadrillion Btu.

$\checkmark \quad$ Although nuclear and hydroelectric power consumption grew rapidly in the FSU and Eastern Europe region between 1970 and 1992, fossil fuels continued to dominate overall energy consumption throughout the region.

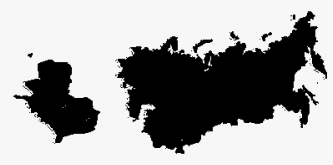




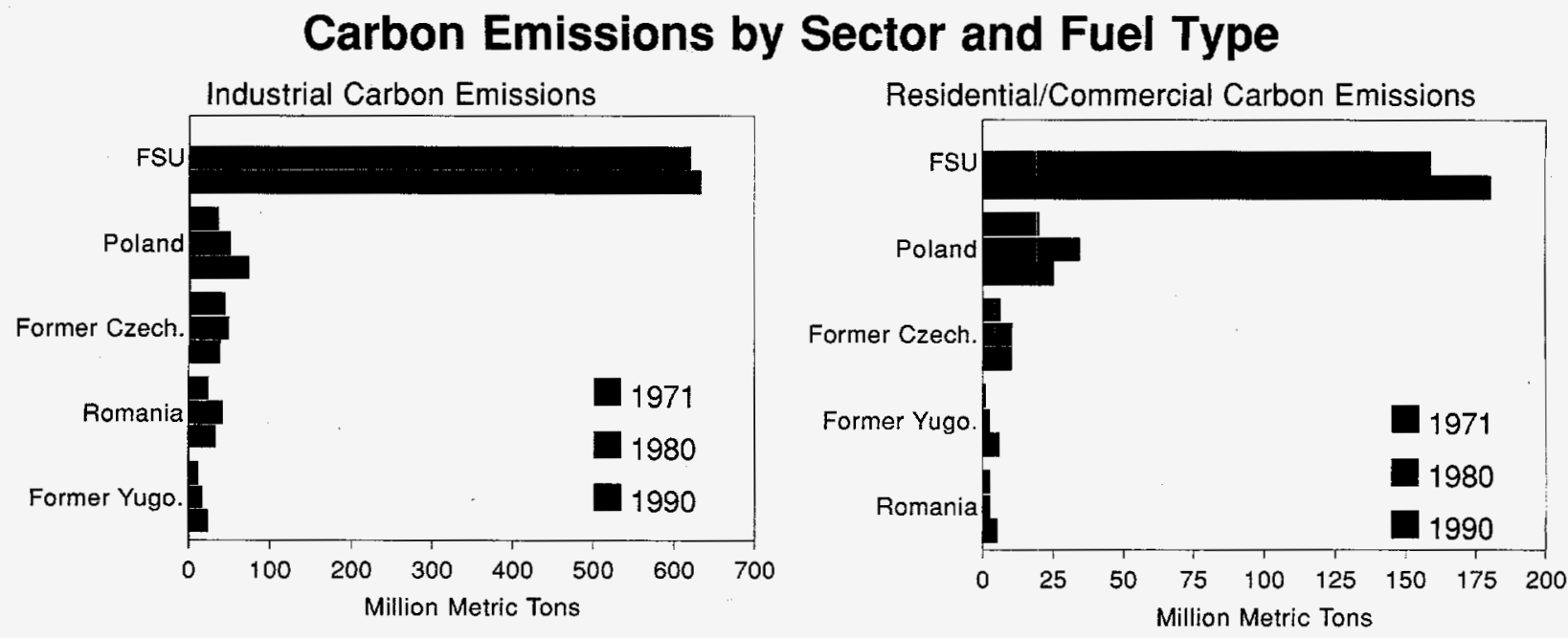

Note: 1971 sectoral data unavailable for Former Soviet Union; latest (1988) data used for Poland. Note: 1971 sectoral data unavailable for Former Soviet Union; latest data (1988) used for Poland.
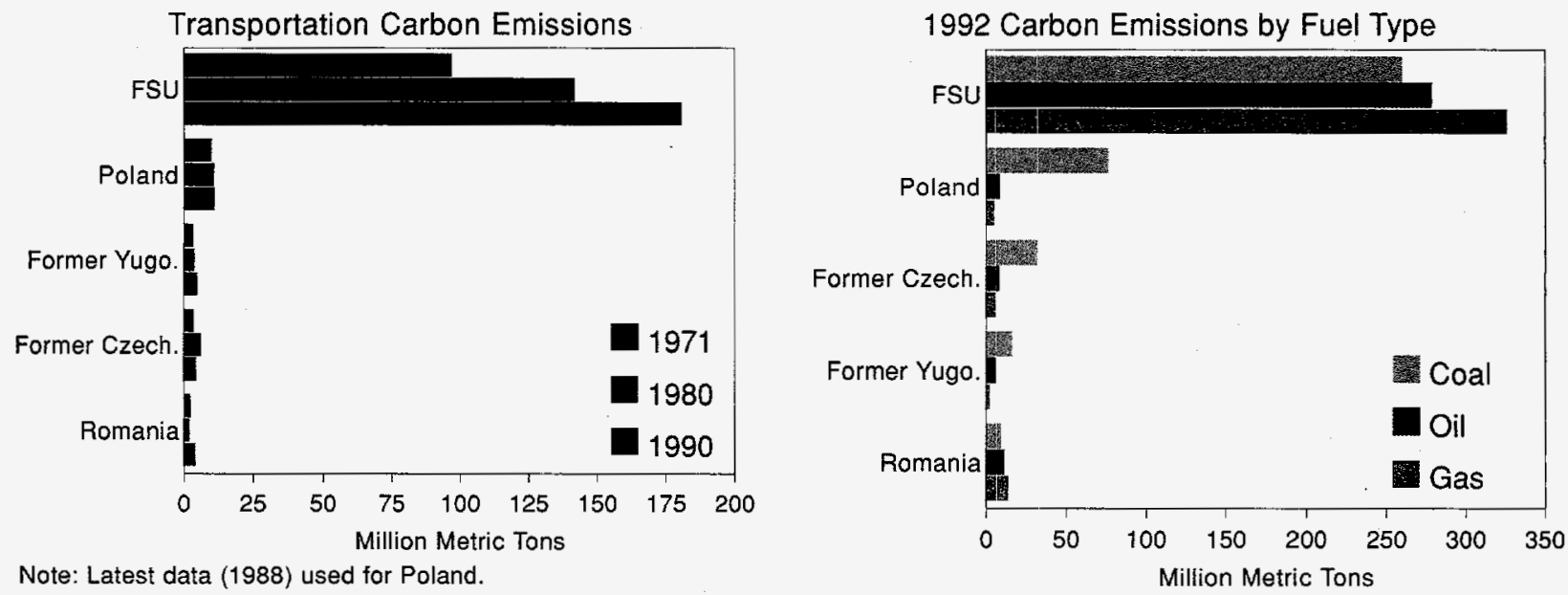

Note: Latest data (1988) used for Poland.

Note: The graphs cannot be directly compared because of differences in scale.

Source: See Appendix p. 55.

$\checkmark$ Carbon emissions in the FSU and Eastern Europe region were dominated by industry.

$\checkmark$ Carbon emissions grew most rapidly (in percentage terms) in the transportation sector.

$\checkmark$ The FSU and Eastern Europe's industrial sector was responsible for nearly one seventh of world carbon emissions in 1990, almost double the amount emitted by the G-7 industrial sector.

$\checkmark$ The residential/commercial and transportation sectors in the FSU and Eastern Europe region combined emitted 530 million metric tons (2/3 of industrial emissions) of carbon in 1990.

$\checkmark \quad$ In the FSU and Romania, natural gas accounted for the largest share of national carbon emissions. In contrast, coal dominated carbon emissions in the rest of the region.

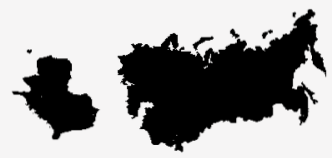




\section{Electricity Overview}
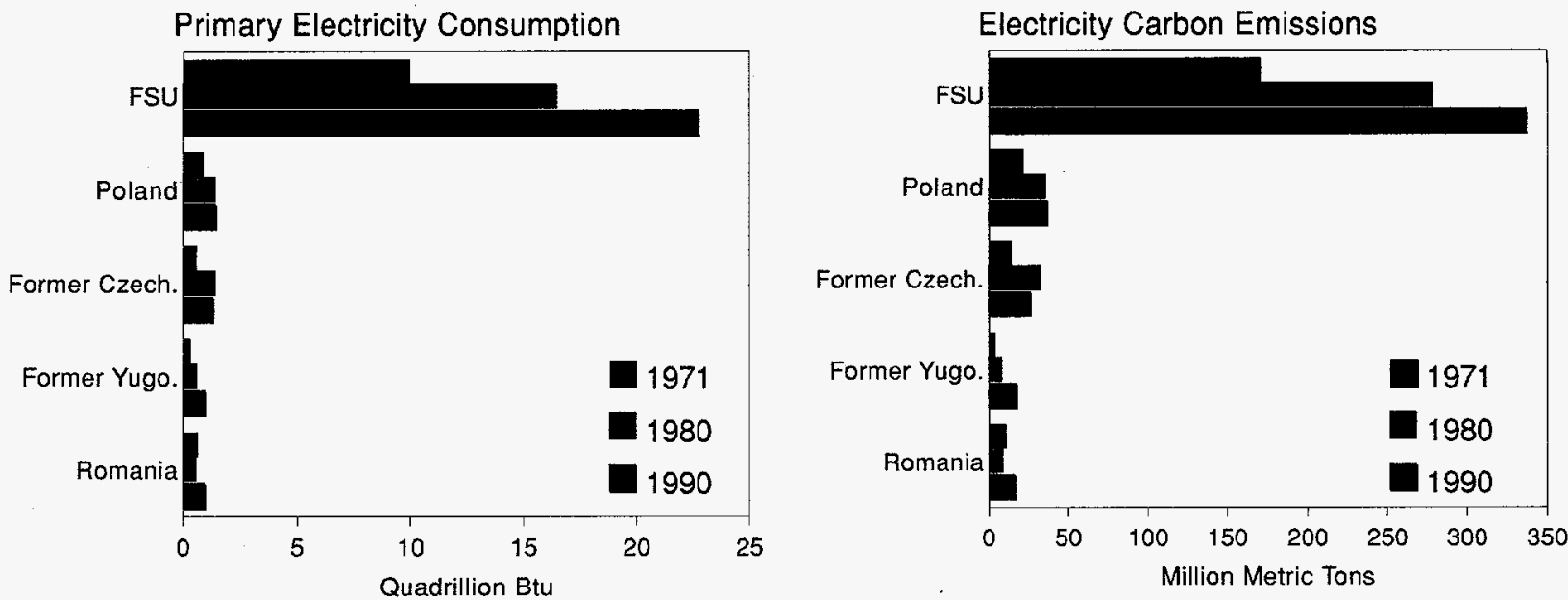

Source: See Appendix p. 55.

$\checkmark$ Electricity consumption in the region increased by 7 quadrillion Btu between 1980-1990, the largest absolute increase of any non-OECD region. In relative terms, however, FSU and Eastern European electricity consumption grew more slowly than in other non-OECD regions.

$\checkmark$ More than 40 percent of carbon emissions in former Yugoslavia and former Czechoslovakia resulted from electricity generation. FSU electricity generation accounted for about 33 percent of total FSU carbon emissions.

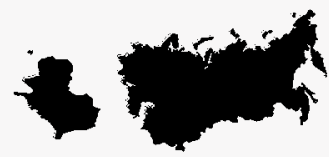




\section{Pacific Rim}

The purpose of this section is to provide information on differences in energy consumption and carbon emissions within the non-OECD Pacific Rim.

Key findings of this section include:

$\checkmark \quad$ The Pacific Rim region consumed more energy and emitted more carbon in 1992 than any other non-OECD region besides the FSU and Eastern Europe. In 1992, the Pacific Rim consumed 46 quadrillion Btu of energy and emitted 993 million metric tons of carbon.

$\checkmark \quad$ No other area of the world relied as heavily on coal for its energy needs. Led by China, coal accounted for about 60 percent of the Pacific Rim's energy consumption between 1970 and 1992 .

$\checkmark$ GDP per capita and energy consumption per capita rose sharply throughout the Pacific Rim region between 1970 and 1992 . Growth was especially strong in the rapidly industrializing countries of Taiwan and South Korea.

Led by China, energy intensity fell sharply in the Pacific Rim between 1970 and 1992 and led to corresponding sharp declines in carbon emissions per dollar of GDP. The dramatic decline in China's energy and carbon intensities between 1970 and 1992, larger than in the G-7 countries, resulted from a number of factors, including: 1) a shift away from central planning and towards more market-oriented economic policies under leader Deng Xiao-Ping beginning in the early 1980's; 2) government programs to reduce energy consumption in state-owned industries; and 3) structural shifts in China's economy.

$\checkmark$ Electricity consumption in the Pacific Rim doubled between 1971-1980 and again between 19801990. Pacific Rim electricity consumption increased from to 3 quadrillion Btu in 1971 to 12 quadrillion Btu in 1990, a growth rate more than twice that of the G-7 countries.

$\checkmark$ Energy consumption in the Pacific Rim is dominated by one sector in one country---the industrial sector in China. This sector alone consumed 21 quadrillion Btu in 1990, nearly half of total Pacific Rim energy consumption of 43 quadrillion Btu.

$\checkmark$ Coal accounted for the highest share of Pacific Rim energy consumption between 1970 and 1992. China, in particular, relied heavily on coal. Oil's share tended to fluctuate along with oil prices. Natural gas and nuclear/renewables increased their shares of Pacific Rim energy consumption between 1970 and 1992, but still accounted for only 10-15 percent of the total fuel mix.

$\checkmark \quad$ Carbon emissions from the Pacific Rim were dominated by China between 1970 and 1992. Chinese energy consumption increased dramatically despite large reductions in energy intensity. Pacific Rim energy-related carbon emissions grew rapidly between 1970 and 1992, with rapidly industrializing economies like China, South Korea, Indonesia, and Taiwan leading the way.

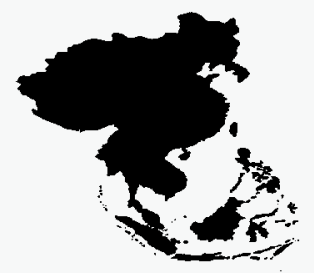




\section{Energy Consumption by Fuel Type and Energy-Related Carbon Emissions}
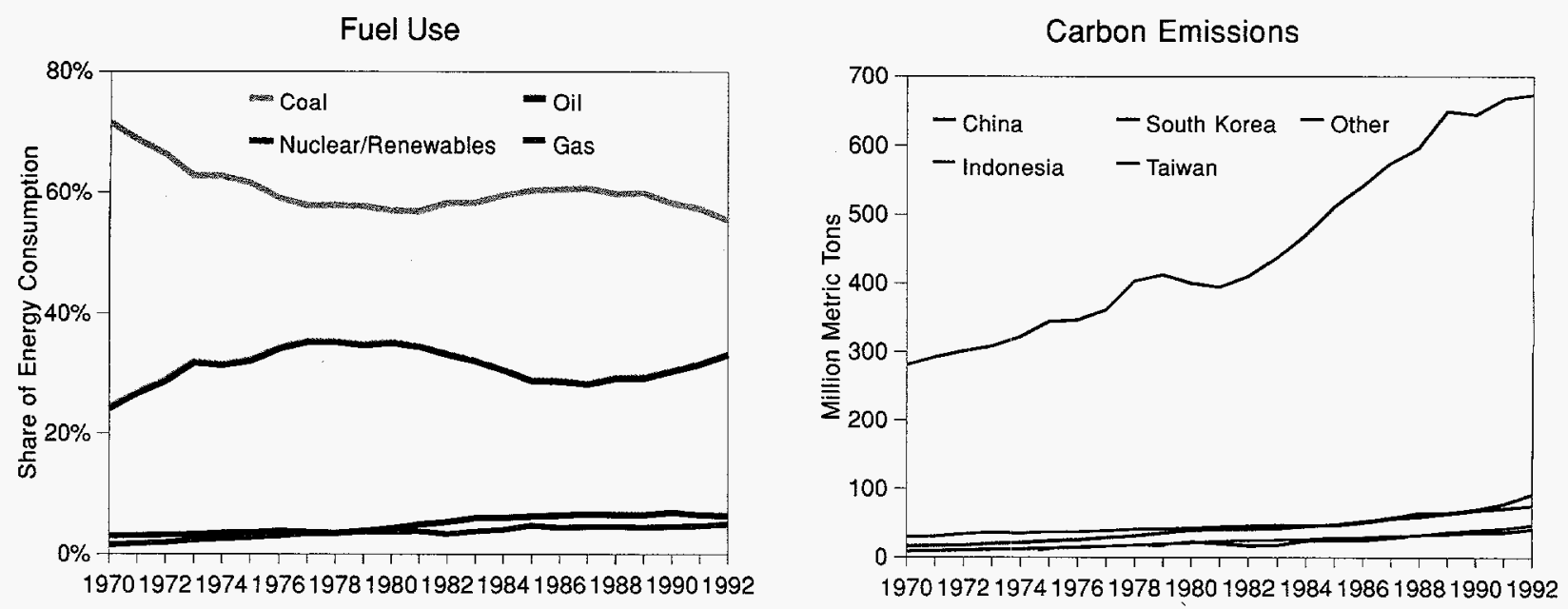

Source: See Appendix p. 55.

$\checkmark \quad$ Coal accounted for the highest share of Pacific Rim energy consumption between 1970 and 1992. China, in particular, relied heavily on coal. Coal's share remained constant at approximately 60 percent between the mid-1970's and 1992.

$\checkmark$ Oil's share increased significantly during the 1970's. Oil fell during the early 1980's following the 1979 oil price shock, and began rising again after the oil price collapse of 1985 and 1986.

$\checkmark$ Natural gas and nuclear/renewables increased their shares of Pacific Rim energy consumption between 1970 and 1992, but still accounted for only about 10-15 percent of the total fuel mix.

$\checkmark$ Carbon emissions from the Pacific Rim are dominated by China. Between 1970 and 1992, Chinese carbon emissions increased from 281 to 673 million metric tons, while total emissions for the region grew from 337 to 993 million metric tons.

$\checkmark$ Outside of China, Pacific Rim energy-related carbon emissions grew more than six-fold between 1970 and 1992. Indonesia's emissions increased nearly eight-fold during the period, Thailand's seven-fold, South Korea's six fold, and Taiwan's more than five-fold during the period. Most of the growth in carbon emissions from these countries was associated with increased use of oil.

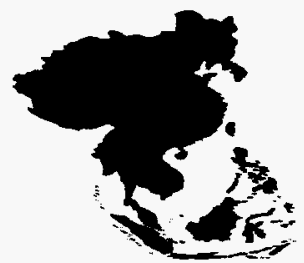




\section{GDP and Energy Consumption per Capita}
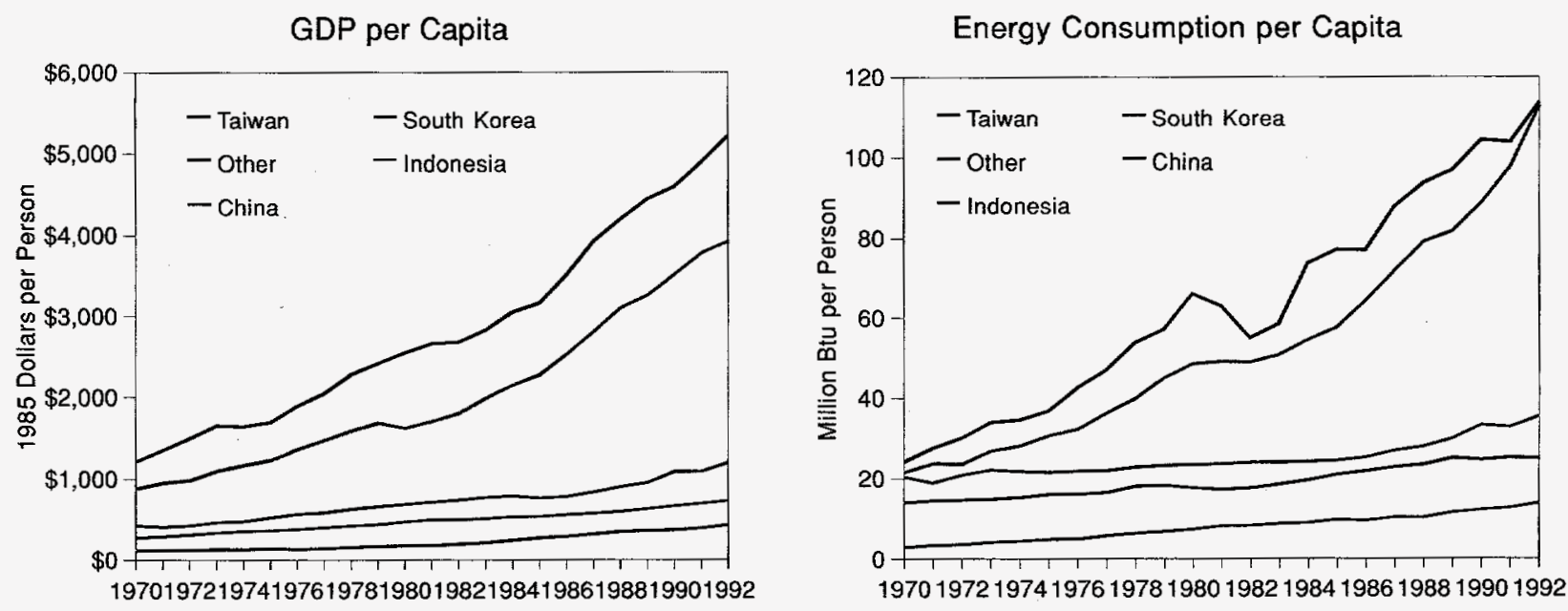

Source: See Appendix p. 55

$\checkmark$ GDP per capita rose sharply in several countries of the Pacific Rim region between 1970 and 1992. Growth was strongest in the rapidly industrializing countries of southeast Asia, such as Taiwan and South Korea.

$\checkmark$ China's energy consumption increased 151 percent between 1970 and 1992, while its population grew 41 percent. As a result of these two trends, China's energy consumption per capita grew 78 percent between 1970 and 1992.

$\checkmark \quad$ Energy consumption per capita more than tripled in Taiwan and South Korea between 1970 and 1992, nearing levels observed in the FSU and OECD Europe.

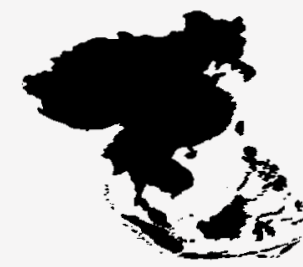




\section{Energy Consumption per Dollar of GDP}

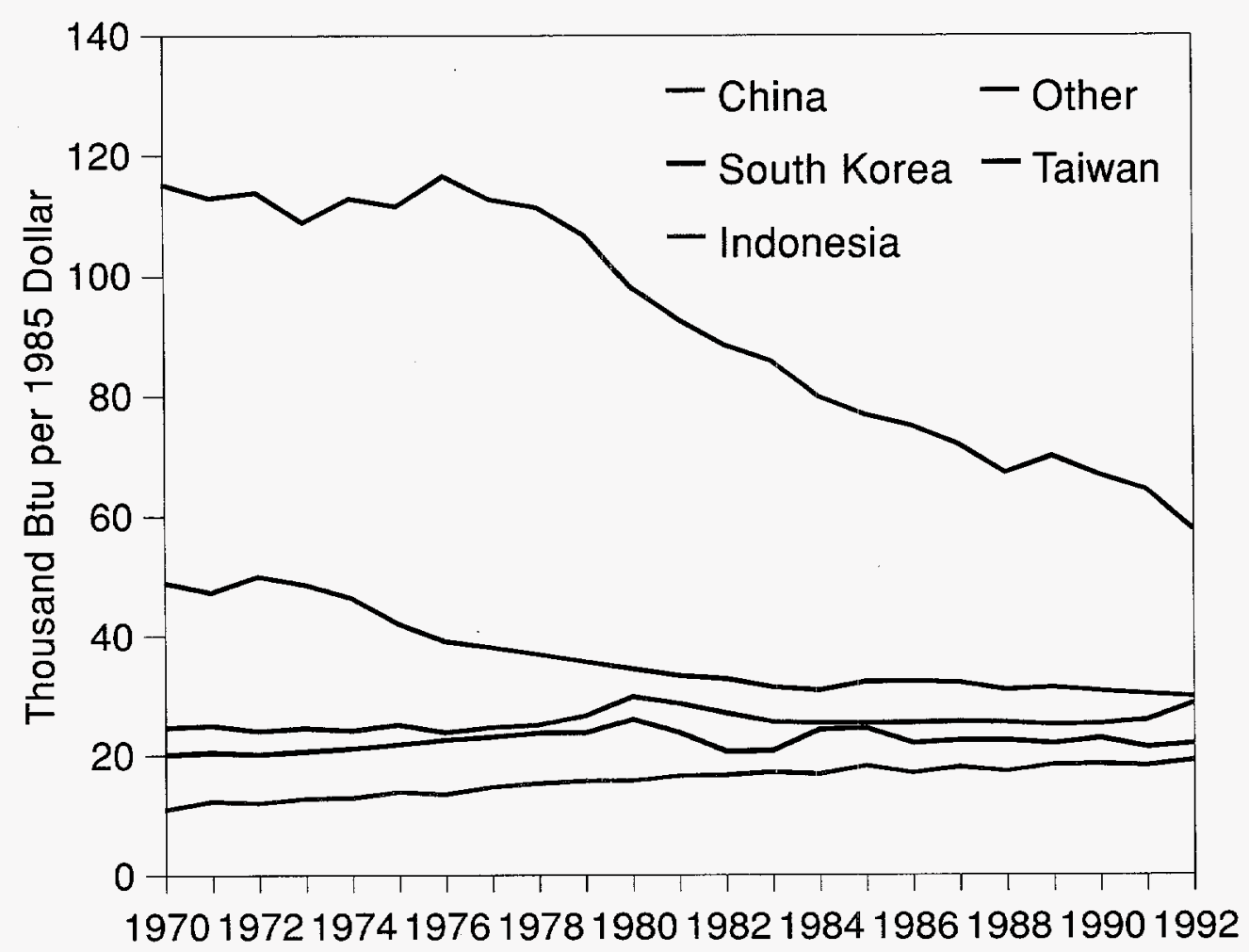

Source: See Appendix p. 55.

$\checkmark$ Led by China, energy consumption per constant dollar of GDP fell sharply in the Pacific Rim between 1970 and 1992. Overall, the Pacific Rim's energy intensity fell from 67,000 Btu per constant dollar of output in 1970 to $40,000 \mathrm{Btu}$ in 1992 .

$\checkmark \quad$ The dramatic decline in China's energy and carbon intensities between 1970 and 1992, larger than in the G-7 countries, resulted from a number of factors, including: 1) a shift away from central planning and towards more market-oriented economic policies under leader Deng Xiao-Ping beginning in the early 1980 's; 2) government programs to reduce energy consumption in state-owned industries; and 3) structural shifts in China's economy.

$\checkmark \quad$ Energy intensity in China, despite its dramatic decline since 1970, remains 2-3 times greater than in the OECD.

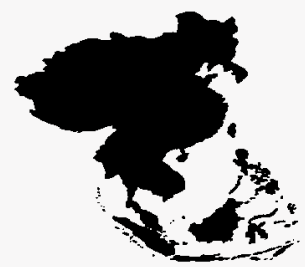




\section{Energy Consumption by Sector and Fossil Fuel and Total Energy Consumption}

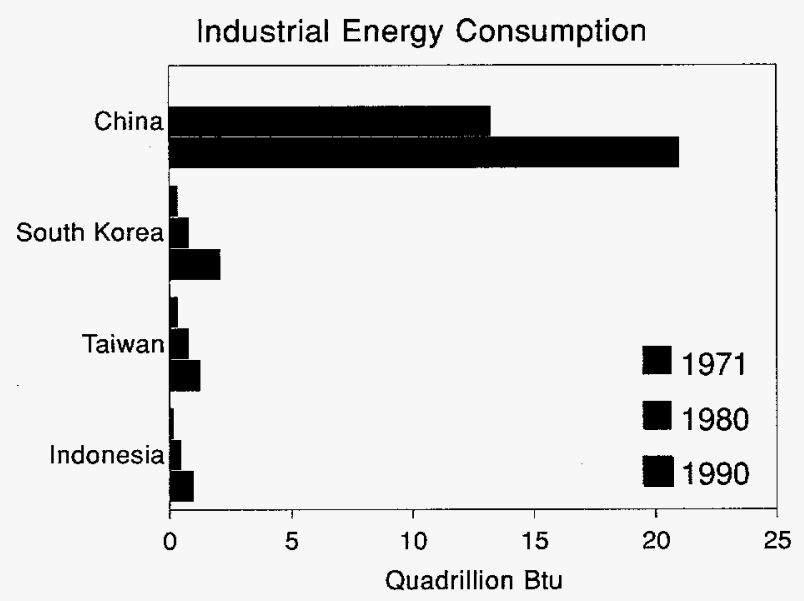

Note: Chinese sectoral data is not available for 1971 .

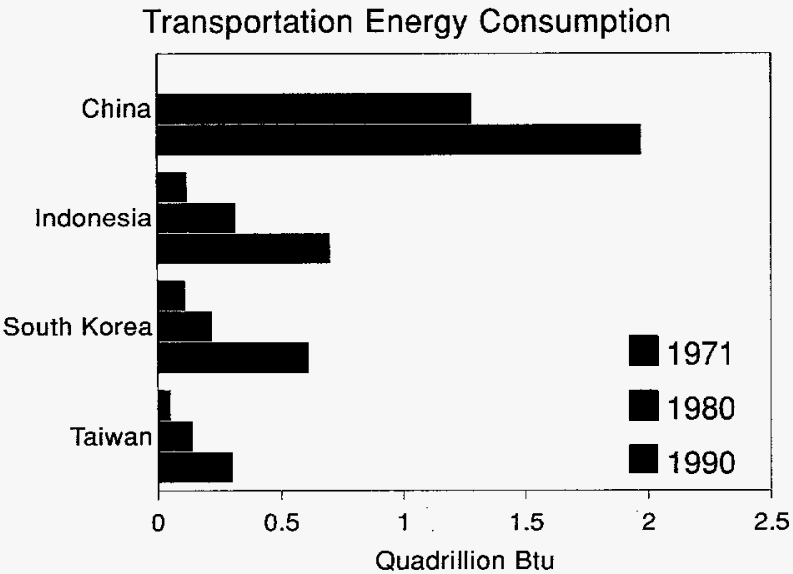

Note: Chinese sectoral data is not available for 1971 .

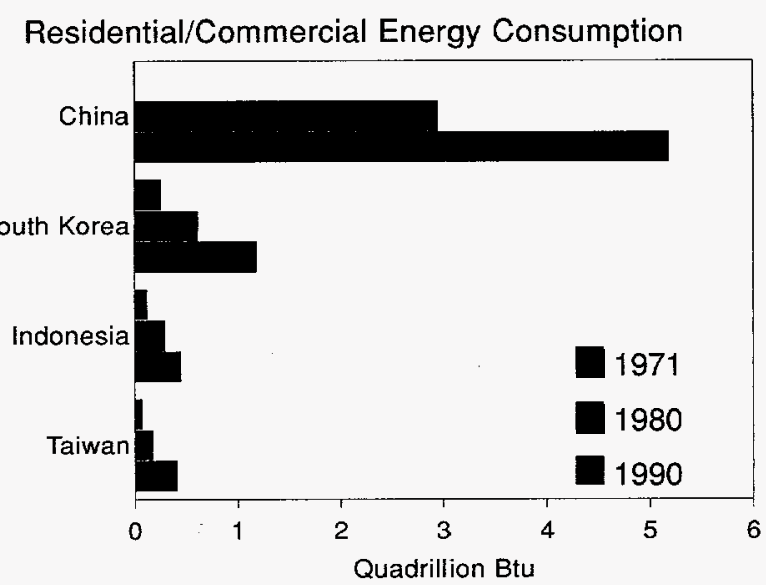

Note: Chinese sectoral data is not available for 1971.

\section{Fossil Fuel and Total Energy Consumption}

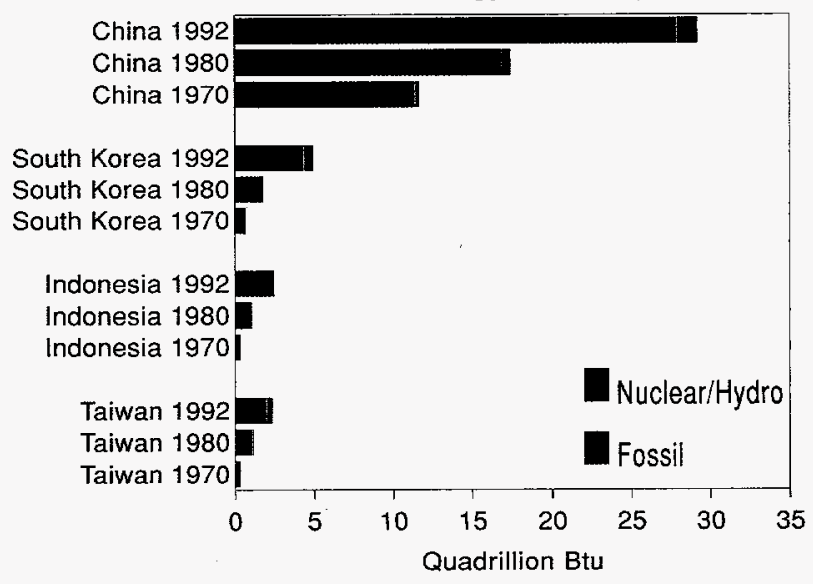

Note: The graphs cannot be directly compared because of differences in scale.

Source: See Appendix p. 56.

$\checkmark$ Pacific Rim energy consumption grew rapidly between 1970 and 1992, with industry accounting for the largest absolute share of this growth.

$\checkmark$ Energy consumption in the Pacific Rim is dominated by one sector in one country---the industrial sector in China. This sector alone consumed nearly half of Pacific Rim energy consumption in 1990. China's industrial sector consumed more energy in 1990 than all but two other countries' (the United States and FSU) total energy consumption.

$\checkmark$ Transportation and residential/commercial sectoral energy consumption grew rapidly, but still accounts for a relatively small share of total Pacific Rim energy consumption.

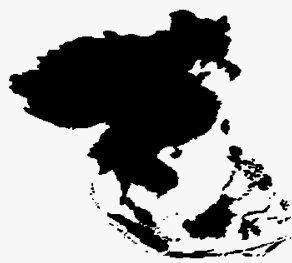




\section{Carbon Emissions by Sector and Fuel Type}

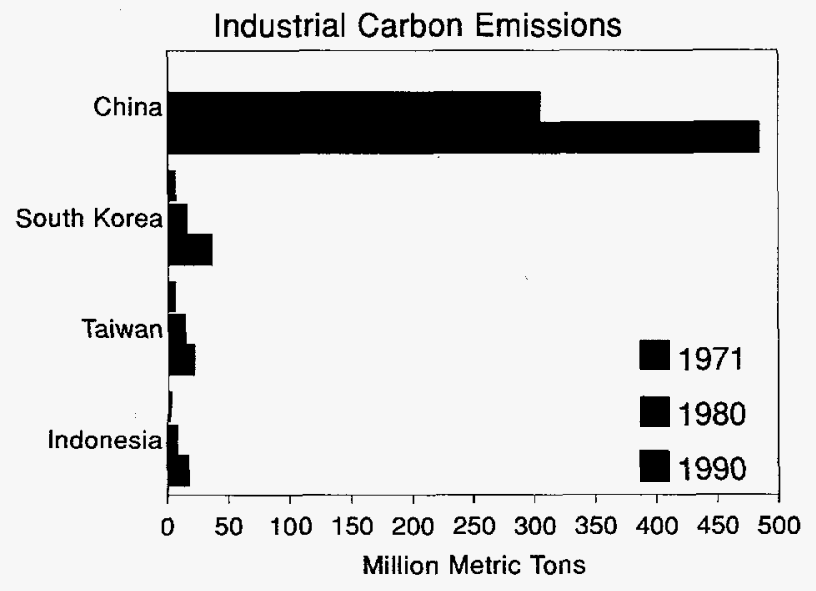

Note: Chinese sectoral data is not available for 1971.

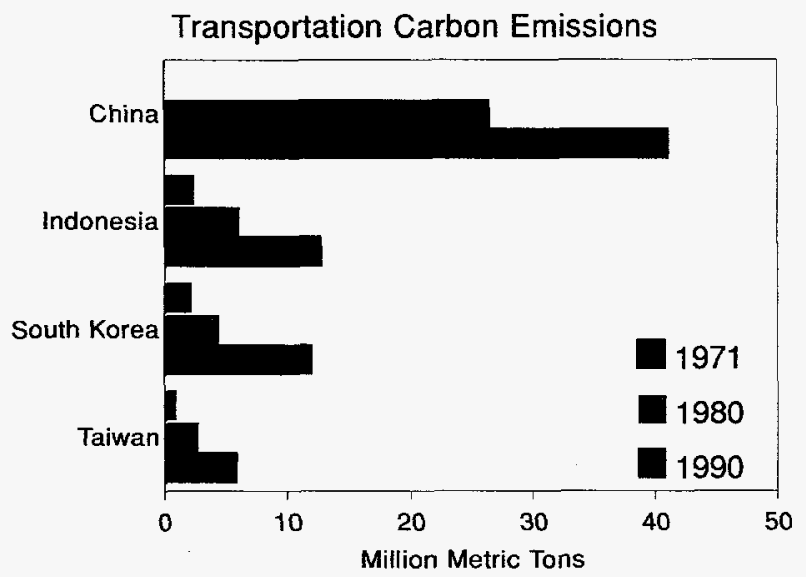

Note: Chinese sectoral data is not available for 1971

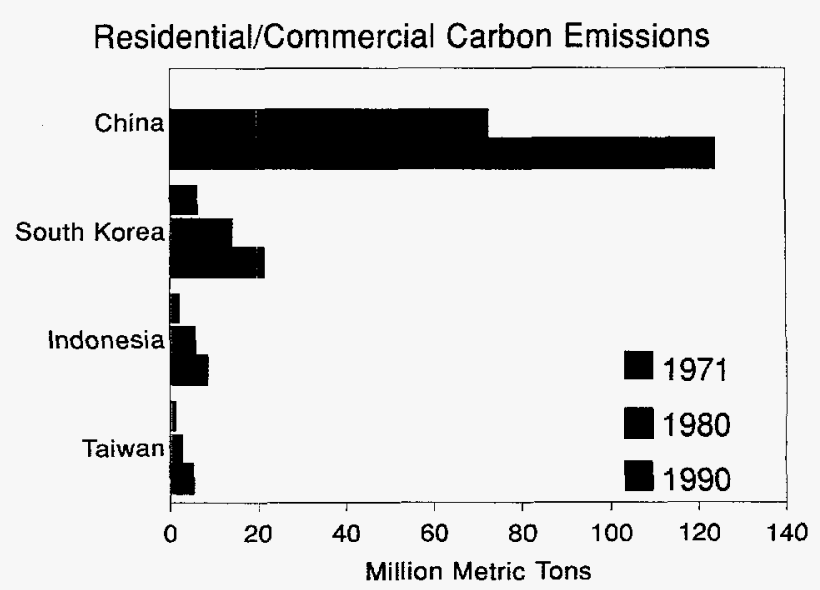

Note: Chinese sectoral data is not available for 1971.

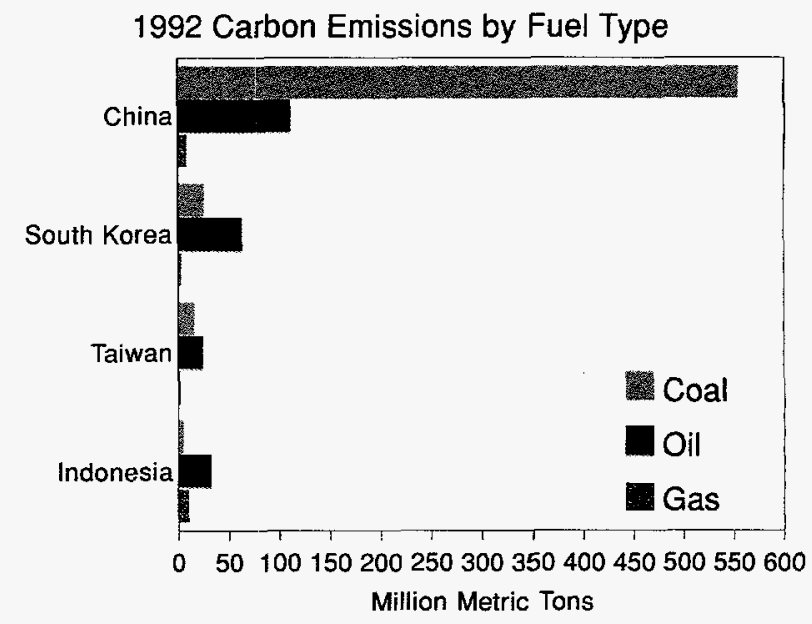

Note: The graphs cannot be directly compared because of differences in scale.

Source: See Appendix p.56.

$\checkmark$ Carbon emissions grew rapidly in all Pacific Rim sectors between 1971 and 1990.

$\checkmark$ Carbon emissions in Pacific Rim countries were dominated between 1971 and 1990 by the industrial sector, with residential/commercial and transportation emissions far behind.

$\checkmark$ The residential/commercial sector accounted for about 20 percent of the Pacific Rim's energy-related carbon emissions between 1980 and 1990, with transportation accounting for 11 percent.

$\checkmark$ Coal dominated carbon emissions in China, while oil dominated emissions elsewhere. Natural gas was virtually absent from China's fuel mix.

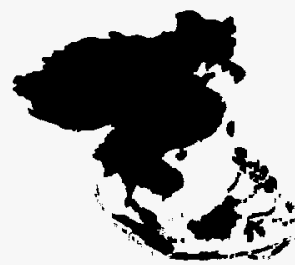




\section{Electricity Overview}
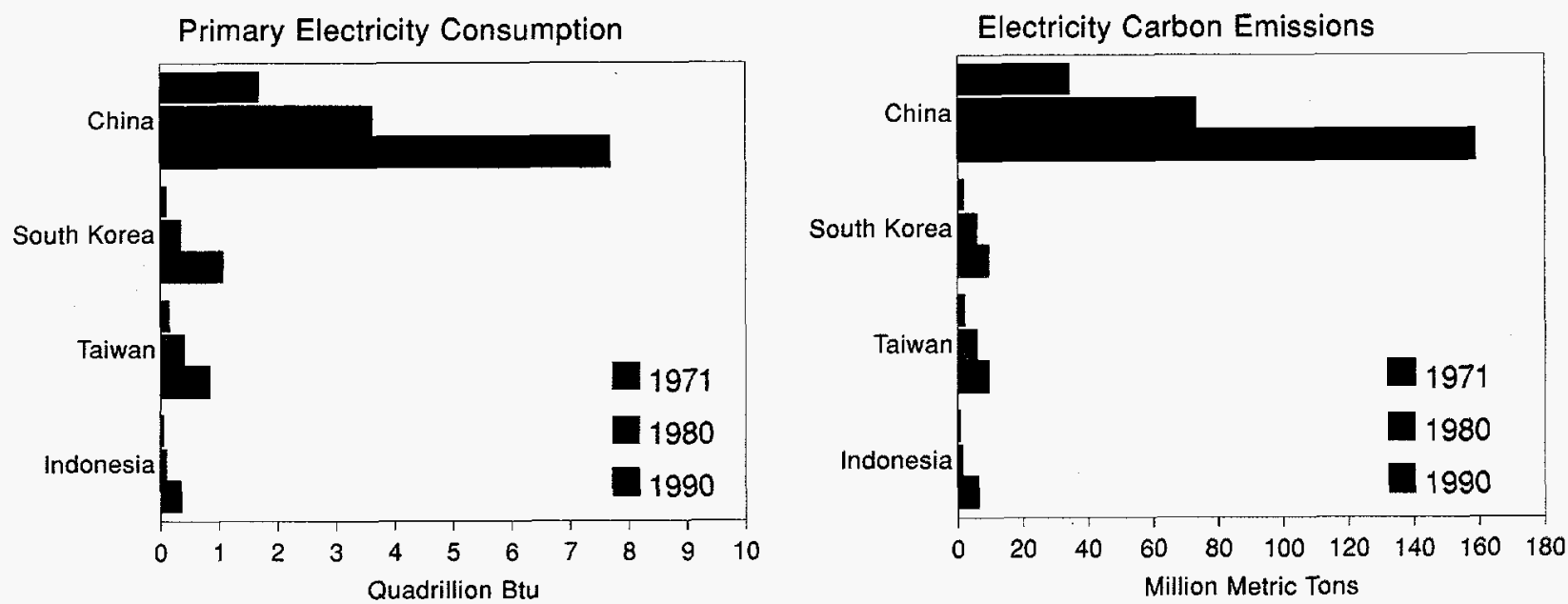

Source: See Appendix p. 56.

$\checkmark$ Electricity consumption in the Pacific Rim grew rapidly between 1971 and 1990, more than quadrupling during the period (from about 3 quadrillion Btu to 12 quadrillion Btu).

$\checkmark$ China's electric power sector accounted for the vast majority of this growth in electric power consumption.

$\checkmark$ China's electric power sector alone emitted 159 million tons of carbon in 1990, or 73 percent of the Pacific Rim's total carbon emissions from electricity generation.

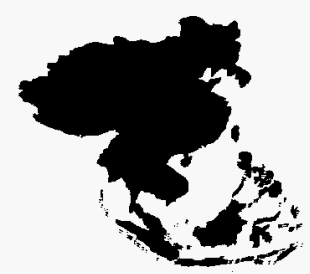




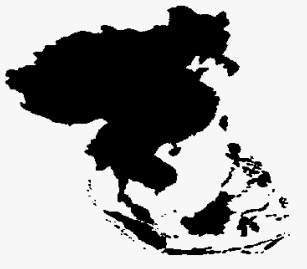




\section{Other Asia}

The purpose of this section is to provide information on differences in energy consumption and carbon emissions within the Other Asia region, consisting of two distinct subregions - South Asia and the Middle East. South Asia is dominated by India, a heavily populated country with low per capita income, low per capita energy consumption, and an energy economy reliant on coal, while the Middle East generally comprises several relatively small-sized oil exporters, with high per capita incomes, and high per capita energy consumption patterns.

Key findings of this section include:

$\checkmark$ Carbon emissions rose rapidly in Other Asia between 1970 and 1992. India, the Other Asia region's largest country, more than tripled its energy use and carbon emissions between 1970 and 1992. Major oil producing countries like Saudi Arabia and Iran also increased their carbon emissions during the period.

$\checkmark \quad$ Energy consumption per capita remained flat or rose slowly throughout most of the Other Asia region between 1970 and 1992. Two significant exceptions were the two major oil exporters, Saudi Arabia and the United Arab Emirates, which had the highest per capita energy consumption and carbon emissions in the world. India, although the largest energy consumer in the region, had by far the lowest energy consumption per capita.

$\checkmark \quad$ The close relationship between energy use and carbon emissions in this region resulted from the region's heavy reliance on fossil fuels, and to the relative absence of significant amounts of nuclear or hydroelectric power development. Coal consistently accounted for $40-50$ percent of Other Asia's fuel mix between 1970 and 1992 (led by India), compared to 30-40 percent for oil (led by the Middle Eastern oil exporters), about 10 percent for nuclear/renewables, and 10 percent or less for natural gas. Oil's share fell from 38 to 32 percent between 1970 and 1992, while natural gas grew from 3 to 13 percent.

$\checkmark$ Industrial sector consumption in Other Asia, led by India, almost doubled between 1980 and 1990 to about 10 quadrillion Btu. India accounted for about two-thirds of the region's industrial energy consumption in 1990. None of the countries in Other Asia consumed large amounts of energy for transportation, on an absolute basis. Except for India, transportation and residential/commercial were the most rapidly growing energy use sectors in Other Asia during the 1980's.

$\checkmark \quad$ Other Asian countries consumed 5.6 quadrillion Btu of energy for electricity generation in 1990, about the same level as Latin America but only 10 percent of G-7 levels. Electricity consumption in the region grew by 409 percent between 1971 and 1990 .

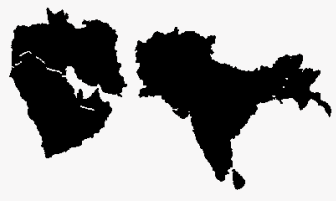




\section{Energy Consumption by Fuel Type and Energy-Related Carbon Emissions}

Fuel Use

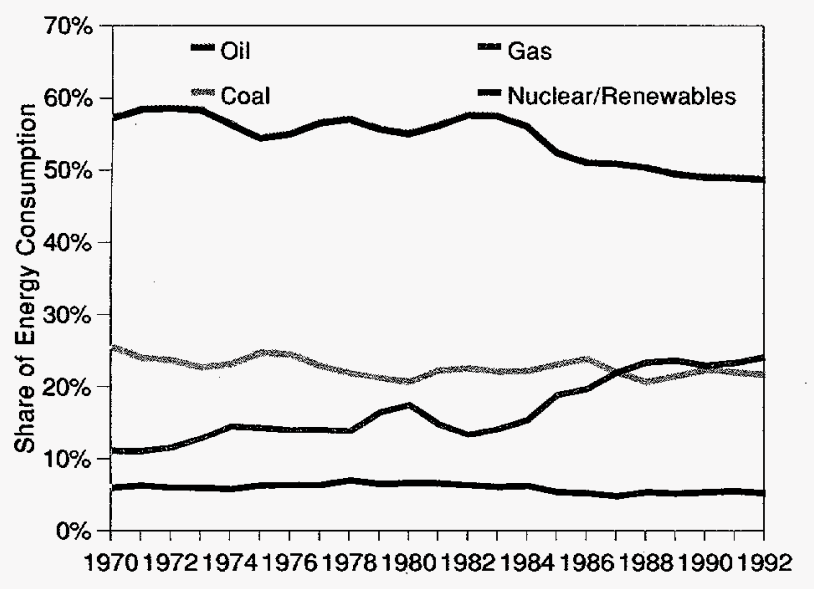

Carbon Emissions

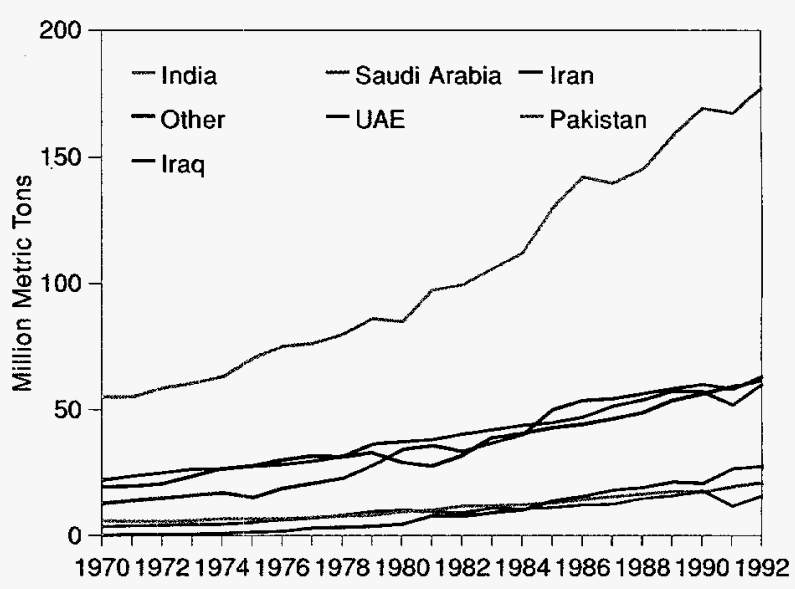

Source: See Appendix p.56.

$\checkmark$ Coal accounted for 40-50 percent of Other Asia's fuel mix between 1970 and 1992 (led by India), compared to 30-40 percent for oil (led by the Middle Eastern countries), about 10 percent for nuclear/renewables, and 10 percent or less for natural gas.

$\checkmark$ Carbon emissions rose rapidly in Other Asia between 1970 and 1992. The largest absolute growth was seen in India, which more than tripled its carbon emissions during the period (from 55 to 177 million metric tons).

$\checkmark$ Other Asia's reliance on oil fell from 57 to 49 percent between 1970 and 1992, while the share of natural gas grew from 11 to 24 percent. Most of this increase in the share of natural gas is due to major energy producers within the Persian Gulf---Saudi Arabia, the United Arab Emirates, and Iran.

Although India accounted for the largest single share of regional carbon emissions, major oil producing countries like Saudi Arabia and Iran also increased their carbon emissions sharply between 1970 and 1992.

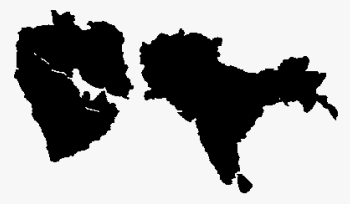




\section{GDP and Energy Consumption per Capita}
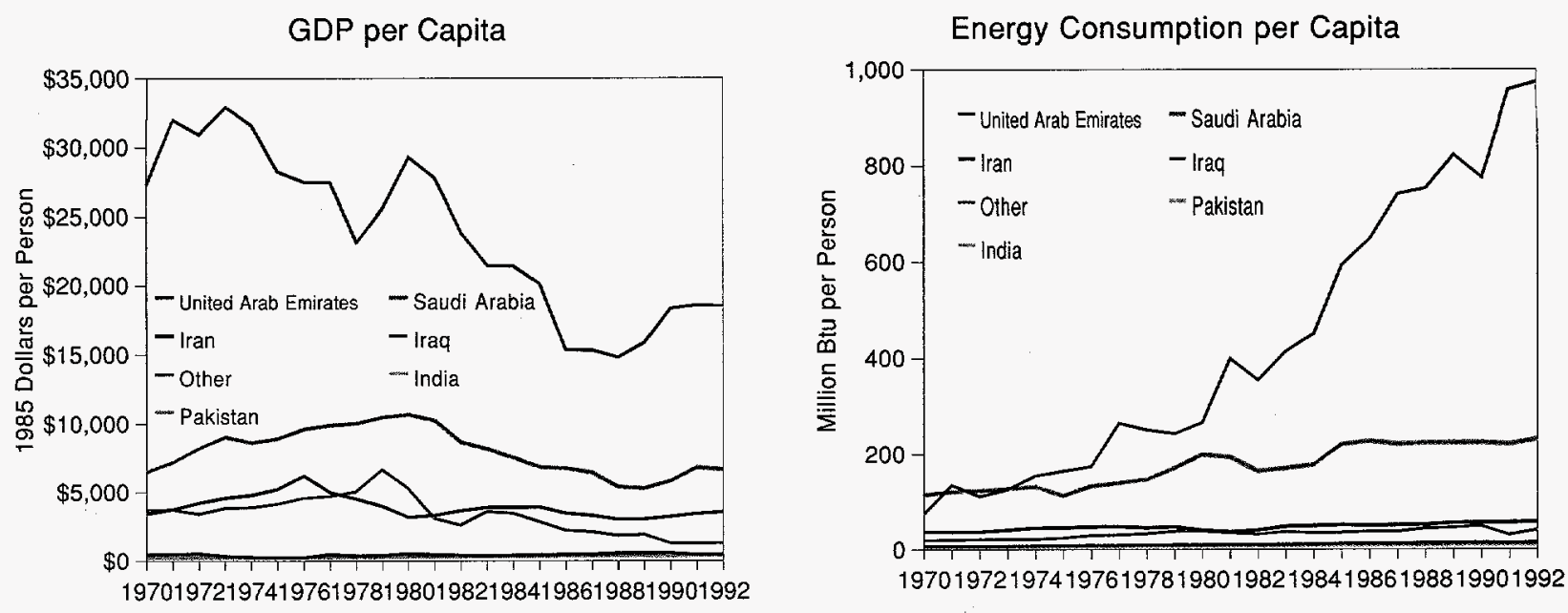

Source: See Appendix p.56.

$\checkmark \quad$ Other Asian GDP per capita displayed sharply different patterns between 1970 and 1992. India, by far the largest country in the region, showed a slow, steady increase in GDP per capita. Per capita GDP's in Middle East oil producers, however, tended to fluctuate along with oil prices.

$\checkmark \quad$ Per capita GDP's were much lower in South Asia than the Middle East. Saudi Arabia and the United Arab Emirates maintained per capita GDP's comparable or exceeding many OECD countries.

$\checkmark \quad$ Energy consumption per capita doubled in India and Pakistan between 1970 and 1992. Per capita energy consumption in other countries in the region grew less rapidly, with the significant exception of the United Arab Emirates, where it grew about six-fold.

$\checkmark$ Reflecting the energy intensity of its economy, energy consumption per capita in the United Arab Emirates is twice that of the United States and Canada.

Energy consumption per capita in Saudi Arabia rivals that of the FSU and most of the OECD countries.

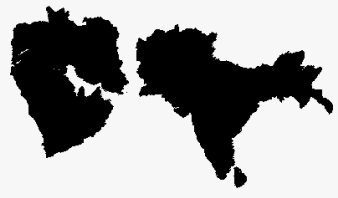




\section{Energy Consumption per Dollar of GDP}

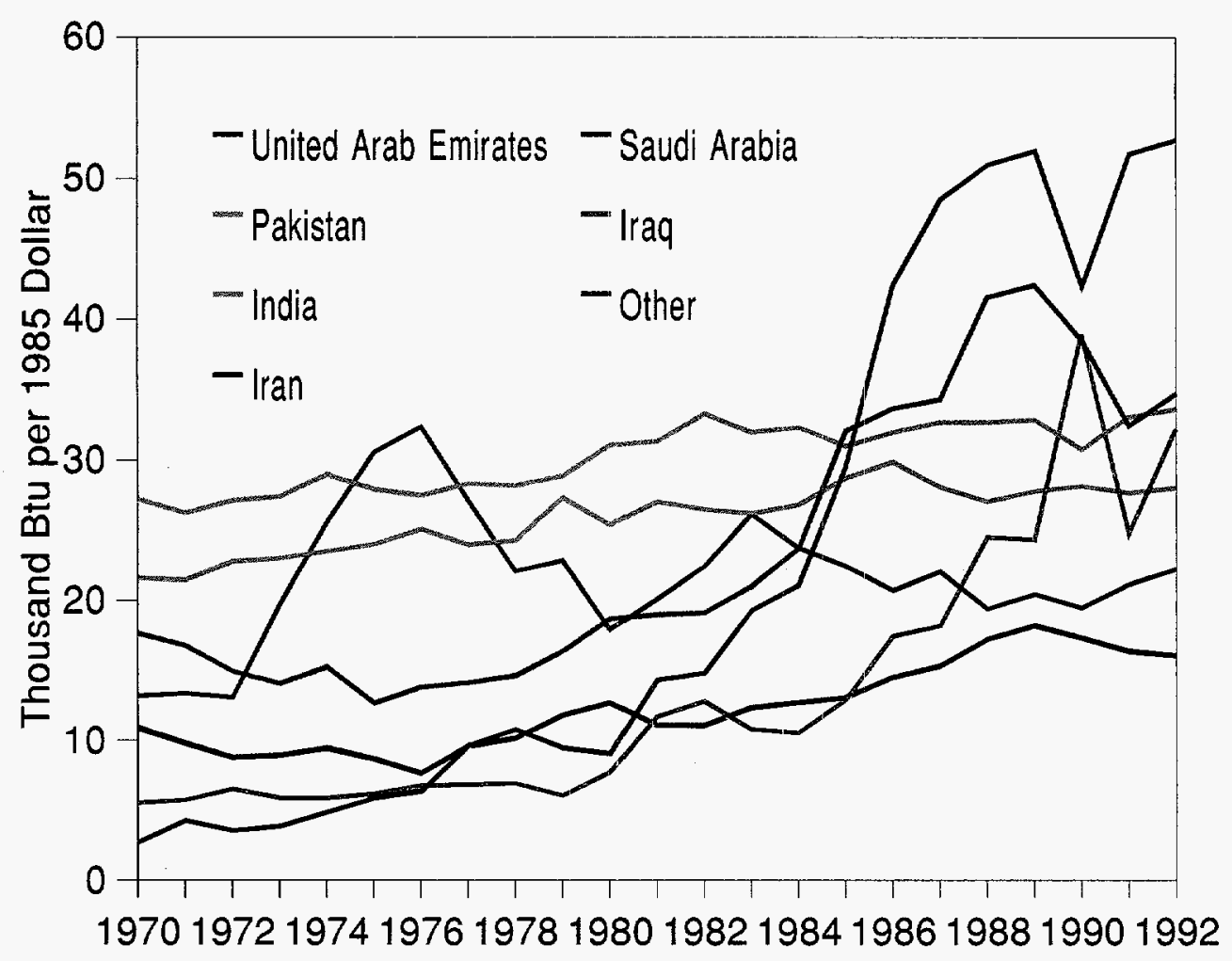

Source: See Appendix p. 56.

$\checkmark$ Other Asian energy intensity nearly doubled between 1970 and 1992, largely reflecting the development of energy intensive industries in rich, oil-producing countries like the United Arab Emirates and Saudi Arabia.

$\checkmark \quad$ Energy use per dollar of GDP grew more slowly in India and Pakistan than in oil-producing countries of Other Asia. 


\section{Energy Consumption by Sector and Fossil Fuel and Total Energy Consumption}

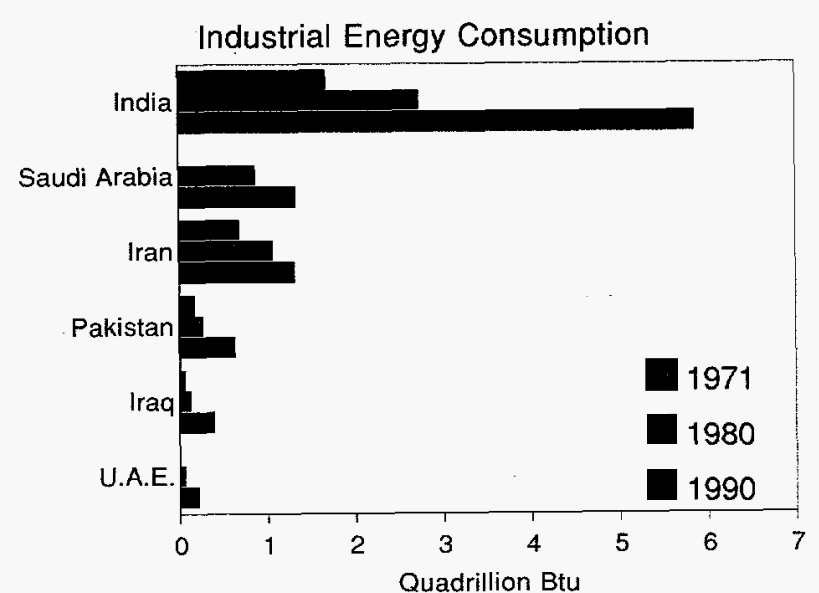

Note: Latest data used for lian (1989), Iraq (1988), Saudi Arabia (1986, with 1971 unavailable).

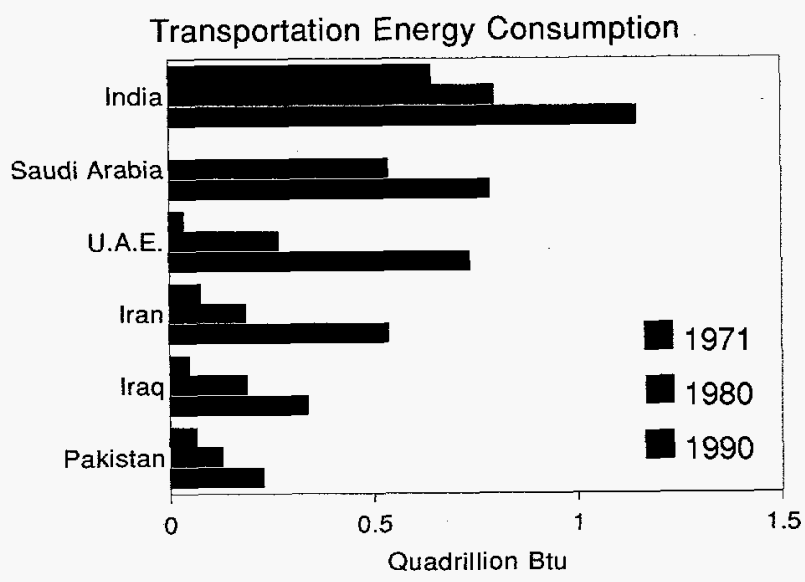

Note: Latest data used for Iran (1989), Iraq (1988), Saudi Arabia (1986, with 1971 unavailable).

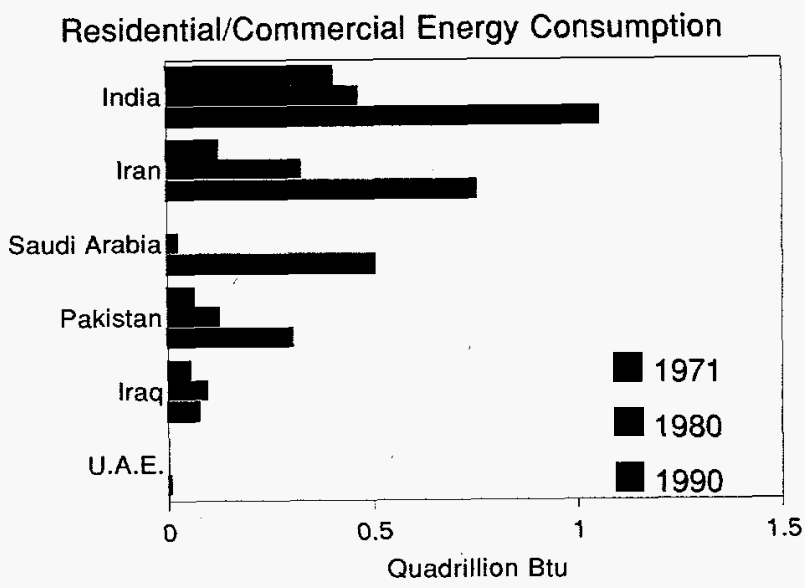

Note: Latest data used for lran (1989), Iraq (1988), Saudi Arabia (1986, with 1971 unavailable).

Fossil Fuel and Total Energy Consumption

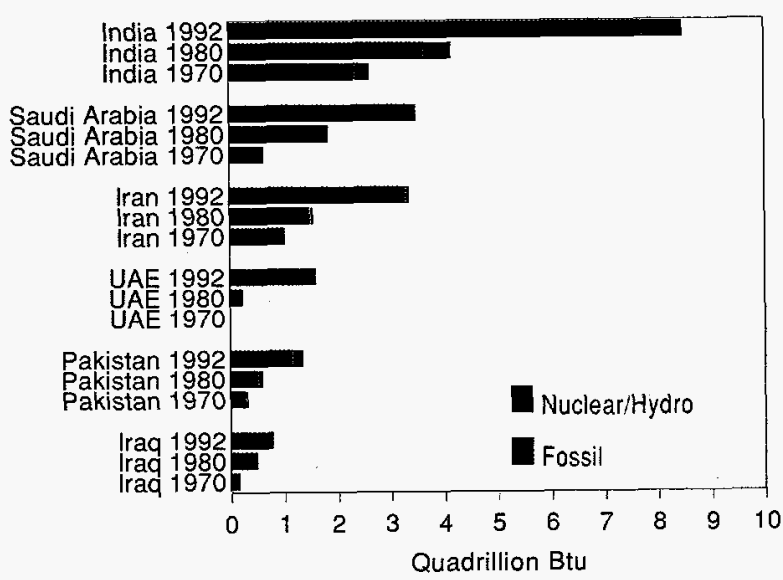

Note: The graphs cannot be directly compared because of differences in scale.

Source: See Appendix p.56.

$\checkmark$ Other Asian energy consumption was dominated by one country and one sector - Indian industry.

$\checkmark$ Other Asia's industrial energy consumption nearly doubled between 1980 and 1990, with India accounting for about 60 percent of Other Asian industrial energy consumption in 1990.

$\checkmark \quad$ The United Arab Emirates was the only country in the world where consumption in the transportation sector exceeded that in the industrial sector. The cargo port at Dubai is the 15 th largest in the world.

$\checkmark$ Outside of India, nuclear and hydroelectric power were virtually absent between 1970 and 1992.

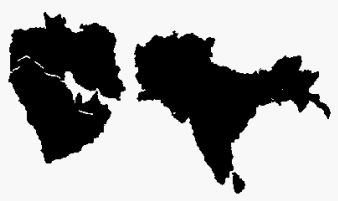




\section{Carbon Emissions by Sector and Fuel Type}
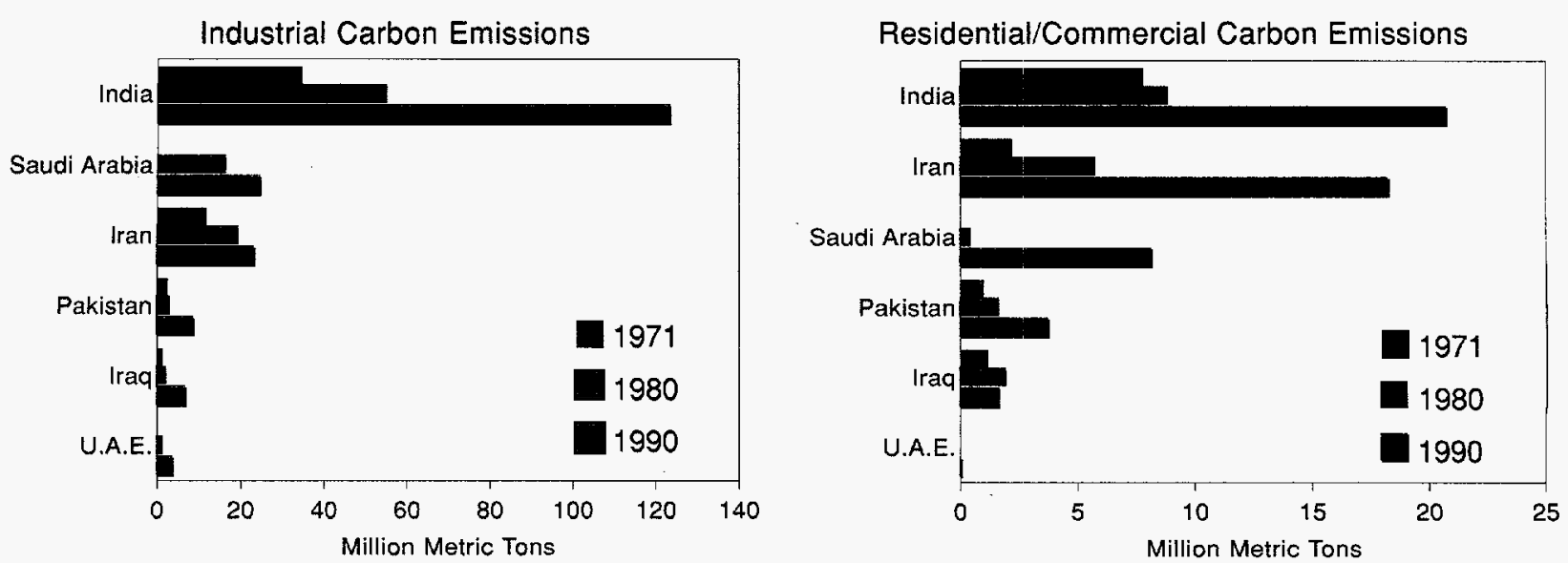

Note: Latest data used for Iran (1989), Iraq (1988), Saudi Arabia (1986; with 1971 unavailable). Note: Latest data used for Iran (1989), Iraq (1988), Saudi Arabia (1986, with 1971 unavailable).

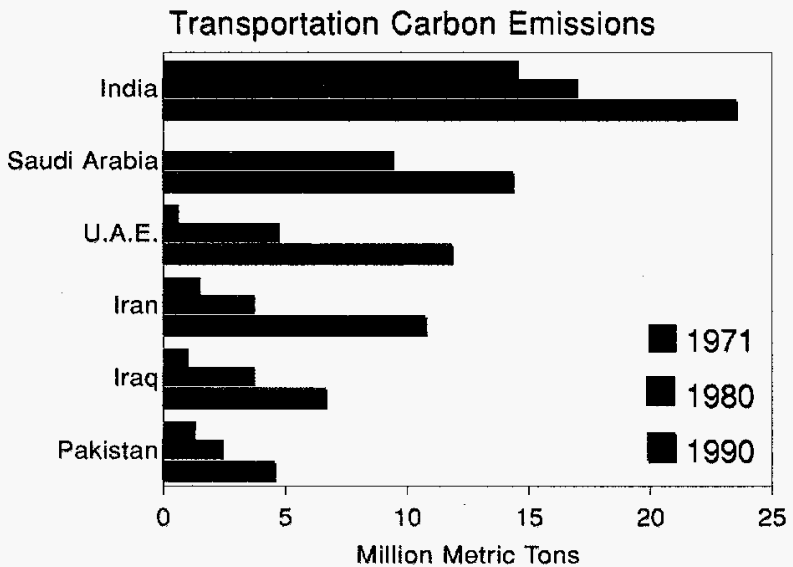

Note: Latest data used for Iran (1989), Iraq (1988), Saudi Arabia (1986, with 1971 unavailable).

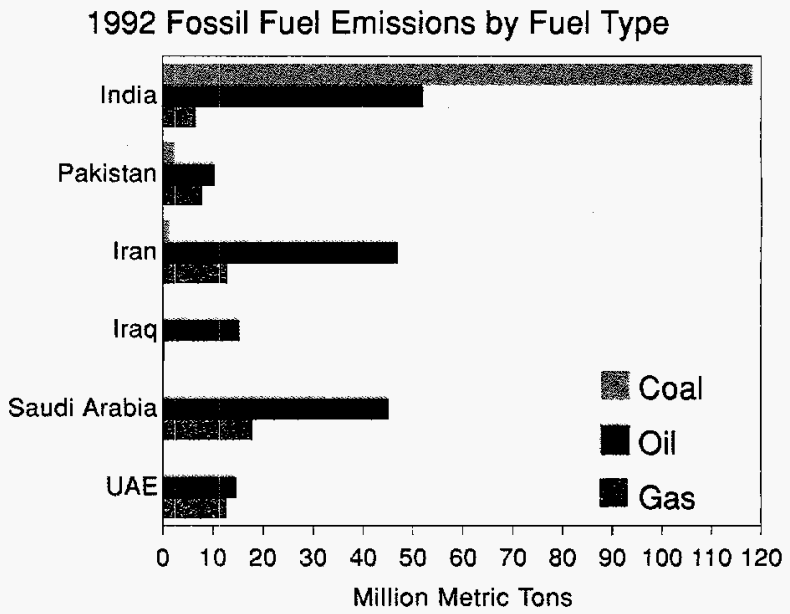

Note: The graphs cannot be directly compared because of differences in scale.

Source: See Appendix p. 56.

India's industrial sector emitted more carbon in 1990 than any G-7 country except for the United States and Japan.

$\checkmark$ Industrial sector carbon emissions in 1990 ranged from as little as 20 percent of national carbon emissions in the United Arab Emirates to over 70 percent in India.

$\checkmark$ Carbon emissions from Other Asia's residential/commercial sector rose rapidly between 1971 and 1990 , but remained small compared to industry.

$\checkmark \quad$ Coal dominates India's fossil fuel mix, while oil dominates elsewhere.

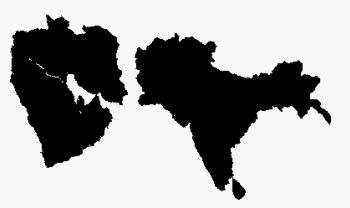




\section{Electricity Overview}
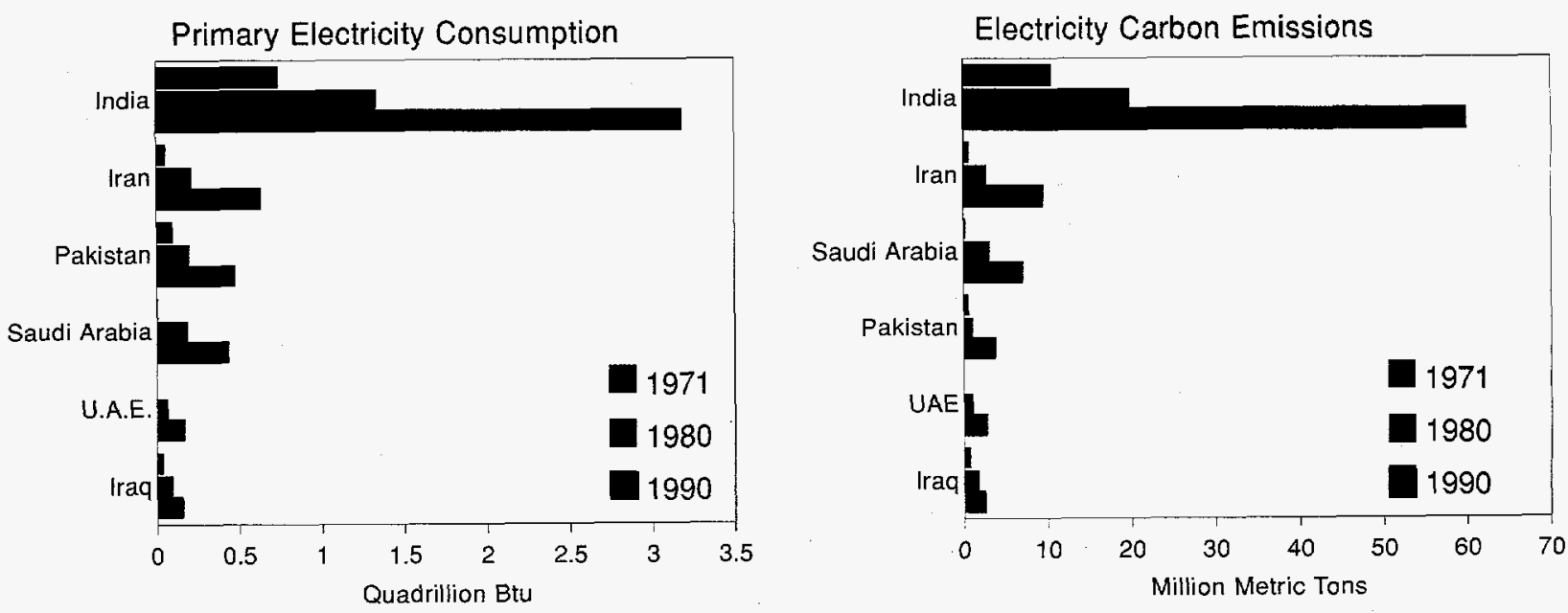

Source: See Appendix p. 57.

$\checkmark \quad$ Other Asia consumed 5.6 quadrillion Btu of energy for electricity generation in 1990, about the same level as Latin America but only 10 percent of G-7 levels.

$\checkmark$ Other Asian electricity consumption increased more than 400 percent between 1971 and 1990 .

$\checkmark$ Regional carbon emissions from electricity generation increased by over 600 percent from 1971-1990 to 101 million tons, a growth rate 40 percent faster than for the Pacific Rim, the next-fastest growing non-OECD region.

$\checkmark \quad$ Indian carbon emissions from electricity generation doubled between 1971-1980 and tripled again from 1980-1990 to 60 million tons, but still amounted to only 13 percent of U.S. carbon emissions from electricity generation.

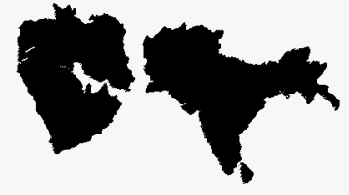




\section{Latin America}

The purpose of this section is to provide information on differences in energy consumption and carbon emissions within Latin America.

Key findings of this section include:

$\checkmark \quad$ Latin America consumed less energy per dollar of output than any other non-OECD region in 1992, while maintaining the second highest regional GDP per capita. In 1992, Latin America consumed 20 quadrillion Btu's of energy and emitted 296 million metric tons of carbon---less than any other non-OECD region except Africa. Latin American GDP per capita (about \$2,300 in 1992) is higher than any other non-OECD region except the FSU and Eastern Europe.

$\checkmark \quad$ Oil accounted for the largest share of Latin American energy consumption between 1970 and 1992, although its share eroded from over 70 percent in 1970 to under 60 percent in 1992 . The decline in oil's share was compensated for mainly by increases in the shares of nuclear/renewables and natural gas. Hydroelectric power, in particular, grew sharply during the period, and by 1992 accounted for more than 20 percent of Latin America's fuel consumption. Coal's share remained small (under 10 percent) between 1970 and 1992.

$\checkmark \quad$ Regional energy consumption per capita rose slowly between 1970 and 1992 . Venezuela, with the region's most highly developed oil industry, generally consumed energy at per capita rates more than twice the regional average. Énergy consumption per capita rose most rapidly in oil producing countries including Venezuela, Mexico, Colombia, and Brazil between 1970-1992.

$\checkmark \quad$ Regional carbon emissions were distributed more evenly compared to other non-OECD regions. However, carbon emissions from Mexico and Brazil grew rapidly between 1970 and 1992, and now represent the leading sources of Latin American emissions. Other significant Latin American carbon emitters include Venezuela, Argentina, and Colombia. These three countries combined emitted slightly less carbon in 1992 than did Mexico.

$\checkmark \quad$ Latin America's transportation and residential/commercial sectors accounted for the largest share of regional energy consumption in the non-OECD in 1990. Transportation and residential/commercial accounted for 28 percent and 21 percent of Latin American energy consumption in 1990 . Industry accounted for 50 percent, the lowest share in the non-OECD.

$\checkmark \quad$ Latin American electricity consumption grew rapidly between 1971 and 1990. Electricity grew from 19 percent of Latin American energy consumption in 1971 to 31 percent 1990, but still trailed the G-7's 1990 average of 38 percent.

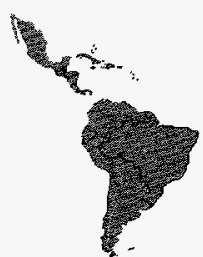




\section{Energy Consumption by Fuel Type and Energy-Related Carbon Emissions}
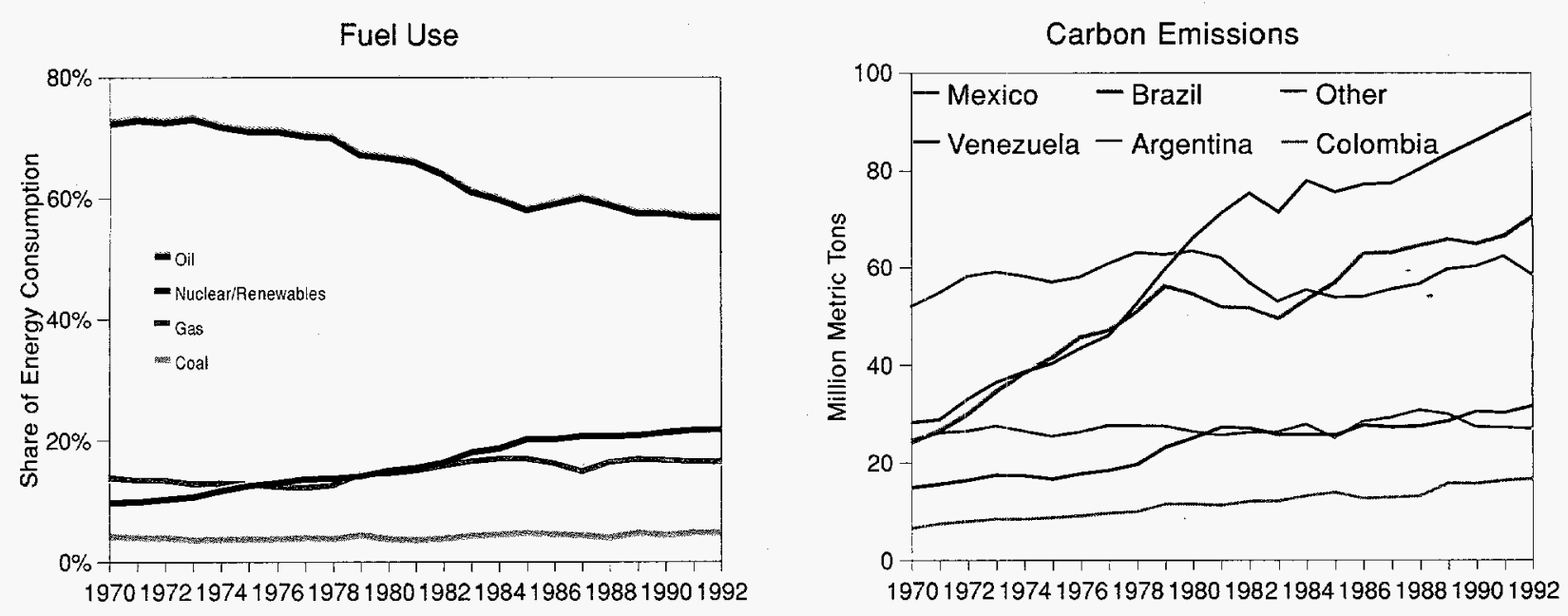

Source: See Appendix p. 57.

$\checkmark$ Oil accounted for the largest share of Latin American energy consumption, consistently, between 1970 and 1992. Oil's dominant share eroded, however, from over 70 percent in 1970 to under 60 percent in 1992.

$\checkmark \quad$ The decline in oil's share in the Latin American fuel mix was compensated for mainly by increases in the shares of nuclear/renewables and natural gas. Hydroelectric power in particular grew sharply during the period, and by 1992 accounted for more than 20 percent of Latin America's fuel consumption.

$\checkmark$ Coal's share remained consistently small (under 10 percent) between 1970 and 1992.

$\checkmark$ Between 1970 and 1992, Latin American carbon emissions tended to reflect a more even distribution pattern compared to other non-OECD regions, with no single country accounting for an overwhelming share of emissions.

$\checkmark$ Despite this, carbon emissions from Mexico and Brazil grew rapidly between 1970 and 1992, and now represent the leading sources of Latin American emissions.

$\checkmark$ Other significant Latin American carbon emitters include Venezuela, Argentina, and Colombia. These three countries combined emitted slightly less carbon in 1992 than did Mexico.

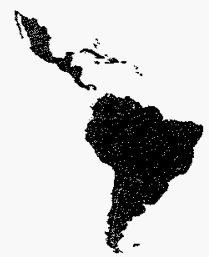




\section{GDP and Energy Consumption per Capita}
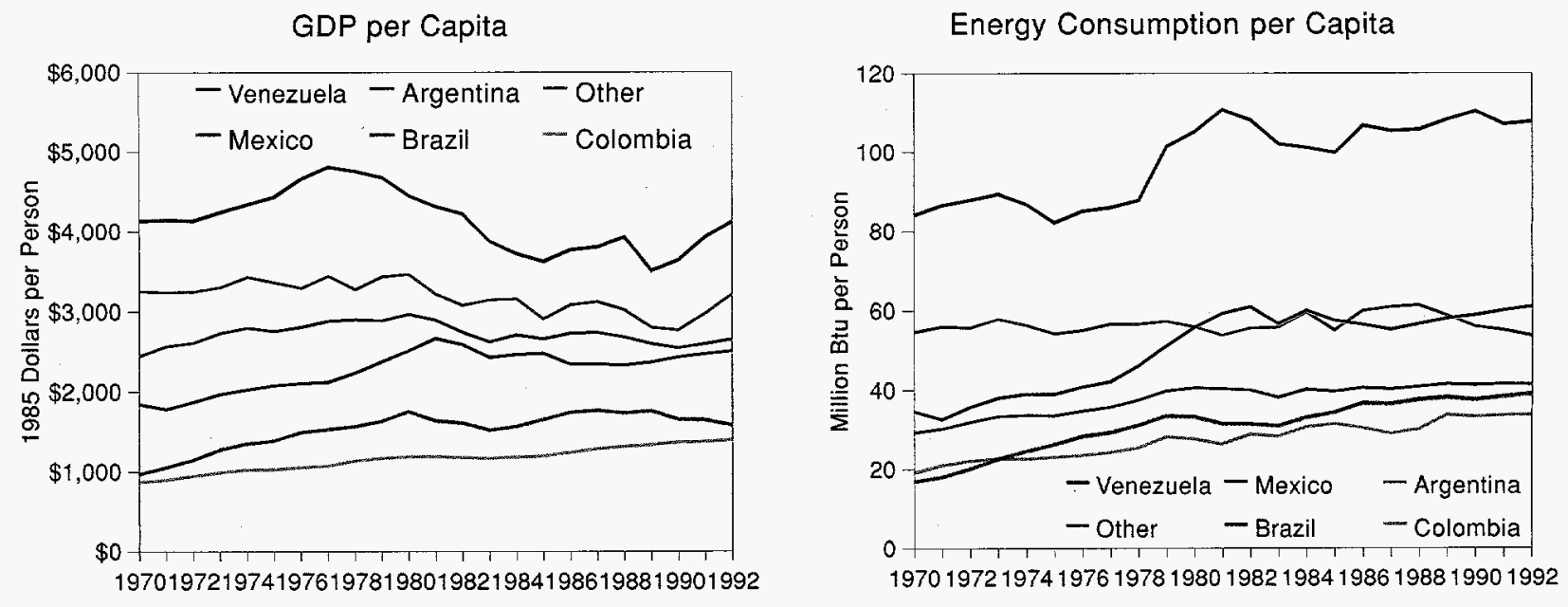

Source: See Appendix p. 57.

$\checkmark$ Latin American GDP per capita averaged about $\$ 2,300$ in 1992, higher than any other non-OECD region except for the FSU/Eastern Europe.

$\checkmark \quad$ As a whole, Latin American GDP per capita grew slowly between 1970 and 1992 . Venezuela consistently exhibited the highest per capita GDP levels throughout the period, while Colombia maintained the lowest.

$\checkmark$ Within the region, Mexico, Brazil, and Colombia showed growth in GDP per capita, while Venezuela and Argentina fell slightly.

$\checkmark \quad$ Latin American energy consumption per capita rose slowly along with per capita GDP between 1970 and 1992. Venezuela, with the region's most highly developed oil industry, generally consumed energy at per capita rates more than twice the regional average.

$\checkmark$ Energy consumption per capita rose most rapidly in oil producing countries like Venezuela, Mexico, Colombia, and Brazil between 1970 and 1992.

$\checkmark$ Despite this, average energy consumption per capita in Latin American oil producers remains far less, below levels exhibited by the United States or the FSU. 


\section{Energy Consumption per Dollar of GDP}

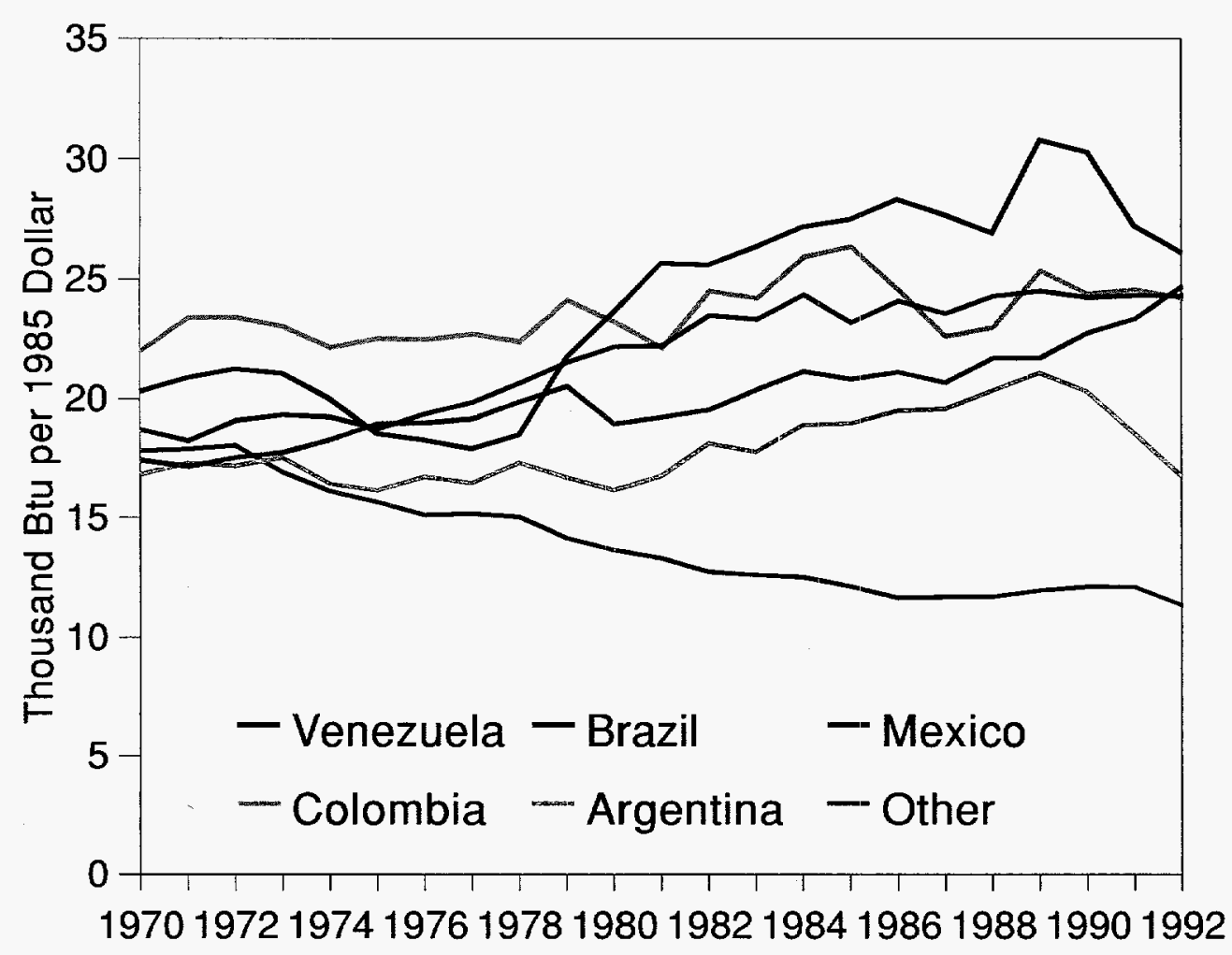

Source: See Appendix p. 57.

$\checkmark \quad$ Latin America consumed the least amount of energy per dollar than GDP of any non-OECD region in 1992.

$\checkmark \quad$ Latin American energy intensity rose only slightly between 1970 and 1992.

$\checkmark \quad$ Oil producing countries in Latin America generally increased their consumption of energy per dollar of GDP between 1970 and 1992, while the other countries of Latin America remained constant or fell. 


\section{Energy Consumption by Sector and Fossil Fuel and Total Energy Consumption}
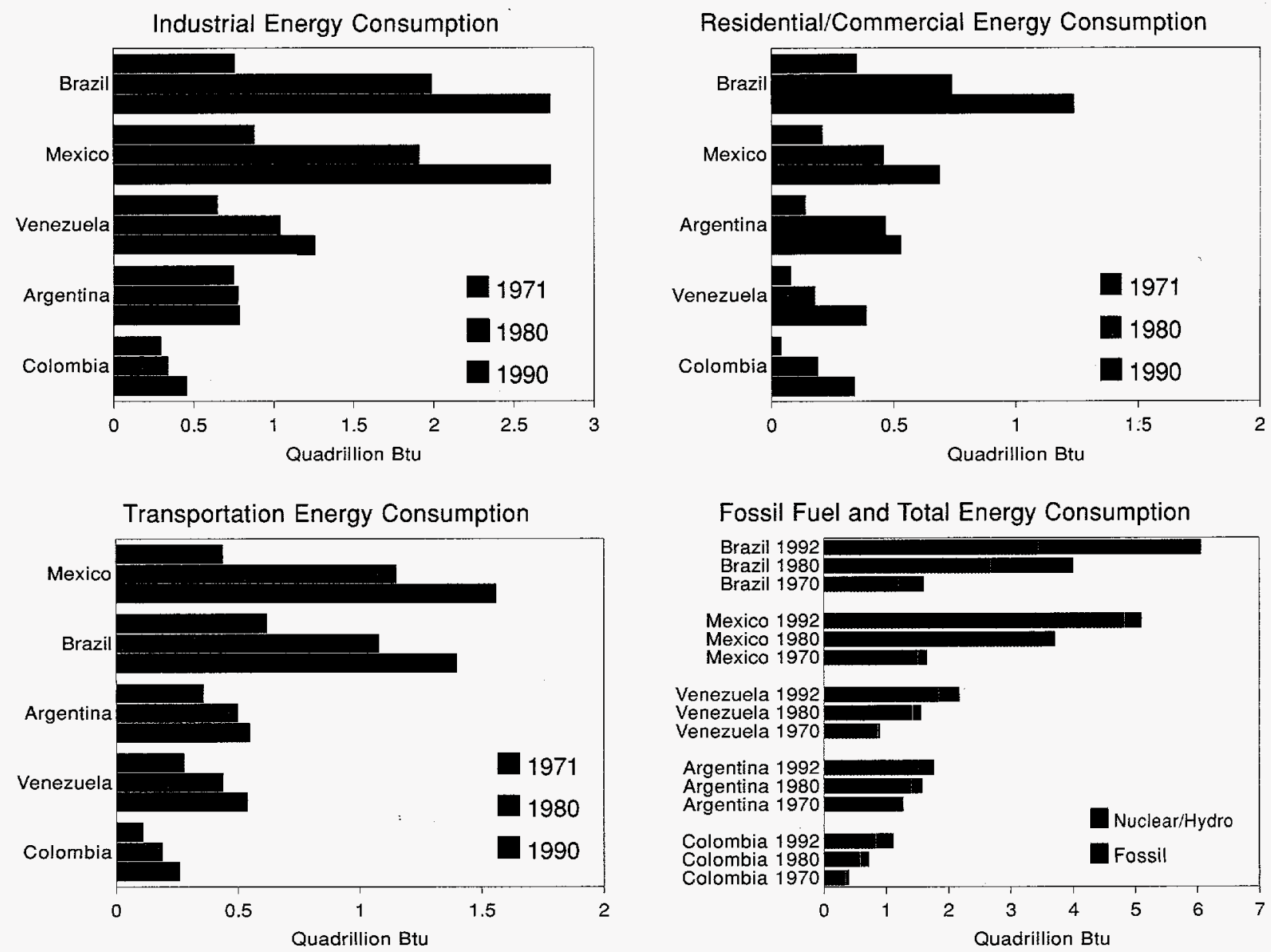

Note: The graphs cannot be directly compared because of differences in scale.

Source: See Appendix p. 57.

$\checkmark \quad$ Industry accounted for the largest single share of regional energy consumption between 1971 and 1990; however, industry's share was less than in any other non-OECD region.

$\checkmark$ Brazil and Mexico were the largest energy consumers in all sectors between 1971 and 1990 .

$\checkmark$ Energy consumption in all sectors and nearly all countries grew strongly between 1971 and 1990, with energy consumption growing most rapidly in Brazil and Mexico.

$\checkmark$ Hydroelectric power is particularly important in Latin America, making up a larger share of overall energy consumption than in any other non-OECD region.

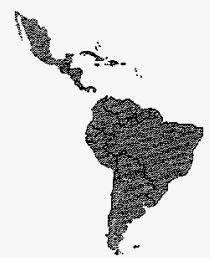




\section{Carbon Emissions by Sector and Fuel Type}
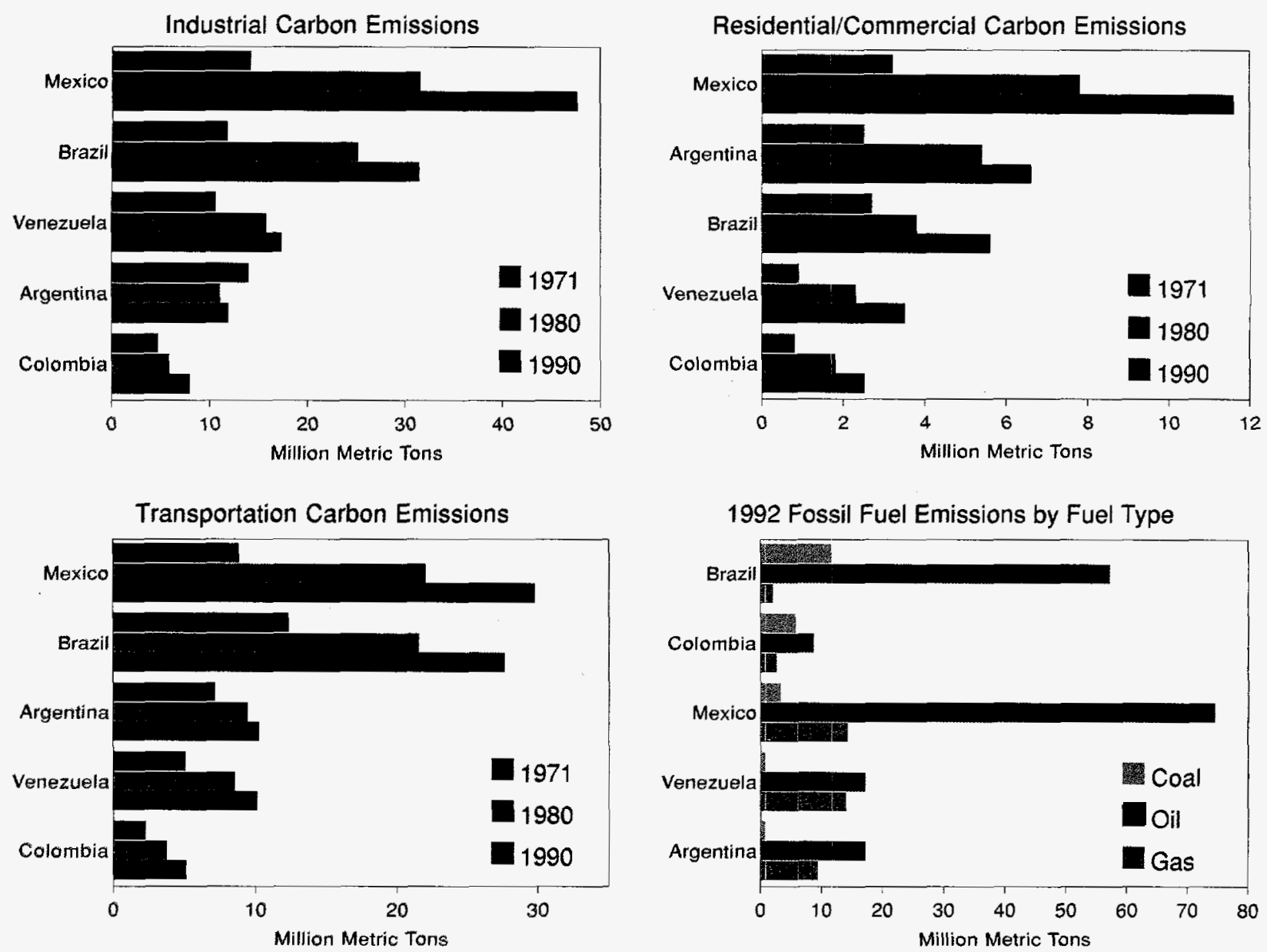

Note: The graphs cannot be directly compared because of differences in scale.

Source: See Appendix p. 57.

$\checkmark \quad$ Latin American carbon emissions, led by the industrial sector, rose rapidly from $1971-1990$.

$\checkmark \quad$ Industry accounted for the largest share of Latin American carbon emissions between 1971 and 1990, while residential/commercial accounted for, by far, the least.

$\checkmark \quad$ The largest carbon emitters in the industrial and transportation sectors were Brazil and Mexico. In the residential/commercial sector, Mexico, Argentina and Brazil ranked as the three largest.

$\checkmark$ Oil was the major fuel source for carbon emissions throughout the region, with natural gas second and coal third. 


\section{Electricity Overview}
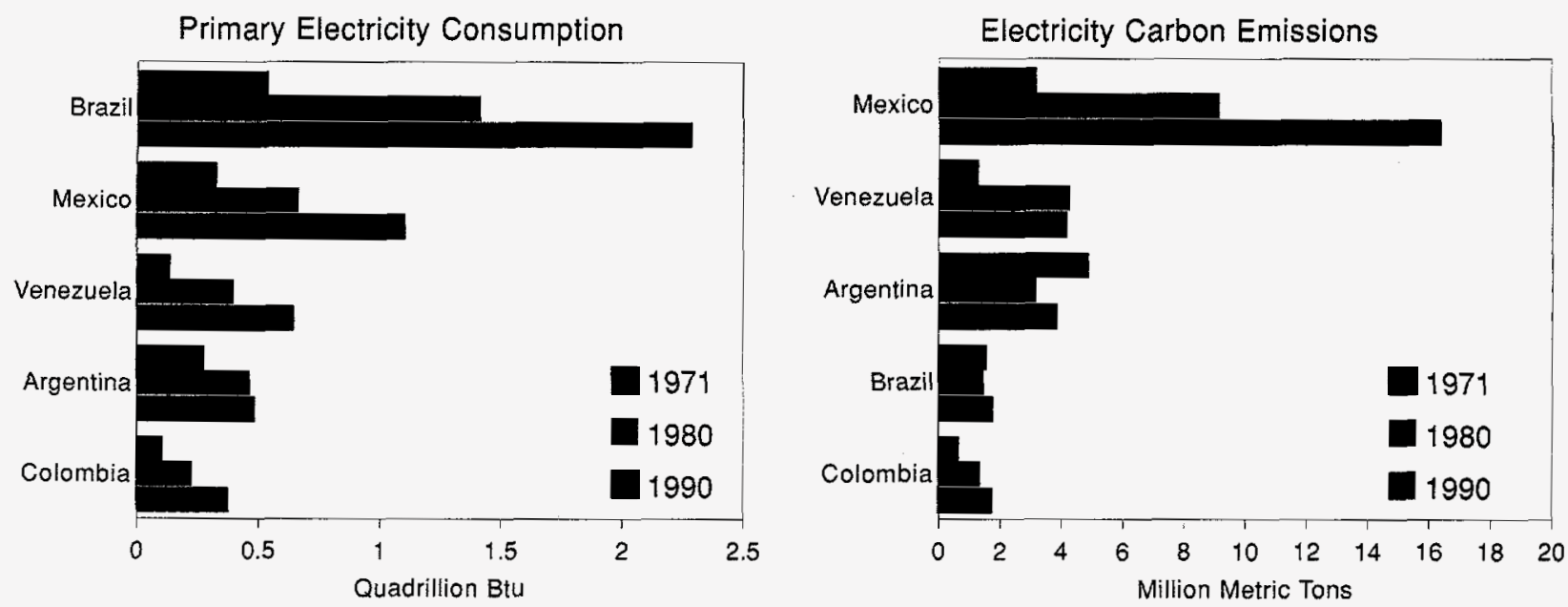

Source: See Appendix p. 57.

Total electricity consumption for Latin America in 1990 was 6 quadrillion Btu's, or one-fifth that of the United States. Among the top five Latin American countries, electricity consumption more than tripled between 1971 and 1990, from 1.4 quadrillion Btu to 4.9 quadrillion Btu.

$\checkmark$ Brazil consumed 2.3 quadrillion Btu of electricity in 1990, accounting for nearly 40 percent of Latin American electricity consumption in that year.

$\checkmark \quad$ Latin America's electric power sector emitted 36 million metric tons of carbon in 1990, less than any other non-OECD region. Latin America's relatively low level of carbon emissions from electricity generation is partly due to the region's heavy reliance on non-carbon-emitting hydroelectric power, which accounted for 21 percent of the region's electricity generation in 1992.

$\checkmark$ Brazilian carbon emissions from electricity generation were less than 2 million tons in 1990, compared with over 26 million tons for G-7 member, Italy. Italy which consumed about the same amount of electricity. This was largely due to the dominant role of hydroelectric power in Brazil's electric power sector.

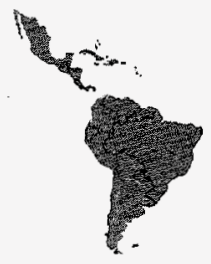




\section{Africa}

The purpose of this section is to provide information on differences in energy consumption and carbon emissions within Africa.

Key findings of this section include:

Africa consumes less energy and emits less carbon than any other non-OECD region. In 1992, Africa consumed 11 quadrillion Btu of energy and emitted 215 million metric tons of carbon---less than 20 percent as much as the FSU and Eastern Europe region. Between 1970 and 1992, Africa also consumed the least amount of energy per capita of any non-OECD region.

$\checkmark$ Oil and coal constitute the two main pillars of African energy supply. Combined, these two fuels accounted for about 80 percent of Africa's fuel mix in 1992. South Africa, in particular, is dependent upon coal for its energy needs. Northern and western Africa rely heavily on their large oil reserves.

$\checkmark \quad$ South Africa and Libya emitted by far the most carbon per person in Africa between 1970 and 1992. These two countries emitted carbon at rates roughly comparable with those of the European G-7 countries, but still less than half that of the United States.

$\checkmark$ South Africa accounted for the largest single share of African carbon emissions. Egypt, Nigeria, and Libya, producing significant amounts of oil, are the next largest carbon emitters in Africa.

$\checkmark \quad$ Africa was the only non-OECD region in which industry's energy share rose between 1971 and 1990. Industrial energy consumption rose rapidly during the 1970's and 1980's in three of the largest energy consuming nations of Africa---South Africa, Egypt, and Algeria.

$\checkmark \quad$ Carbon emissions from Africa's industrial sector also rose sharply between 1971 and 1990. Overall, industrial sector carbon emissions in the four largest African carbon emitters countries nearly tripled between 1971 and 1990, partly as a result of South Africa's heavy reliance on coal.

$\checkmark$ Despite this rapid growth, Africa's industrial carbon emissions remained relatively small. Only South Africa ranked among the world's largest industrial carbon emitters.

$\checkmark \quad$ Africa was by far the smallest electricity consumer among all of the non-OECD regions in 1990, and over half of Africa's electricity consumption was accounted for by South Africa. However, electricity consumption did expand rapidly in Africa between 1971 and 1990. 


\section{Energy Consumption by Fuel Type and Energy-Related Carbon Emissions}
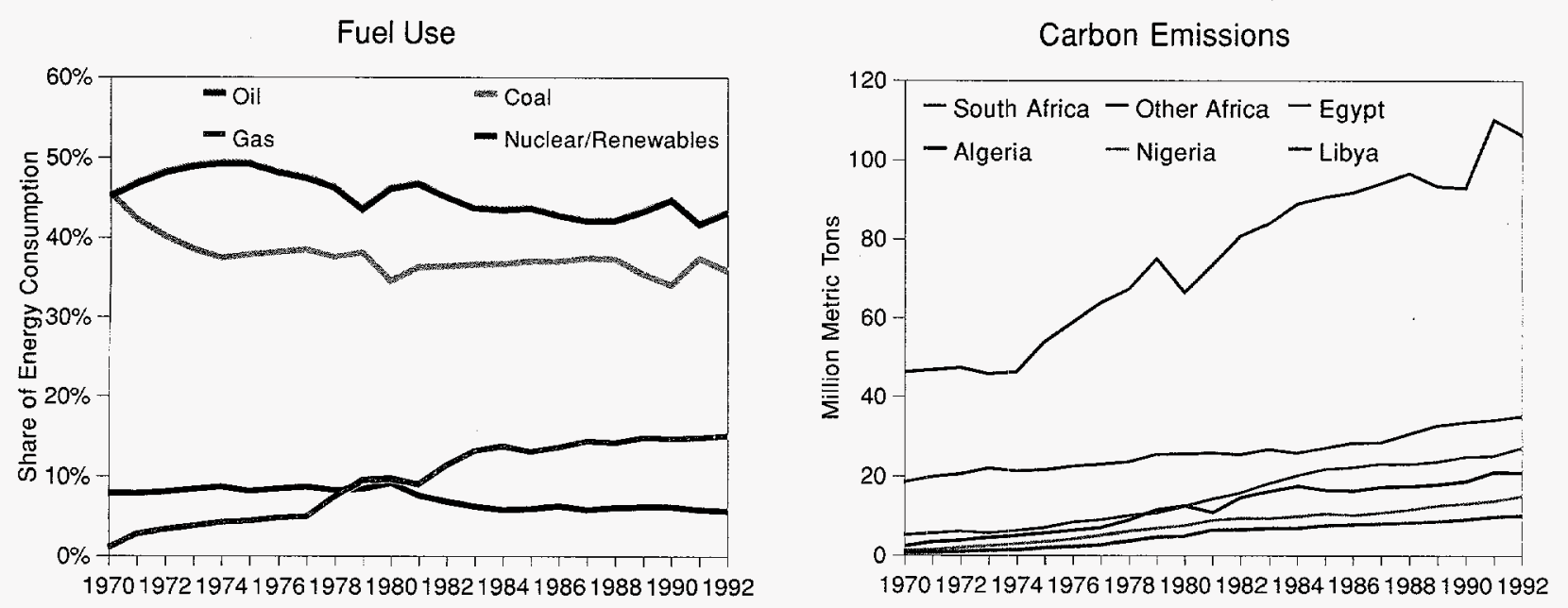

Source: See Appendix p. 57.

$\checkmark \quad$ Oil and coal constitute the two main sources of African energy supply. Combined, these two fuels accounted for about 80 percent of Africa's fuel mix in 1992.

$\checkmark$ South Africa, in particular, is dependent upon coal for its energy needs, while North and West Africa rely heavily on their large oil reserves.

$\checkmark \quad$ Natural gas consumption, although making up a relatively small share of African energy demand, increased substantially between 1970 and 1992. In fact, Africa consumed almost no natural gas in 1970. In contrast, by 1992, natural gas made up about 15 percent of Africa's fuel mix.

$\checkmark$ Nuclear/renewables accounted for about 5 percent or less of African commercial energy consumption between 1970 and 1992.

$\checkmark$ Carbon emissions rose sharply in Africa between 1970 and 1992, from 75 million metric tons to 215 million metric tons.

$\checkmark$ South Africa accounts for the largest single share of African carbon emissions. This is largely a result of its relatively advanced industrial economy, its extensive mining sector, and its heavy reliance on carbon-intensive coal. South Africa contains the seventh-largest coal reserves in the world.

$\checkmark$ Egypt, Nigeria, and Libya, all of which produce significant amounts of oil, are the next largest carbon emitters in Africa. These countries have large populations with relatively low incomes. Thus, although energy use per capita remains small, overall energy use is large.

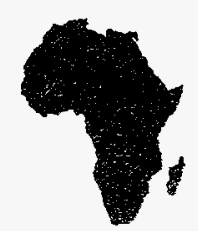




\section{GDP and Energy Consumption per Capita}
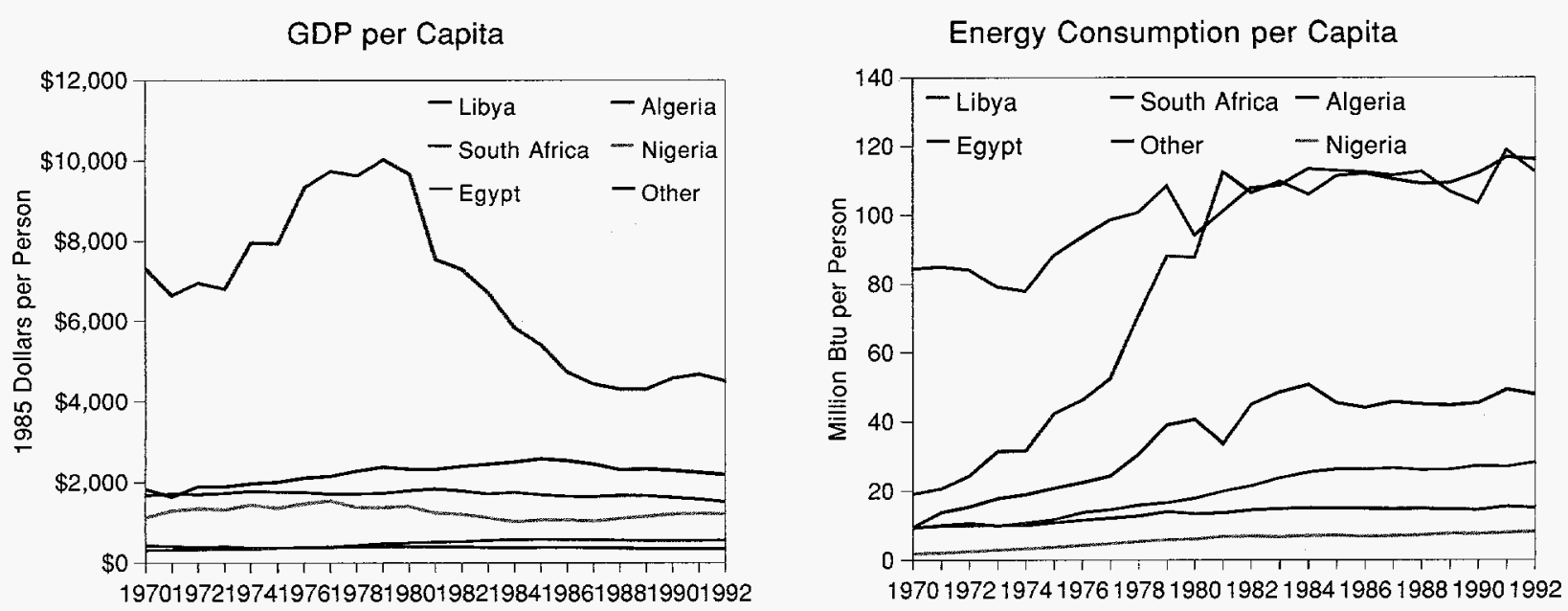

Source: See Appendix p. 58.

$\checkmark$ Africa maintained a per capita GDP in 1992 of approximately $\$ 650$, less than 5 percent of the U.S. per capita GDP.

$\checkmark \quad$ Unlike any other non-OECD region, African's per capita GDP actually fell slightly between 1970 and 1992, as GDP increases failed to keep pace with rapid population growth rates.

$\checkmark$ Most African countries are relatively non-industrialized and therefore consume relatively small amounts of commercial (i.e., oil, gas, coal, and electricity) energy per capita, relative to the rest of the world.

$\checkmark$ Industrialized and/or energy-producing countries (like South Africa, Libya, Algeria, and Egypt) generally consume more energy per capita than the rest of Africa. South Africa, with both a large economy and a highly developed energy industry, consumes the most energy per capita in Africa.

$\checkmark$ Libya, Algeria, and Egypt increased their energy consumption per capita, substantially, between 1970 and 1992.

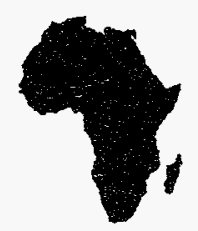




\section{Energy Consumption per Dollar of GDP}

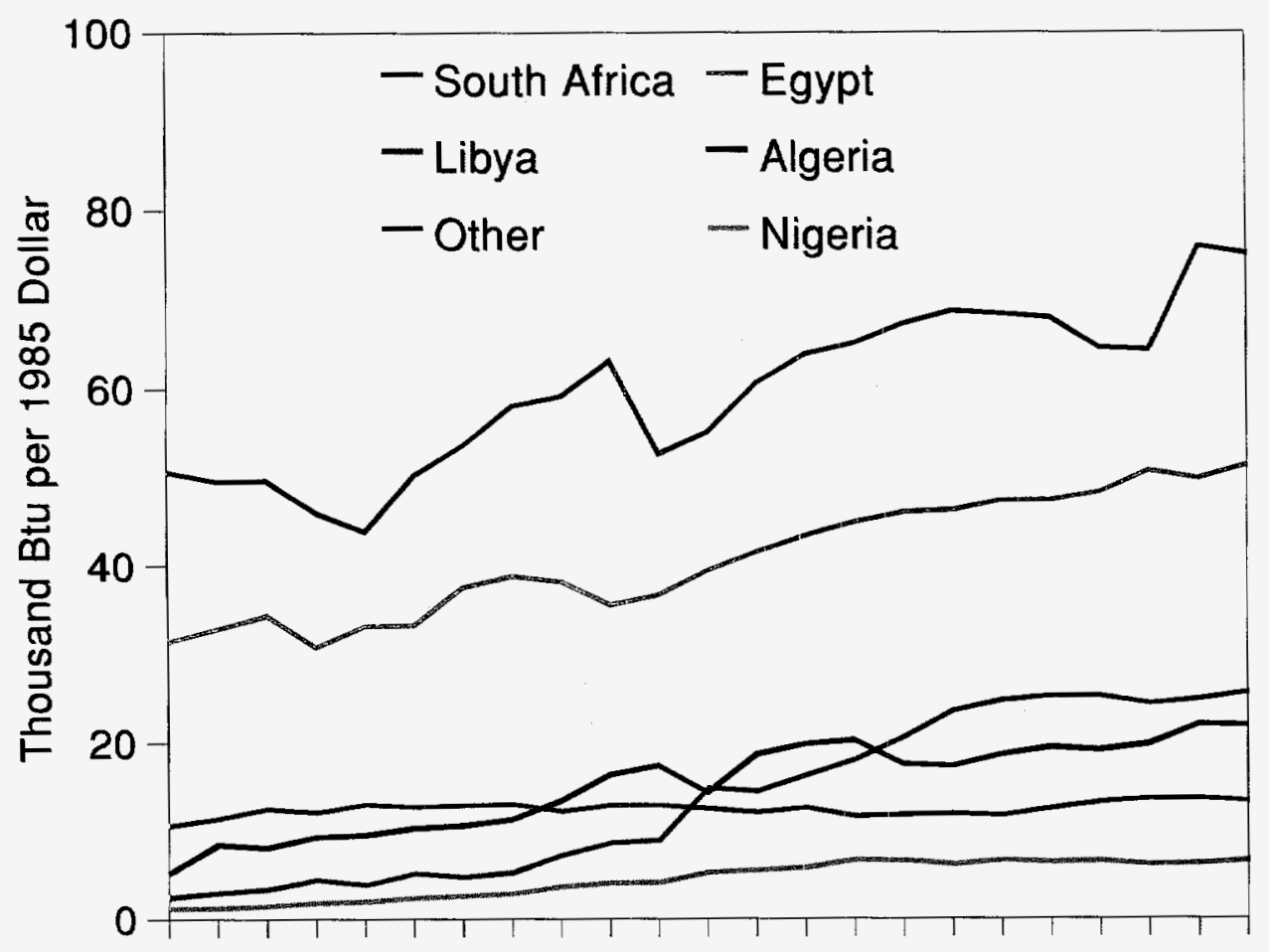

197019721974197619781980198219841986198819901992

Source: See Appendix p. 58.

$\checkmark$ Africa's energy consumption per dollar of GDP slowly increased between 1970 and 1992, in contrast to the G-7 countries, where energy intensity declined by almost a third over the same period.

$\checkmark$ South Africa and Egypt consumed the most energy per dollar of GDP among major energy consumers in Africa. Egypt consumed energy at more than twice the rate per dollar of GDP as Canada, the most energy-intensive G-7 country. South Africa consumed energy at more than three times Canada's per dollar rate.

$\checkmark \quad$ Nigeria was the least energy intensive country among major African energy consumers. In 1992, for example, Nigeria used less than 10 percent of the energy to produce a unit of GDP as South Africa.

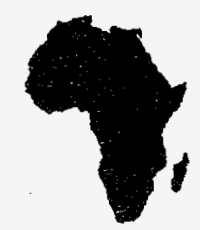




\section{Energy Consumption by Sector and Fossil Fuel and Total Energy Consumption}

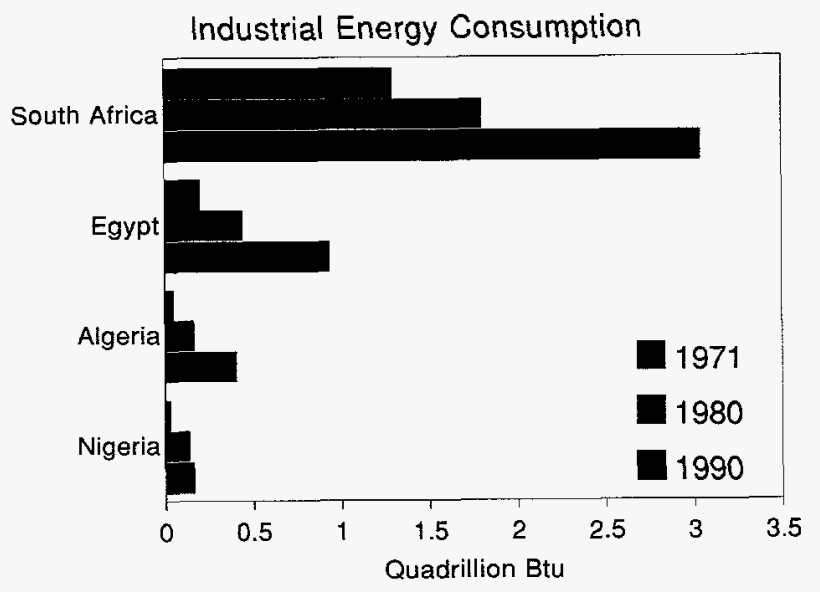

Note: Libyan sectoral data is not available; latest avaliable data (1988) used for Algeria.

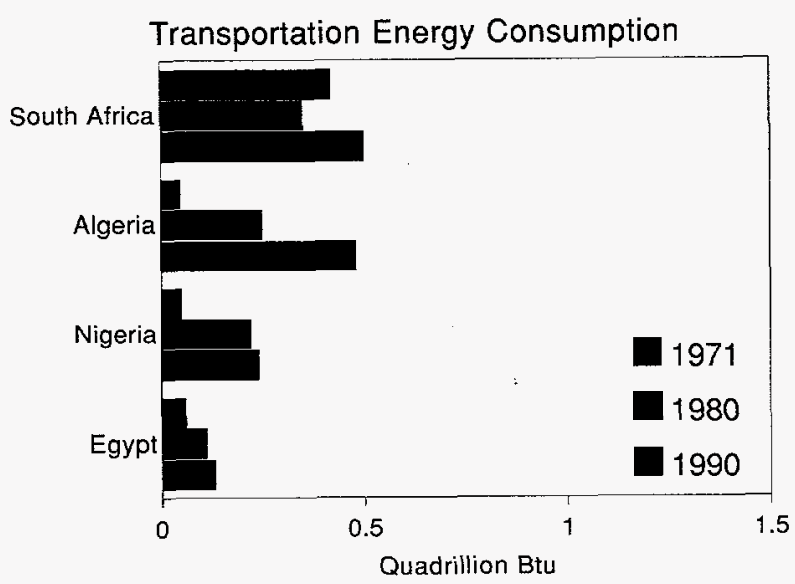

Note: Sectoral data not available for Libya; latest data (1988) used for Algeria.

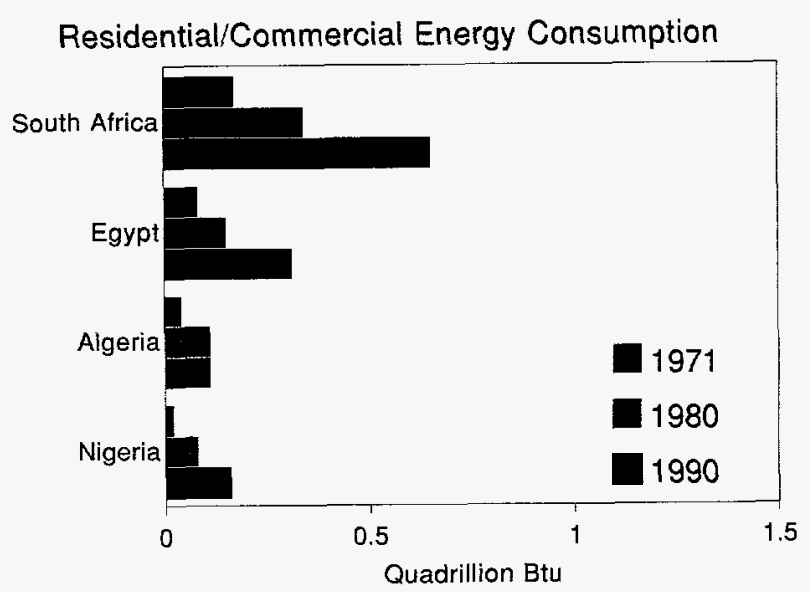

Note: Libyan sectoral data is not available; latest data (1988) used for Algeria.

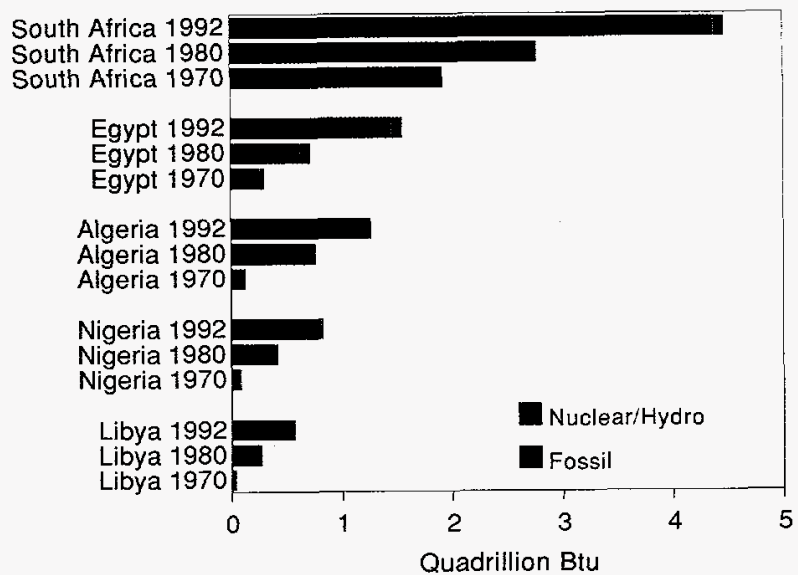

Note: The graphs cannot be directly compared because of differences in scale.

Source: See Appendix p. 58.

$\checkmark$ African energy consumption was dominated by the most industrialized country -- South Africa.

$\checkmark$ Africa's industrial sector accounted for the largest share of regional energy consumption.

$\checkmark$ Energy consumption in Africa's transportation and residential/commercial sectors also increased substantially between 1971 and 1990, but remained low compared to the industrial sector.

$\checkmark \quad$ Nuclear and hydroelectric power make up an extremely small share of energy consumption in Africa.

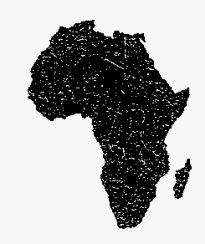




\section{Carbon Emissions by Sector and Fuel Type}

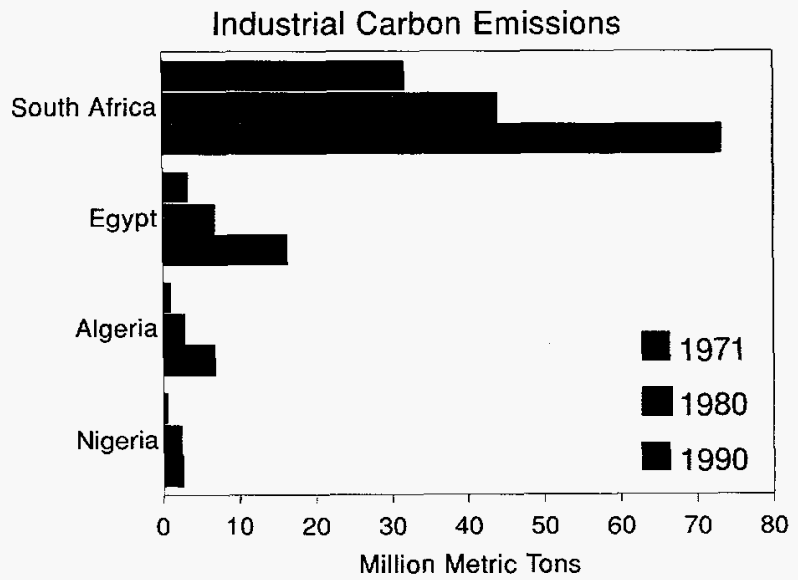

Note: Libyan sectoral data is not available; latest data (1988) used for Algeria.

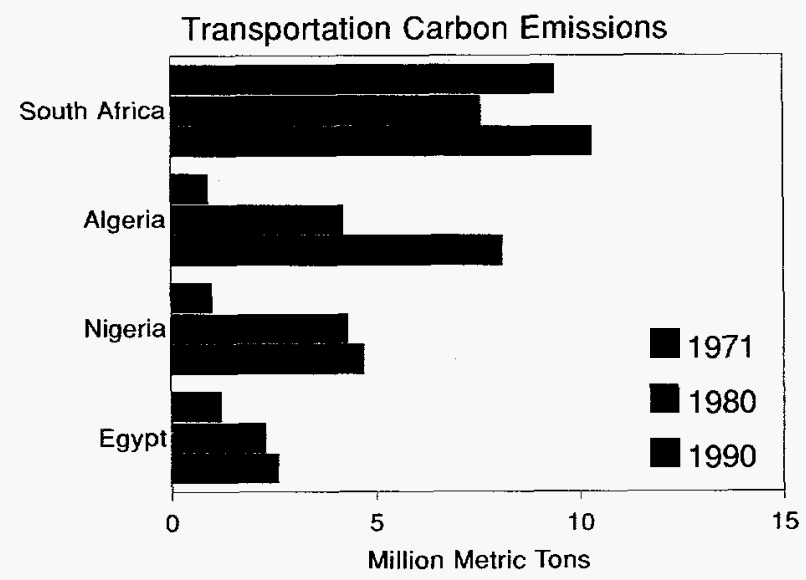

Note: Sectoral data not available for Libya; latest data (1988) used for Algeria.

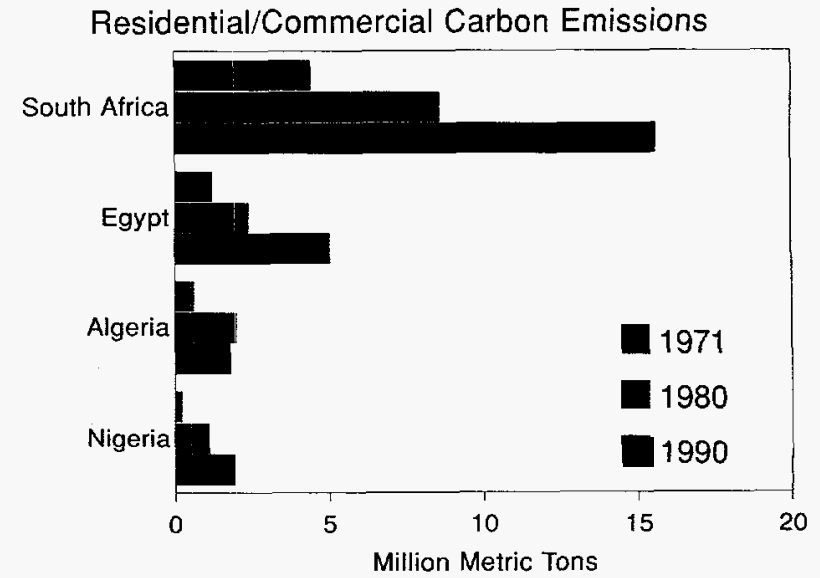

Libyan sectoral data is not available; latest data (1988) used for Algeria.

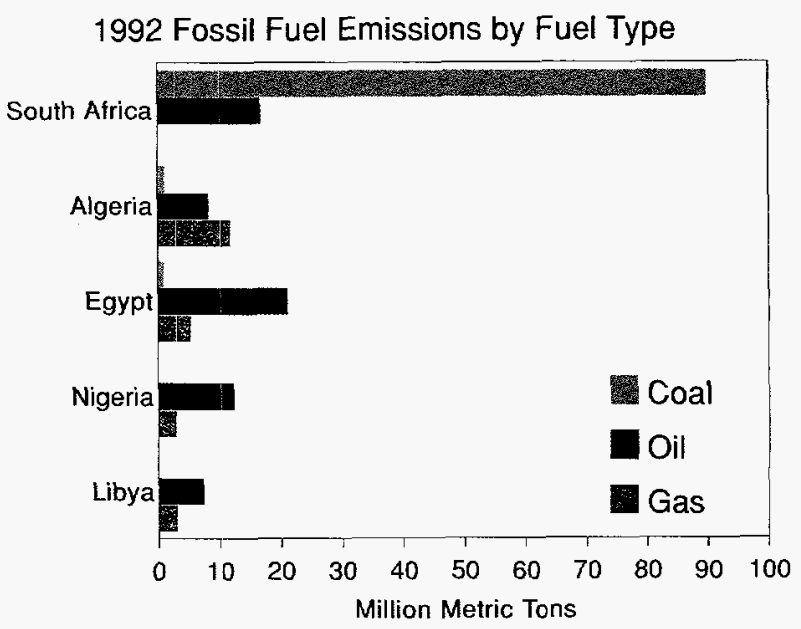

Note: The graphs cannot be directly compared because of differences in scale.

Source: See Appendix p. 58.

$\checkmark$ Africa's industrial sector accounted for the largest share of the region's overall carbon emissions between 1971 and 1990. This was particularly true in South Africa and Egypt.

$\checkmark$ Carbon emissions in Africa's industry rose sharply in the four largest energy consuming nations of Africa between 1971 and 1990, with industrial sector carbon emissions tripling in these countries.

$\checkmark$ However, Africa's industrial carbon emissions remained small relative to other non-OECD regions, with only South Africa ranking among one of the world's largest industrial carbon emitters.

$\checkmark$ Coal accounted for the majority of carbon emissions in South Africa, while oil dominated elsewhere.

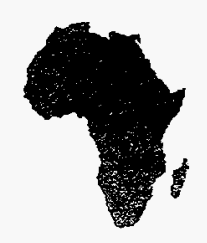




\section{Electricity Overview}
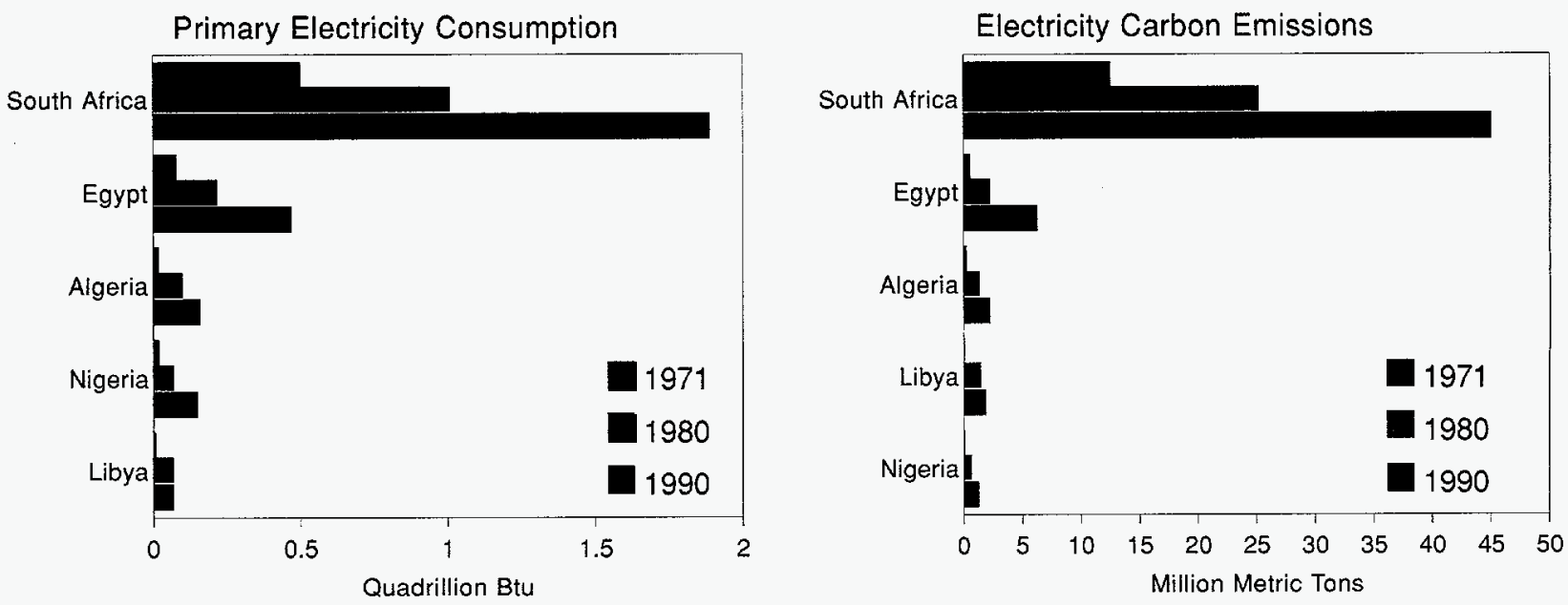

Source: See Appendix p. 58.

$\checkmark$ South Africa consumed the most electricity in Africa between 1971 and 1990. South African electricity also accounted for more carbon emissions than any other African country's electric power sector.

$\checkmark$ Africa consumed small amounts of electricity relative to other non-OECD regions between 1971 and 1990 , although electricity consumption grew rapidly in Africa during the period.

$\checkmark \quad$ Electricity generation accounted for a rapidly growing share of African carbon emissions between 1971 and 1990.

$\checkmark$ South Africa's electricity generation, most of it coal-fired, accounted for 48 percent of the country's carbon emissions in 1990, the highest share of any major world energy consumer. 


\section{Appendix \\ Data Sources}

\section{Non-OECD in a World Context}

Population, Economic Growth, Energy, and Carbon (Page 6)

Sources: The WEFA Group. World Economic Service: Historical Data (Bala Cynwyd, PA, July 1993); The WEFA Group. Ranking of the World's Economies by Size (Bala Cynwyd, PA, March 1994); The World Bank. World Tables 1992 (Washington, D.C.); The International Monetary Fund. International Financial Statistics Yearbook 1992 (Washington, D.C.); Central Intelligence Agency. World Factbook 1993 (Washington, D.C.); Energy Information Administration (EIA). International Energy Annual 1992 (Washington, DC, 1994) and internal data from the International Statistics Branch. Carbon emissions derived from conversion factors in: EIA. Emissions of Greenhouse Gases in the United States, 1985-1990 (DOE/EIA-0573, Washington, DC, September 1993).

Electricity, GDP, Energy Consumption, Carbon Emissions: OECD vs. Non-OECD (P. 7)

Sources: The WEFA Group. World Economic Service: Historical Data (Bala Cynwyd, PA, July 1993); The WEFA Group. Ranking of the World's Economies by Size (Bala Cynwyd, PA, March 1994); The World Bank. World Tables 1992 (Washington, D.C.); The International Monetary Fund. International Financial Statistics Yearbook 1992 (Washington, D.C.); Central Intelligence Agency. World Factbook 1993 (Washington, D.C.); Energy Information Administration (EIA). International Energy Annual 1992 (Washington, DC, 1994) and internal data from the International Statistics Branch. Carbon emissions derived from conversion factors in: EIA. Emissions of Greenhouse Gases in the United States, 1985-1990 (DOE/EIA-0573, Washington, DC, September 1993).

\section{Energy Consumption and Carbon Emissions: OECD vs. Non-OECD (P. 8)}

Sources: Energy Information Administration (EIA). International Energy Annual 1992 (Washington, DC, 1994) and internal data from the International Statistics Branch. Carbon emissions derived from conversion factors in: EIA. Emissions of Greenhouse Gases in the United States, 1985-1990 (DOE/EIA0573, Washington, DC, September 1993).

\section{Non-OECD Regional Comparison}

Population, Economic Growth, Energy and Carbon (P. 10)

Sources: The WEFA Group. World Economic Service: Historical Data (Bala Cynwyd, PA, July 1993); The WEFA Group. Ranking of the World's Economies by Size (Bala Cynwyd, PA, March 1994); The World Bank. World Tables 1992 (Washington, D.C.); The International Monetary Fund. International Financial Statistics Yearbook 1992 (Washington, D.C.); Central Intelligence Agency. World Factbook 1993 (Washington, D.C.); Energy Information Administration (EIA). International Energy Annual 1992 (Washington, DC, 1994) and internal data from the International Statistics Branch. Carbon emissions derived from conversion factors in: EIA. Emissions of Greenhouse Gases in the United States, 1985-1990 (DOE/EIA-0573, Washington, DC, September 1993).

Energy Consumption by Region (P. 11)

Sources: Energy Information Administration (EIA). International Energy Annual 1992 (Washington, DC, 1994) and internal data from the International Statistics Branch.

Energy Consumption by Fuel Type and Energy-Related Carbon Emissions (P. 12)

Sources: Energy Information Administration (EIA). International Energy Annual 1992 (Washington, DC, 1994) and internal data from the International Statistics Branch. Carbon emissions derived from conversion factors in: EIA. Emissions of Greenhouse Gases in the United States, 1985-1990 (DOE/EIA- 
0573, Washington, DC, September 1993).

GDP and Energy Consumption per Capita (P. 13)

Sources: The WEFA Group. World Economic Service: Historical Data (Bala Cynwyd, PA, July 1993); The WEFA Group. Ranking of the World's Economies by Size (Bala Cynwyd, PA, March 1994); The World Bank. World Tables 1992 (Washington, D.C.); The International Monetary Fund. International Financial Statistics Yearbook 1992 (Washington, D.C.); Central Intelligence Agency. World Factbook 1993 (Washington, D.C.); Energy Information Administration (EIA). International Energy Annual 1992 (Washington, DC, 1994) and internal data from the International Statistics Branch. Carbon emissions derived from conversion factors in: EIA. Emissions of Greenhouse Gases in the United States, 1985-1990 (DOE/EIA-0573, Washington, DC, September 1993).

\section{Energy Consumption per Dollar of GDP (P. 14)}

Sources: The WEFA Group. World Economic Service: Historical Data (Bala Cynwyd, PA, July 1993); The WEFA Group. Ranking of the World's Economies by Size (Bala Cynwyd, PA, March 1994); The World Bank. World Tables 1992 (Washington, D.C.); The International Monetary Fund. International Financial Statistics Yearbook 1992 (Washington, D.C.); Central Intelligence Agency. World Factbook 1993 (Washington, D.C.); Energy Information Administration (EIA). International Energy Annual 1992 (Washington, DC, 1994) and internal data from the International Statistics Branch. Carbon emissions derived from conversion factors in: EIA. Emissions of Greenhouse Gases in the United States, 1985-1990 (DOE/EIA-0573, Washington, DC, September 1993).

Energy Use and Carbon Emissions: Non-OECD Rankings, 1992 (P. 15)

Sources: Energy Information Administration (EIA). International Energy Annual 1992 (Washington, DC, 1994) and internal data from the International Statistics Branch. Carbon emissions derived from conversion factors in: EIA. Emissions of Greenhouse Gases in the United States, 1985-1990 (DOE/EIA0573, Washington, DC, September 1993).

Regional Energy Consumption by Sector and Fossil Fuel Share (P. 16)

Sources: Energy Information Administration (EIA). International Energy Annual 1992 (Washington, DC, 1994) and internal data from the International Statistics Branch; The OECD. Energy Balances of NonOECD Countries (Paris, France, 1994).

Electricity Overview (P. 17)

Sources: The OECD. Energy Balances of Non-OECD Countries (Paris, France, 1994). Carbon emissions derived from conversion factors in: EIA. Emissions of Greenhouse Gases in the United States, 1985-1990 (DOE/EIA-0573, Washington, DC, September 1993).

\section{The Former Soviet Union and Eastern Europe}

Energy Consumption by Fuel Type and Energy-Related Carbon Emissions (P. 19)

Sources: Energy Information Administration (EIA). International Energy Annual 1992 (Washington, DC, 1994) and internal data from the International Statistics Branch. Carbon emissions derived from conversion factors in: EIA. Emissions of Greenhouse Gases in the United States, 1985-1990 (DOE/EIA0573, Washington, DC, September 1993).

\section{GDP and Energy Consumption per Capita (P. 20)}

Sources: The WEFA Group. World Economic Service: Historical Data (Bala Cynwyd, PA, July 1993); The WEFA Group. Ranking of the World's Economies by Size (Bala Cynwyd, PA, March 1994); The World Bank. World Tables 1992 (Washington, D.C.); The International Monetary Fund. International Financial Statistics Yearbook 1992 (Washington, D.C.); Central Intelligence Agency. World Factbook 
1993 (Washington, D.C.); Energy Information Administration (EIA). International Energy Annual 1992 (Washington, DC, 1994) and internal data from the International Statistics Branch.

\section{Energy Consumption per Dollar of GDP (P. 21)}

Sources: The WEFA Group. World Economic Service: Historical Data (Bala Cynwyd, PA, July 1993); The WEFA Group. Ranking of the World's Economies by Size (Bala Cynwyd, PA, March 1994); The World Bank. World Tables 1992 (Washington, D.C.); The International Monetary Fund. International Financial Statistics Yearbook 1992 (Washington, D.C.); Central Intelligence Agency. World Factbook 1993 (Washington, D.C.); Energy Information Administration (EIA). International Energy Annual 1992 (Washington, DC, 1994) and internal data from the International Statistics Branch.

\section{Energy Consumption by Sector and Fossil Fuel Share (P. 22)}

Sources: Energy Information Administration (EIA). International Energy Annual 1992 (Washington, DC, 1994) and internal data from the International Statistics Branch; The OECD. Energy Balances of NonOECD Countries (Paris, France, 1994).

\section{Carbon Emissions by Sector and Fuel Type (P. 23)}

Sources: Energy Information Administration (EIA). International Energy Annual 1992 (Washington, DC, 1994) and internal data from the International Statistics Branch; The OECD. Energy Balances of NonOECD Countries (Paris, France, 1994). Carbon emissions derived from conversion factors in: EIA. Emissions of Greenhouse Gases in the United States, 1985-1990 (DOE/EIA-0573, Washington, DC, September 1993).

Electricity Overview (P. 24)

Sources: The OECD. Energy Balances of Non-OECD Countries (Paris, France, 1994). Carbon emissions derived from conversion factors in: EIA. Emissions of Greenhouse Gases in the United States, 1985-1990 (DOE/EIA-0573, Washington, DC, September 1993).

\section{Pacific Rim}

Energy Consumption by Fuel Type and Energy-Related Carbon Emissions (P. 26)

Sources: Energy Information Administration (EIA). International Energy Annual 1992 (Washington, DC, 1994) and internal data from the International Statistics Branch. Carbon emissions derived from conversion factors in: EIA. Emissions of Greenhouse Gases in the United States, 1985-1990 (DOE/EIA0573, Washington, DC, September 1993).

\section{GDP and Energy Consumption per Capita (P. 27)}

Sources: The WEFA Group. World Economic Service: Historical Data (Bala Cynwyd, PA, July 1993); The WEFA Group. Ranking of the World's Economies by Size (Bala Cynwyd, PA, March 1994); The World Bank. World Tables 1992 (Washington, D.C.); The International Monetary Fund. International Financial Statistics Yearbook 1992 (Washington, D.C.); Central Intelligence Agency. World Factbook 1993 (Washington, D.C.); Energy Information Administration (EIA). International Energy Annual 1992 (Washington, DC, 1994) and internal data from the International Statistics Branch.

\section{Energy Consumption per Dollar of GDP (P. 28)}

Sources: The WEFA Group. World Economic Service: Historical Data (Bala Cynwyd, PA, July 1993); The WEFA Group. Ranking of the World's Economies by Size (Bala Cynwyd, PA, March 1994); The World Bank. World Tables 1992 (Washington, D.C.); The International Monetary Fund. International Financial Statistics Yearbook 1992 (Washington, D.C.); Central Intelligence Agency. World Factbook 1993 (Washington, D.C.); Energy Information Administration (EIA). International Energy Annual 1992 (Washington, DC, 1994) and internal data from the International Statistics Branch. 
Energy Consumption by Sector and Fossil Fuel Share (P. 29)

Sources: Energy Information Administration (EIA). International Energy Annual 1992 (Washington, DC, 1994) and internal data from the International Statistics Branch; The OECD. Energy Balances of NonOECD Countries (Paris, France, 1994).

Carbon Emissions by Sector and Fuel Type (P. 30)

Sources: Energy Information Administration (EIA). International Energy Annual 1992 (Washington, DC, 1994) and internal data from the International Statistics Branch; The OECD. Energy Balances of NonOECD Countries (Paris, France, 1994). Carbon emissions derived from conversion factors in: EIA. Emissions of Greenhouse Gases in the United States, 1985-1990 (DOE/EIA-0573, Washington, DC, September 1993).

Electricity Overview (P. 31)

Sources: The OECD. Energy Balances of Non-OECD Countries (Paris, France, 1994). Carbon emissions derived from conversion factors in: EIA. Emissions of Greenhouse Gases in the United States, 1985-1990 (DOE/EIA-0573, Washington, DC, September 1993).

\section{Other Asia}

Energy Consumption by Fuel Type and Energy-Related Carbon Emissions (P. 33)

Sources: Energy Information Administration (EIA). International Energy Annual 1992 (Washington, DC, 1994) and internal data from the International Statistics Branch. Carbon emissions derived from conversion factors in: EIA. Emissions of Greenhouse Gases in the United States, 1985-1990 (DOE/EIA0573, Washington, DC, September 1993).

GDP and Energy Consumption per Capita (P. 34)

Sources: The WEFA Group. World Economic Service: Historical Data (Bala Cynwyd, PA, July 1993); The WEFA Group. Ranking of the World's Economies by Size (Bala Cynwyd, PA, March 1994); The World Bank. World Tables 1992 (Washington, D.C.); The International Monetary Fund. International Financial Statistics Yearbook 1992 (Washington, D.C.); Central Intelligence Agency. World Factbook 1993 (Washington, D.C.); Energy Information Administration (EIA). International Energy Annual 1992 (Washington, DC, 1994) and internal data from the International Statistics Branch.

Energy Consumption per Dollar of GDP (P. 35)

Sources: The WEFA Group. World Economic Service: Historical Data (Bala Cynwyd, PA, July 1993); The WEFA Group. Ranking of the World's Economies by Size (Bala Cynwyd, PA, March 1994); The World Bank. World Tables 1992 (Washington, D.C.); The International Monetary Fund. International Financial Statistics Yearbook 1992 (Washington, D.C.); Central Intelligence Agency. World Factbook 1993 (Washington, D.C.); Energy Information Administration (EIA). International Energy Annual 1992 (Washington, DC, 1994) and internal data from the International Statistics Branch.

Energy Consumption by Sector and Fossil Fuel Share (P. 36)

Sources: Energy Information Administration (EIA). International Energy Annual 1992 (Washington, DC, 1994) and internal data from the International Statistics Branch; The OECD. Energy Balances of NonOECD Countries (Paris, France, 1994).

Carbon Emissions by Sector and Fuel Type (P. 37)

Sources: Energy Information Administration (EIA). International Energy Annual 1992 (Washington, DC, 1994) and internal data from the International Statistics Branch; The OECD. Energy Balances of NonOECD Countries (Paris, France, 1994). Carbon emissions derived from conversion factors in: EIA. Emissions of Greenhouse Gases in the United States, 1985-1990 (DOE/EIA-0573, Washington, DC, September 1993). 
Electricity Overview (P. 38)

Sources: The OECD. Energy Balances of Non-OECD Countries (Paris, France, 1994). Carbon emissions derived from conversion factors in: EIA. Emissions of Greenhouse Gases in the United States, 1985-1990 (DOE/EIA-0573, Washington, DC, September 1993).

\section{Latin America}

Energy Consumption by Fuel Type and Energy-Related Carbon Emissions (P. 40)

Sources: Energy Information Administration (EIA). International Energy Annual 1992 (Washington, DC, 1994) and internal data from the International Statistics Branch. Carbon emissions derived from conversion factors in: EIA. Emissions of Greenhouse Gases in the United States, 1985-1990 (DOE/EIA0573, Washington, DC, September 1993).

\section{GDP and Energy Consumption per Capita (P. 41)}

Sources: The WEFA Group. World Economic Service: Historical Data (Bala Cynwyd, PA, July 1993); The WEFA Group. Ranking of the World's Economies by Size (Bala Cynwyd, PA, March 1994); The World Bank. World Tables 1992 (Washington, D.C.); The International Monetary Fund. International Financial Statistics Yearbook 1992 (Washington, D.C.); Central Intelligence Agency. World Factbook 1993 (Washington, D.C.); Energy Information Administration (EIA). International Energy Annual 1992 (Washington, DC, 1994) and internal data from the International Statistics Branch.

\section{Energy Consumption per Dollar of GDP (P. 42)}

Sources: The WEFA Group. World Economic Service: Historical Data (Bala Cynwyd, PA, July 1993); The WEFA Group. Ranking of the World's Economies by Size (Bala Cynwyd, PA, March 1994); The World Bank. World Tables 1992 (Washington, D.C.); The International Monetary Fund. International Financial Statistics Yearbook 1992 (Washington, D.C.); Central Intelligence Agency. World Factbook 1993 (Washington, D.C.); Energy Information Administration (EIA). International Energy Annual 1992 (Washington, DC, 1994) and internal data from the International Statistics Branch.

Energy Consumption by Sector and Fossil Fuel Share (P. 43)

Sources: Energy Information Administration (EIA). International Energy Annual 1992 (Washington, DC, 1994) and internal data from the International Statistics Branch; The OECD. Energy Balances of NonOECD Countries (Paris, France, 1994).

Carbon Emissions by Sector and Fuel Type (P. 44)

Sources: Energy Information Administration (EIA). International Energy Annual 1992 (Washington, DC, 1994) and internal data from the International Statistics Branch; The OECD. Energy Balances of NonOECD Countries (Paris, France, 1994). Carbon emissions derived from conversion factors in: EIA. Emissions of Greenhouse Gases in the United States, 1985-1990 (DOE/EIA-0573, Washington, DC, September 1993).

Electricity Overview (P. 45)

Sources: The OECD. Energy Balances of Non-OECD Countries (Paris, France, 1994). Carbon emissions derived from conversion factors in: EIA. Emissions of Greenhouse Gases in the United States, 1985-1990 (DOE/EIA-0573, Washington, DC, September 1993).

\section{Africa}

Energy Consumption by Fuel Type and Energy-Related Carbon Emissions (P. 47)

Sources: Energy Information Administration (EIA). International Energy Annual 1992 (Washington, DC, 1994) and internal data from the International Statistics Branch. Carbon emissions derived from conversion factors in: EIA. Emissions of Greenhouse Gases in the United States, 1985-1990 (DOE/EIA0573, Washington, DC, September 1993). 


\section{GDP and Energy Consumption per Capita (P. 48)}

Sources: The WEFA Group. World Economic Service: Historical Data (Bala Cynwyd, PA, July 1993); The WEFA Group. Ranking of the World's Economies by Size (Bala Cynwyd, PA, March 1994); The World Bank. World Tables 1992 (Washington, D.C.); The International Monetary Fund. International Financial Statistics Yearbook 1992 (Washington, D.C.); Central Intelligence Agency. World Factbook 1993 (Washington, D.C.); Energy Information Administration (EIA). International Energy Annual 1992 (Washington, DC, 1994) and internal data from the International Statistics Branch.

\section{Energy Consumption per Dollar of GDP (P. 49)}

Sources: The WEFA Group. World Economic Service: Historical Data (Bala Cynwyd, PA, July 1993); The WEFA Group. Ranking of the World's Economies by Size (Bala Cynwyd, PA, March 1994); The World Bank. World Tables 1992 (Washington, D.C.); The International Monetary Fund. International Financial Statistics Yearbook 1992 (Washington, D.C.); Central Intelligence Agency. World Factbook 1993 (Washington, D.C.); Energy Information Administration (EIA). International Energy Annual 1992 (Washington, DC, 1994) and internal data from the International Statistics Branch.

\section{Energy Consumption by Sector and Fossil Fuel Share (P. 50)}

Sources: Energy Information Administration (EIA). International Energy Annual 1992 (Washington, DC, 1994) and internal data from the International Statistics Branch; The OECD. Energy Balances of NonOECD Countries (Paris, France, 1994).

Carbon Emissions by Sector and Fuel Type (P. 51)

Sources: Energy Information Administration (EIA). International Energy Annual 1992 (Washington, DC, 1994) and internal data from the International Statistics Branch; The OECD. Energy Balances of NonOECD Countries (Paris, France, 1994). Carbon emissions derived from conversion factors in: EIA. Emissions of Greenhouse Gases in the United States, 1985-1990 (DOE/EIA-0573, Washington, DC, September 1993).

\section{Electricity Overview (P. 52)}

Sources: The OECD. Energy Balances of Non-OECD Countries (Paris, France, 1994). Carbon emissions derived from conversion factors in: EIA. Emissions of Greenhouse Gases in the United States, 1985-1990 (DOE/EIA-0573, Washington, DC, September 1993). 


\section{End Notes}

1. The energy data in this report are limited to commercial energy (oil, gas, coal, electricity). Consequently, both energy consumption and carbon emissions from energy consumption are understated because they do not account for consumption of traditional fuels (fuelwood, dung, peat, etc.). The degree of underestimation is unknown for each region, but is probably greatest in Africa, Other Asia, and Pacific Rim, where usage of traditional fuels is highest.

2. See EIA's reports, Emissions of Greenhouse Gases in the United States, 1985-1990 (DOE/EIA-0573, Washington, DC, September 1993), and Emissions of Greenhouse Gases in the United States, 19871992 (DOE/EIA-0573(94), Washington, DC, October 1994).

3. Members of the OECD in 1993 included: Australia; Austria; Belgium; Canada; Denmark; Finland; France; Germany; Greece; Iceland; Ireland; Italy; Japan; Luxembourg; Netherlands; New Zealand; Norway; Portugal; Spain; Sweden; Switzerland; Turkey; United Kingdom; and the United States. All other countries of the world are defined as non-OECD. These include the current and former centrally-planned economies and other developing countries. Mexico, which was admitted to the OECD in 1994, is included as a non-OECD country for the 1970-1992 time period. East Germany is included as part of Germany, an OECD member, throughout the report.

4. For this report, members of each region are as follows:

Former Soviet Union and Eastern Europe: Albania, Bulgaria, the former Czechoslovakia, Hungary, Poland, Romania, and the former Soviet Union. East Germany is not included here, but is accounted for as part of Germany, an OECD country.

Pacific Rim: Every Asian country bordering the Pacific Ocean (and Laos and Mongolia) except OECD countries (Australia, Japan, New Zealand) and the Former Soviet Union. These include: American Samoa, Brunei, China, Cook Islands, Fiji, French Polynesia, Guam, Hong Kong, Indonesia, Kampuchea (Cambodia), Kirabatia (Gilbert Islands), Korea (North), Korea (South), Macau, Malaysia, Mongolia, New Caledonia, Nieu, Papua New Guinea, Philippines, Western Samoa, Singapore, Solomon Islands, Taiwan, Thailand, Tonga, Tuvalu, U.S. Pacific Islands, Vanatu (New Hebrides), Vietnam, and Wake Island.

Other Asia: Every country in the Middle East and South Asia. These include: Bahrain, Cyprus, Iran, Iraq, Israel, Jordan, Kuwait, Lebanon, Oman, Qatar, Saudi Arabia, Syria, the United Arab Emirates (U.A.E.), and Yemen in the Middle East; and Afghanistan, Bangladesh, Bhutan, India, Laos, Maldives, Myanmar, Nepal, Pakistan, and Sri Lanka of South Asia. Turkey is part of the OECD and is not included here.

Latin America: Every country in the Western Hemisphere except Canada and the United States.

Africa: Every country in the African continent.

5. Complete annual data are not always available for all years for all countries. This is particularly true for sectoral data. The latest available data is included for each graph.

6. According to the OECD National Accounts, Vol. 1: 1960-1991, GDP is defined as equal to "the total of the gross expenditure on the final uses of the domestic supply of goods and services...less imports 
of goods and services." Gross National Product, or GNP, is substituted for GDP in this report when GDP statistics are not available. GNP is the same as GDP, except that it does not exclude imports of goods and services.

7. Carbon emissions are estimated by using carbon emissions factors derived from EIA's report Emissions of Greenhouse Gases in the United States, 1985-1990 (DOE/EIA-0573, Washington, DC, September 1993). Fossil energy (oil, gas, coal) consumption data were converted from quadrillion Btu of energy to million metric tons of carbon by multiplying them by the following factors: oil (20), natural gas (14.54), and coal (25.45). Metric tons are equivalent to 1.102 short (2,000 pounds) tons.

Tons of carbon emissions can be converted into tons of carbon dioxide emissions by multiplying by 3.6667. This assumes that all carbon emissions are in the form of carbon dioxide. This assumption results in a slight overestimate, because a small percentage of carbon is emitted in the form of ash, carbon monoxide, and volatile organic compounds. The degree of overestimation various from about 1 percent from stationary sources such as electricity generation to a few percent for other sectors such as transportation. 


\section{Abbreviations and Acronyms}

Btu

British thermal unit (the amount of energy required to raise the temperature of 1 pound of water 1 degree fahrenheit; 8 gallons of gasoline contain 1 million Btu)

FSU Former Soviet Union

GDP

Gross domestic product

E/GDP Ratio of energy consumption to gross domestic product

G-7 Group of Seven (Canada, France, Italy, Japan, Germany, United Kingdom, United States)

OECD Organization for Economic Cooperation and Development (for list of countries in OECD, see Appendix, endnote \#3)

Non-OECD All countries that are not members of the OECD (for list of countries by region that are not in the OECD, see Appendix, endnote \#4)

U.A.E. United Arab Emirates 